\title{
Epidemiology of and Risk Factors for Coronavirus Infection in Health Care Workers
}

\section{A Living Rapid Review}

\author{
Roger Chou, MD; Tracy Dana, MLS; David I. Buckley, MD, MPH; Shelley Selph, MD, MPH; Rongwei Fu, PhD; \\ and Annette M. Totten, PhD
}

Background: Health care workers (HCWs) are at risk for severe acute respiratory syndrome-coronavirus-2 (SARS-CoV-2) infection.

Purpose: To examine the burden of SARS-CoV-2, SARS-CoV-1, and Middle Eastern respiratory syndrome (MERS)-CoV on HCWs and risk factors for infection, using rapid and living review methods.

Data Sources: Multiple electronic databases including the WHO Database of Publications on Coronavirus Disease and medRxiv preprint server (2003 through 27 March 2020, with ongoing surveillance through 24 April 2020), and reference lists.

Study Selection: Studies published in any language reporting incidence of or outcomes associated with coronavirus infections in HCWs and studies on the association between risk factors (demographic characteristics, role, exposures, environmental and administrative factors, and personal protective equipment [PPE] use) and HCW infections. New evidence will be incorporated on an ongoing basis by using living review methods.

Data Extraction: One reviewer abstracted data and assessed methodological limitations; verification was done by a second reviewer.

Data Synthesis: 64 studies met inclusion criteria; 43 studies addressed burden of HCW infections (15 on SARS-CoV-2), and 34 studies addressed risk factors ( 3 on SARS-CoV-2). Health care workers accounted for a significant proportion of coronavirus in- fections and may experience particularly high infection incidence after unprotected exposures. Illness severity was lower than in non-HCWs. Depression, anxiety, and psychological distress were common in $\mathrm{HCW}$ s during the coronavirus disease 2019 outbreak. The strongest evidence on risk factors was on PPE use and decreased infection risk. The association was most consistent for masks but was also observed for gloves, gowns, eye protection, and handwashing; evidence suggested a doseresponse relationship. No study evaluated PPE reuse. Certain exposures (such as involvement in intubations, direct patient contact, or contact with bodily secretions) were associated with increased infection risk. Infection control training was associated with decreased risk.

Limitation: There were few studies on risk factors for SARSCoV-2, the studies had methodological limitations, and streamlined rapid review methods were used.

Conclusion: Health care workers experience significant burdens from coronavirus infections, including SARS-CoV-2. Use of PPE and infection control training are associated with decreased infection risk, and certain exposures are associated with increased risk.

Primary Funding Source: World Health Organization.

Ann Intern Med. doi:10.7326/M20-1632

Annals.org

For author, article, and disclosure information, see end of text.

This article was published at Annals.org on 5 May 2020.
A cluster of pneumonia cases in Wuhan, China, was first reported to the World Health Organization (WHO) on 31 December 2019 (1). The cause was identified as the novel coronavirus SARS-CoV-2 (2-4), and the disease was named "coronavirus disease 2019" (COVID-2019) (5).

Health care workers (HCWs) are at risk for SARSCoV-2 infection (6), and reports have described COVID-19 cases in HCWs since early in the outbreak (7). Preventing HCW infections is important for reducing morbidity and potential mortality, maintaining health system capacity, and reducing secondary transmission $(8,9)$.

This rapid review summarizes the evidence on the burden of and risk factors for SARS-CoV-2 infections in $\mathrm{HCWs}$. The report will be used by WHO to inform the development of evidence-based guidance. Because evidence is limited on SARS-CoV-2, this review also includes 2 coronaviruses associated with earlier pneumonia outbreaks: SARS-CoV-1 (causing severe acute respiratory syndrome [SARS-1]) and MERS-CoV (causing Middle East respiratory syndrome [MERS]).

\section{Methods}

Detailed methods are available in the full report (10). The key questions were developed by WHO with input from the review authors.

Key Question 1. What is the burden of SARSCoV-2, SARS-CoV-1, and MERS-CoV on HCWs and how do burdens vary according to age, sex, and presence of comorbidities?

Key Question 2. What are the risk factors for HCW infections with SARS-CoV-2, SARS-CoV-1, and MERSCoV?

Key Question 3. What are the risk factors for household transmission of SARS-CoV-2, SARS-CoV-1, and MERS-CoV from HCWs?

\section{See also: \\ Editorial comment 1 \\ Web-Only \\ CME/MOC activity}


Because of the urgent and ongoing need to support WHO's pandemic response, a rapid, living review approach was used (11). Rapid reviews utilize streamlined systematic review processes. For this review, modified methods included 1) protocol not posted to a systematic review registry; 2) a gray literature search limited to 1 website; 3 ) dual review of $25 \%$ of abstracts; 4) critical appraisal not conducted using a formal instrument; and 5) single-reviewer assessment of study limitations and data abstraction, with second reviewer verification. Living reviews use methods for continual updating, as new evidence becomes available (12).

\section{Data Sources and Searches}

A medical librarian searched PubMed, MEDLINE, and Elsevier Embase (from 2003 through 27 March 2020). Searches had no language restrictions. Search strategies are shown in Appendix Table 1 (available at Annals.org). We also searched the WHO Database on Coronavirus Disease (13) and the medRxiv preprint server (14) and reviewed reference lists. Daily MEDLINE surveillance and weekly surveillance on EMBASE, the WHO Database on Coronavirus Disease, and the medRxiv server is ongoing; this article includes surveillance through 24 April 2020.

\section{Study Selection}

Studies were selected by using predefined criteria (Appendix Table 2, available at Annals.org). The population was HCWs at risk for or with SARS-CoV-2, SARSCoV-1, or MERS-CoV infection. For key question 1, for SARS-CoV-2, we included cohort studies and case series on incidence and severity of infection, mortality, morbidity (including mental health outcomes), and effects on family members and contacts. For SARS-CoV-1 and MERS-CoV, inclusion was restricted to cohort studies on incidence, infection severity, and mortality. For key question 2, potential risk factors were demographic characteristics, exposure history, administrative factors, health care setting/environmental factors, HCW health, and infection control and prevention factors. We included studies that reported risk estimates or infection incidence stratified by risk factor.

One investigator reviewed each citation for potential full-text review. A second investigator reviewed a $25 \%$ random sample of citations; disagreements were resolved through consensus. One investigator reviewed each full-text article for inclusion, and a second verified exclusion decisions. We included non-peer-reviewed articles for SARS-CoV-2 because the peer-reviewed literature was sparse. Chinese-language articles were translated by a review team member who was a native speaker.

\section{Data Extraction}

One investigator extracted study data into standardized tables and a second verified data: study author, year, setting (country, health care setting, dates), population characteristics (sample size, age, sex, HCW role/position, number of cases), and results. For key question 2, odds ratios were calculated if necessary and the data were available.

\section{Quality Assessment}

We did not perform formal risk for bias assessment. Instead, we noted key limitations of each study, such as potential recall, selection, or participation bias; issues regarding evaluation of outcomes and analytic methods; and confounding $(15,16)$.

\section{Data Synthesis and Analysis}

Results were synthesized narratively. For key question 2, unadjusted and adjusted risk estimates were presented. Quantitative synthesis was not possible owing to methodological limitations; study design variability; and heterogeneity in populations, comparisons, and analytic methods.

\section{Living Review}

Surveillance for new studies is ongoing, and study selection and quality assessment will follow the same processes described. New evidence that does not substantively change review conclusions will be briefly summarized on a monthly basis; a major update will be performed when new evidence changes the nature or strength of the conclusions.

\section{Role of the Funding Source}

The study was funded by the WHO. Staff at the WHO developed the key questions and review scope but did not have any role in the selection, assessment, or synthesis of evidence. The WHO was not involved in the decision to submit this article for publication.

\section{RESUlts}

Sixty-four studies met inclusion criteria (17-48-4980). The Appendix Figure (available at Annals.org) summarizes the study selection process and number of included studies, by key question and coronavirus type.

\section{Key Question 1: Burden of Coronavirus Infections on HCWs SARS-CoV-2}

One cohort study (61), 9 cross-sectional studies $(28,36,39,40,46,51,59,79,80)$ and 5 case series $(47$, $48,53,67,68)$ reported on the burden of SARS-CoV-2 in HCWs (Appendix Table 3, available at Annals.org).

Two non-peer-reviewed, retrospective cohort studies reported the proportion of exposed HCWs with polymerase chain reaction (PCR)-confirmed SARSCoV-2 infection $(39,61)$. One study evaluated 1353 $\mathrm{HCW}$ in the Netherlands with recent fever or mild respiratory symptoms. Infection with SARS-CoV-2 was present in $6.4 \%$ (86 of 1353) of the HCWs; $91.9 \%$ (79 of 86) of infections met the COVID-19 case definition. Two $\mathrm{HCWs}$ (3.7\% [2 of 86]) were hospitalized, with no critical cases or deaths. A second, smaller study of 72 exposed HCWs with acute symptoms in Wuhan, China, reported a COVID-19 incidence of 38.9\% (61).

Health care workers accounted for 3.8\% (1716 cases) of 44672 cases of COVID-19 (PCR-confirmed) diagnosed in China through 11 February 2020 (67). The proportion of HCW cases classified as severe or critical was $15 \%$ (247 of 1608), and the case-fatality rate was $0.3 \%$ ( 5 of 1716). Health care workers accounted 
for a higher proportion of cases from 11 to 20 January (5.7\%), early in the outbreak when case numbers were increasing sharply. The proportion of cases that were severe or critical was highest from 1 to 10 January (45\% [9 of 20]) and lowest after 1 February (8.7\% [28 of 322]).

Another non-peer-reviewed study evaluated a large series of 25961 patients with PCR-confirmed COVID-19 diagnosed in Wuhan, China, through 18 February 2020 (68). Health care workers accounted for $5.1 \%$ (1316 of 25961$)$ of cases. The overall estimated COVID-19 incidence, using epidemiologic data for denominators, was higher in HCWs than the general population (144.7 [95\% Cl, 137.0 to 152.8$]$ vs. $41.7[\mathrm{Cl} 41.2$ to 42.2 ] per $10^{6}$ people) (Appendix Table 3).

Three case series reported outcomes of COVID-19 infections in HCWs $(47,48,53)$. Two separate series (50 and $64 \mathrm{HCWs}$ ) reported on infected HCWs in Wuhan, China $(47,48)$. The average age $(35$ years) and proportion female ( $65 \%)$ were similar. In one study, one third of cases were physicians and two thirds were nurses; this was reversed in the other study. There were no deaths. In one study, $1.6 \%$ (1 of 64) of HCWs had severe illness not requiring mechanical ventilation (47). In the other study, $13.3 \%$ (4 of 30 ) met criteria for severe pneumonia and received noninvasive ventilation or nasal high-flow oxygen (48). A limitation of the studies is that $20 \%$ and $47 \%$ of cases remained hospitalized at outcome assessment. In addition, in 1 study, few cases (25\% [7 of 30]) were PCR-confirmed (48). The third study found that $29 \%$ (50 of 167) of cases in a U.S. long-term care facility were HCWs (53). The median age was 43.5 years, and $76 \%$ were female. Six percent (3 of 50) of HCWs were hospitalized, with no deaths.

Seven cross-sectional studies (16 $630 \mathrm{HCWs)} \mathrm{eval-}$ uated the mental health or sleep quality of HCWs in China during the COVID-2019 outbreak $(28,36,40,46$, $51,59,80)$. The proportion of HCWs meeting clinically relevant (that is, moderate or severe) thresholds was $14 \%$ to $15 \%$ for depression $(40,80), 12 \%$ to $24 \%$ for anxiety $(40,46,80), 30 \%$ to $39 \%$ for psychological distress $(28,40,80), 8 \%$ to $60 \%$ for sleep issues $(40,59)$, and $29 \%$ (36) for a composite mental health outcome. Female sex $(28,40,80)$ and direct contact with cases $(40,46,51,80)$ were associated with increased likelihood of mental health issues; effect of $\mathrm{HCW}$ role on risk was inconsistent $(28,36,80)$. Methodological limitations included no baseline symptom information, no non-HCW comparison groups, and not controlling for work exposures. One cross-sectional study (843 persons) found a high prevalence of anxiety (34\%) and psychological distress (29\%) in family members of HCWs (79).

No study reported the social or economic effects of SARS-CoV-2 infection in HCWs or the incidence of $\mathrm{HCW}$ transmission to close contacts.

\section{SARS-CoV-1}

Fourteen cohort studies $(25,30,32-35,43,45,50$, $57,60,64,69,74), 1$ cross-sectional study (27), and 1 case series (44) reported on the burden of SARS-CoV-1 in HCWs (Appendix Table 3). We also included WHO data (81).

The prevalence of SARS-CoV-1 seropositivity in exposed or potentially exposed $\mathrm{HCW}$ ranged from $0.3 \%$ to $40 \%$ in 6 studies $(25,27,33,57,60,69)$, and SARS-1 incidence ranged from $1.2 \%$ to $29.4 \%$ in 14 studies $(25$, $30,32-35,43,45,50,57,60,64,69,74)$. The highest SARS-1 incidence (29.4\%) occurred in a large outbreak in Vietnam in a hospital without an isolation ward (57). In addition, infection control measures were not initiated owing to unawareness of the index SARS-1 case. Another study reporting high incidence focused on critical care nurses in Canada who cared for patients with SARS-1 with unstandardized PPE use, often before knowing patients' infection status (50).

Health care workers accounted for 21\% (1706 of 8096) of all SARS-1 cases reported to WHO (Appendix Table 4, available at Annals.org). Among countries with at least 50 cases, HCWs accounted for 19\% (China) to $57 \%$ (Vietnam). Among all $(n=1755)$ SARS- 1 cases from Hong Kong, the case-fatality rate in HCWs was $2.0 \%$ (8 of 405), compared with $21.8 \%$ (294 of 1350) in non-HCWs (adjusted OR, 0.3 [Cl, 0.1 to 0.7]) (Appendix Table 3) (44).

\section{MERS-CoV}

Seven cohort studies $(18,19,21,37,38,63,71), 4$ case series $(17,20,22,29)$, and 1 cross-sectional study (54) reported on the burden of MERS in HCWs (Appendix Table 3). We also utilized WHO data (82).

In 3 studies with at least $500 \mathrm{HCWs}(3311 \mathrm{HCWs}$ in total), the proportion with MERS-CoV infection ranged from $1.12 \%$ to $2.0 \%(21,37,54)$. In 5 smaller studies (9 to $283 \mathrm{HCWs}$ ), the proportion ranged from $0 \%$ to $7.1 \%$ $(18,19,38,63,71)$.

As of December 2019, HCWs accounted for $19.1 \%$ (402 of 2106) of laboratory-confirmed cases of MERS in Saudi Arabia, which accounts for $84 \%$ of cases (Appendix Table 4) (82). Globally, among the 651 MERS cases diagnosed in July to December, $14 \%$ to $18 \%$ were HCWs in 2014 and 2015 and 0 to 4\% in 2018 and 2019.

An analysis of all cases of MERS in HCWs reported to $\mathrm{WHO}$ found an overall case-fatality rate of 5.8\% (24 of 415); excluding primary cases, mortality was slightly lower (4.7\%) (29). These figures are lower than the overall MERS case-fatality rate (34.4\%) (82). Two smaller case series (166 and $105 \mathrm{HCWs)} \mathrm{reported} \mathrm{HCW} \mathrm{case-}$ fatality rates of $3.0 \%$ and $16 \%(17,20)$. Studies that directly compared MERS mortality in HCWs versus non$\mathrm{HCW}$ also reported lower mortality risk in $\mathrm{HCWs}(17$, $20,22)$. In the largest analysis (2260 HCWs), the adjusted OR was $0.07(\mathrm{Cl}, 0.001$ to 0.35$)$ (22). Factors associated with increased mortality risk in $\mathrm{HCWs}$ are older age and presence of comorbid conditions (22, 29).

\section{Key Question 2: Risk Factors for Coronavirus Infection in HCWs SARS-CoV-2}

Three retrospective cohort studies evaluated risk factors for COVID-19 in exposed HCWs (Appendix Ta- 
ble 5, available at Annals.org) (55, 61, 70). One study evaluated risk factors for COVID-19 in 72 exposed $\mathrm{HCW}$ (clinicians and nurses) in Wuhan, China, who had acute symptoms (61). The median age was 31 years, and $69 \%$ of HCWs were female; PCR-confirmed COVID-19 occurred in 38.9\% (28 of 72 HCWs). Risk factors were working in a high risk versus general department (relative risk [RR], $2.13[\mathrm{Cl}, 1.45$ to 3.95$]$ ), suboptimal handwashing before or after patient contact (RR, $3.10[\mathrm{Cl}, 1.43$ to 6.73$]$ and $2.82[\mathrm{Cl}, 1.11$ to 7.18$]$, respectively), longer work hours (log-rank $P=0.02)$, and improper PPE use (RR, $2.82[\mathrm{Cl}, 1.11$ to 7.18$])$. Such procedures as endotracheal tube removal, cardiopulmonary resuscitation, fiberoptic bronchoscopy, and sputum suction were not associated with increased risk. Having a diagnosed family member was associated with increased risk (RR, $2.76[\mathrm{Cl} 2.02$ to 3.77]), suggesting that some HCW infections may have been acquired outside the hospital. The study was susceptible to recall bias, it was unclear whether risk estimates were adjusted, and some estimates were imprecise.

Another study evaluated $41 \mathrm{HCWs}$ exposed to a patient with COVID-19 and an aerosol-generating procedure for 10 or more minutes at a distance of 2 meters or less (55). Eighty-five percent of HCWs used a surgical mask, and 15\% used an N95 respirator. No COVID-19 cases occurred; therefore, it was not possible to draw conclusions about effects of mask type. One other study reported a strong association between N95 respirator use and decreased COVID-19 risk, but had serious limitations (70). Mask use was based on the department worked (not on individual use), departments varied in other infection control measures (such as handwashing), and estimates were very imprecise.

\section{SARS-CoV-1}

Seventeen cohort studies $(23,25,30,32-35,43,45$, $50,57,60,64,69,72,75,77), 11$ case-control studies $(26,41,49,52,56,58,62,65,66,76)$, and one crosssectional study (27) evaluated risk factors for SARSCoV-1 infection in HCWs (Appendix Table 5). Seven studies evaluated risk for SARS-CoV-1 seropositivity, not necessarily meeting the SARS-1 case definition (25$27,33,60,69,72)$. The remainder evaluated risk for SARS-1 meeting the case definition, usually with laboratory confirmation. Ten studies reported adjusted risk estimates from multivariate models $(26,41,49,52,57$, $58,60,66,76,78)$. Of these, 2 studies evaluated correlations between risk factors (for example, between use of different types of PPE) to inform variable selection for model building $(49,76)$. All studies except for 1 (32) were retrospective. The studies were limited in their ability to measure and control for the amount and intensity of exposures.

Age and Sex. Six studies indicated no association between sex and risk for SARS-CoV-1 infection in HCWs (Appendix Table 6, available at Annals.org) (27, 56, 60, $66,69)$. One study found no association between age and risk for SARS-CoV-1 infections after controlling for other factors (adjusted OR, 0.97 [Cl, 0.90 to 1.03]) (57).
Five other studies that did not control for confounders also found no association between age and risk for SARS-CoV-1 infection $(27,56,60,66)$.

Professional Profile. Twelve studies reported SARSCoV-2 infection incidence by HCW role (Appendix Table 6$)(25,27,30,32,34,43,52,56,57,60,69)$. Infections occurred in HCWs across various clinical and nonclinical (including nonpatient contact) roles. There was no consistent difference in risk between nurses and physicians, the most commonly evaluated HCW roles, based on 12 studies $(25,27,30,32,34,43,45,52,56$, $57,60,69)$. There were too few studies and cases to determine risks for other HCW roles relative to nurses and physicians.

Exposure History. Exposure during endotracheal intubation was strongly and consistently associated with increased risk for HCW SARS-CoV-1 infections in 6 studies (Table 1) $(26,30,49,50,58,60)$. Of these, 4 studies found exposure during endotracheal intubation to be independently associated with risk $(26,30,58$, 60 ). One study (50) found oxygen mask manipulation to be associated with increased risk for infection in a univariate analysis, but 2 other studies $(60,66)$ found that oxygen mask manipulation or oxygen administration were not independent predictors. Few studies evaluated risks associated with other procedures involving oxygen administration, such as noninvasive positive-pressure ventilation $(30,50,60)$, high-frequency oscillatory ventilation (30), nebulizer treatment $(50,60)$, manual ventilation (50), high-flow oxygen (60), or mechanical ventilation (60), and estimates were often imprecise. Other procedures associated with increased risk but only evaluated in 1 or 2 studies each were electrocardiography $(50,60)$, chest compressions $(49,60)$, and suctioning before intubation (50). In most studies, direct patient contact was associated with increased risk compared with less direct contact, though some inconsistency was present (26, $33,41,49,57,58,62,66,72)$. Other exposures associated with increased risk for infections in $\mathrm{HCW}$ s were exposure of eyes or mucous membranes to patient bodily fluids $(60,64)$, contact with more severely ill patients (60), contact with a "super spreading" patient (26), closer proximity to infected patients $(58,62,64$, $75)$, and contact with respiratory secretions $(49,52)$. Evidence on the association between duration of contact with patients and risk for infection was inconsistent (52, $60,64,66$ ).

Administrative Factors. One study found administrative measures (having a crisis response team, exclusion of visitors, or provision of administrative support) and PPE use policies (requiring N95 respirator in the emergency department, within certain hospital zones, or on entering the hospital) were not associated with risk for HCW infections (Appendix Table 7, available at Annals.org) (76). Another study (with the same lead author) found a lower incidence of HCW infections in a hospital in which an integrated infection control strategy was implemented compared with 86 control hospitals, but did not control for use of infection control measures or degree of SARS-1 exposure (77).

Health Care Setting and Environmental Factors. One study of hospitals found installation of a fever screen station outside of the emergency department and alco- 


\begin{tabular}{|c|c|c|c|c|c|}
\hline $\begin{array}{l}\text { Author, Year } \\
\text { (Reference) }\end{array}$ & Intubation & $\begin{array}{l}\text { Directness of } \\
\text { Contact }\end{array}$ & $\begin{array}{l}\text { Oxygen } \\
\text { Administration and } \\
\text { Related Exposures }\end{array}$ & $\begin{array}{l}\text { Number or Duration of } \\
\text { Contacts and Proximity } \\
\text { to Patient }\end{array}$ & Other Exposures \\
\hline
\end{tabular}

\section{SARS-CoV-2}

Ran et al,

$2020(61)$

Endotracheal tube

removal: RR, 0.63 (95\%

$\mathrm{Cl}, 0.06-7.08)$

\section{CPR: RR, $0.63(95 \% \mathrm{Cl}$ $0.06-7.08)$ \\ Fiberoptic \\ bronchoscopy: RR, \\ $0.63(95 \% \mathrm{Cl}$ \\ $0.06-7.08)$ \\ Caring for "super spreading" patient vs. not: adjusted $O R$ $3.57(95 \% \mathrm{Cl}$, \\ 1.94-6.57) \\ Performing tracheostomy (yes vs. no): $O R, 4.15$ (95\% Cl, \\ 1.50-11.50)t}

\section{SARS-CoV-1}

adjusted $O R, 2.76$
Chen et al,

2009 (26)

\begin{tabular}{|c|c|}
\hline $\begin{array}{l}\text { Fowler et al, } \\
2004 \text { (30) }\end{array}$ & $\begin{array}{l}\text { Any involvement in } \\
\text { intubation vs. no } \\
\text { involvement: adjusted } \\
\text { OR, 13.29 (95\% Cl, } \\
2.99-59.04)\end{array}$ \\
\hline
\end{tabular}

Performing endotracheal

intubation vs. not:

(95\% Cl, 1.16-6.53)

Avoiding face to

face contact

(reference

never)

Sometimes:

adjusted OR,

$0.67(95 \% \mathrm{Cl}$

0.36-1.24)

Often: adjusted

$\mathrm{OR}, 0.30$

(95\% Cl,

0.10-0.90)

Every time:

adjusted $O R$,

$0.30(95 \% \mathrm{Cl}$,

0.15-0.60)

$-$

(2)

Ho et al,

2004 (33)

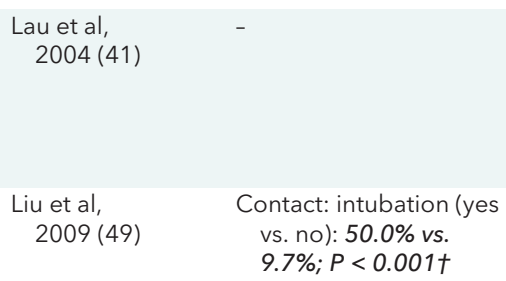
2009 (49)

Contact: intubation (yes vs. no): $50.0 \%$ vs. 9.7\%; $P<0.001+$

Exposure only

vs. direct

contact: RR,

$2.40(95 \% \mathrm{Cl}$,

0.64-9.00)

Direct contact with SARS-1 patients (yes vs. no): OR, $0.57(95 \% \mathrm{Cl}$, 0.28-1.14)†

Contact:

physical

contact (yes

vs. no): $11.3 \%$

vs. $10.3 \% ; P=$

$0.75 \dagger$$$
-
$$
Patient treated with noninvasive positive-pressure vs. conventional ventilation: adjusted OR, $2.33(95 \% \mathrm{Cl}$, 0.25-21.76)
Patient treated with high-frequency oscillatory vs. conventional ventilation: adjusted OR, 0.74 (95\% Cl,
0.11-4.92)$$
\text { 2) }
$$ 


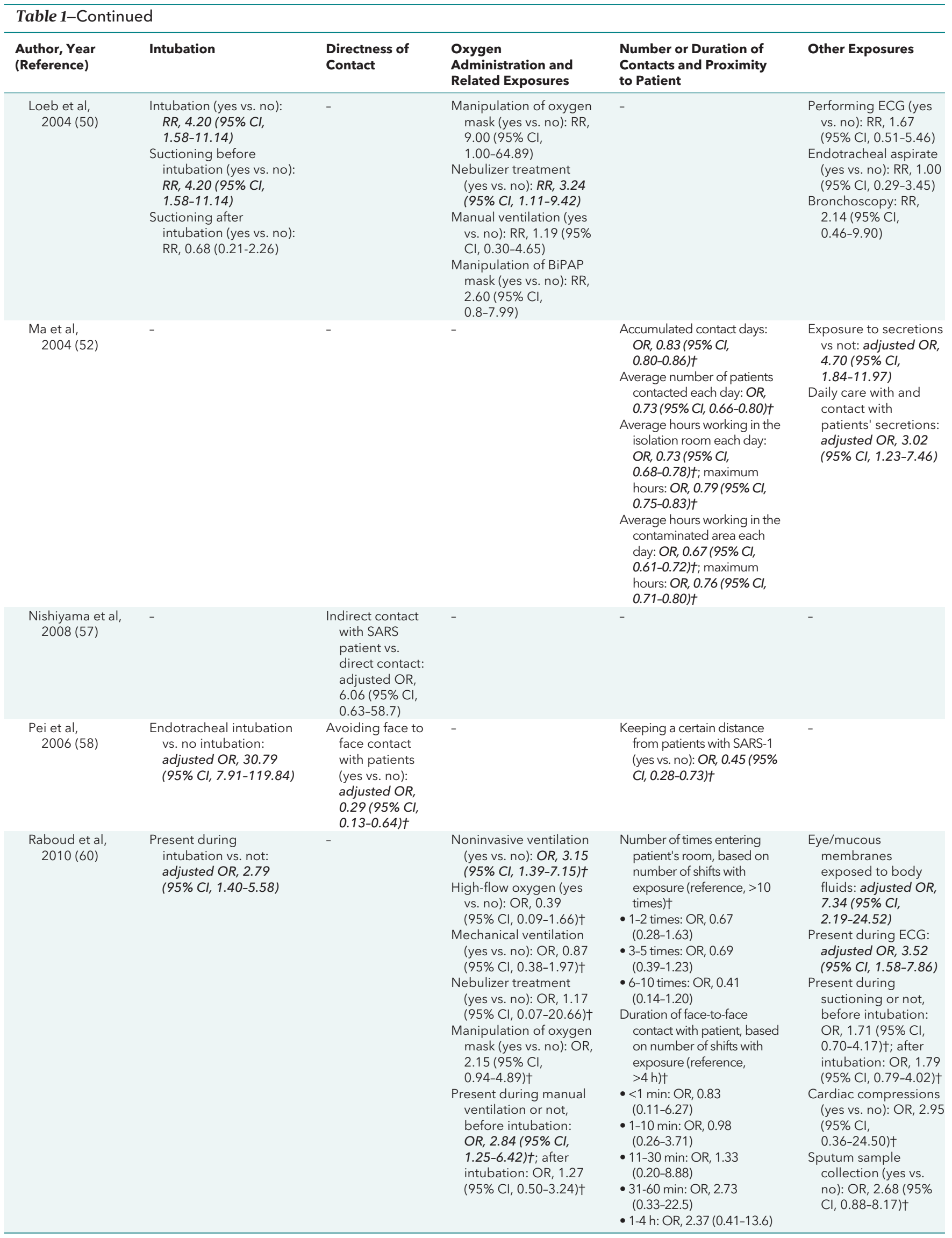




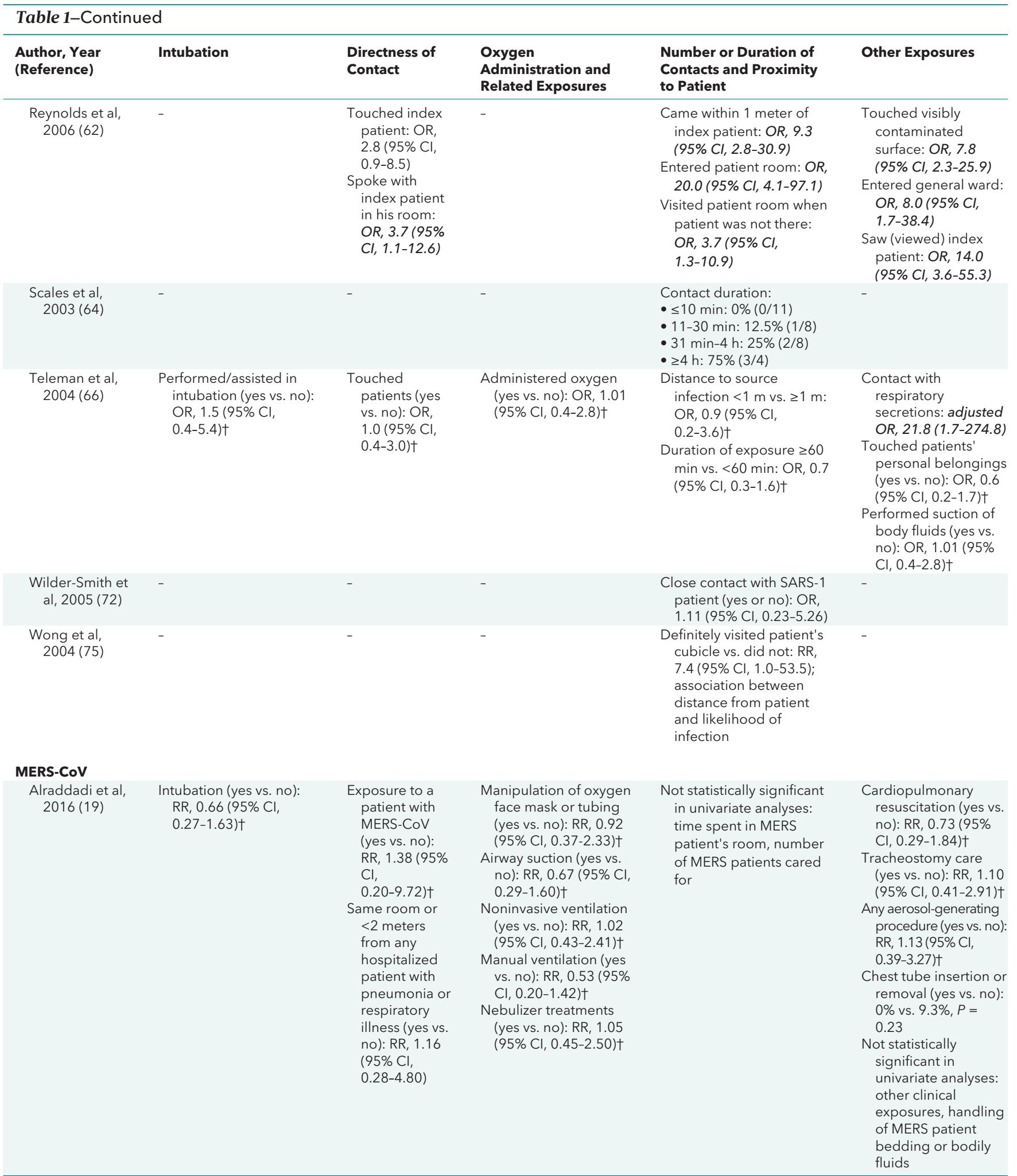

$\mathrm{CoV}=$ coronavirus; $\mathrm{CPR}=$ cardiopulmonary resuscitation; $\mathrm{ECG}=$ electrocardiography; $\mathrm{HCW}=$ health care worker; OR = odds ratio; $\mathrm{RR}=$ relative risk; MERS = Middle East respiratory syndrome; SARS = severe acute respiratory syndrome.

* Values in boldface and italics indicate a statistically significant difference between groups.

† Variable not included in a multivariate model. 
hol dispensers for hand sanitation to be associated with decreased likelihood of HCW SARS-1 infections (adjusted $\mathrm{OR}, 0.05[\mathrm{Cl}, 0.004$ to 0.692$]$ and $0.043[\mathrm{Cl}$, 0.003 to 0.63], respectively) (Appendix Table 7) (76). One study found a higher risk for infections in the emergency department compared with hospital wards (69), and 1 study reported HCW infections in multiple hospital departments (27). Natural air ventilation was associated with decreased risk for SARS-CoV-1 infection versus artificial ventilation in 1 study (adjusted OR, 0.40 [Cl, 0.18 to 0.88$]$ ) (26); another study found a wellventilated office to be associated with a non-statistically significant decreased risk (adjusted OR, $0.32[\mathrm{Cl}, 0.09$ to 1.15]) (58). One study attempted to assess physical aspects of the hospital ward and risk for SARS-1 infection in $\mathrm{HCWs}$, but only evaluated 4 wards, with many confounding factors (35).

HCW Health. Two studies found no association between presence of comorbid conditions in $\mathrm{HCWs}$ and SARS-CoV-1 infection risk $(60,66)$. One study found having an upper respiratory infection in the past 6 months to be associated with decreased risk for SARSCoV-1 infection (62). Another study found an HCW history of to be diabetes associated with increased univariate risk for infection, but it was not an independent predictor (58).

Infection Prevention and Control Factors. The most consistent and robust evidence on PPE measures was on the association between use of masks and decreased infection risk (Table 2) (26, 41, 49, 50, 52, $56-58,60,65,66,72,78)$. Four studies found N95 respirators to be associated with decreased risk versus surgical masks in unadjusted analyses (23, 49, 50, 60). Evidence was inconsistent on the effectiveness of multiple masks versus a single mask $(26,49)$. Most studies found an association between use of gloves $(49,50,56$, $58,60,65,66,72,78)$, gowns $(41,50,52,56,60,65,66$, $78)$, eye protection $(23,26,41,49,52,58,60,78)$, or shoe covers $(26,78)$ and decreased risk for HCW infections (Table 3 ). In some studies, individual PPE measures were not included in multivariate models, but information on the degree of correlation between PPE measures was lacking. When evaluated as "inconsistent use of more than one type of PPE," 1 study found a strong, independent association with increased risk for $\mathrm{HCW}$ infection (adjusted OR 5.06, 95\% Cl 5.06 to 598.92) (41). Studies also found full PPE use (gloves, mask, gown, and eye protection) to be associated with reduced infection risk versus partial PPE (33, 56, 65, 78); some studies found a dose-response relationship between more frequent or consistent PPE use and decreased risk $(26,33,41,78)$. Handwashing was associated with decreased risk for SARS-CoV-1 infection in most studies $(41,52,56,57,65,66,72)$, but there was no association in others $(26,56)$, and handwashing was not included in some multivariate models $(26,52)$. Nasal washing was not independently associated with decreased risk for infection in HCWs in 3 studies $(26,49$, 52). No study evaluated the association between reuse of PPE and infection risk. One study found perceived inadequacy of PPE supplies associated with increased risk for HCW infections (41). Infection control training and education were consistently associated with decreased infection risk, though this finding was not always retained in multivariate models (Table 3$)(26,41$, $49,57,58)$.

\section{MERS-CoV}

One retrospective cohort study of $283 \mathrm{HCWs}$ at a Saudi Arabian hospital found participation in MERSCoV training to be associated with decreased risk for MERS-CoV seropositivity (adjusted RR, $0.33[\mathrm{Cl} 0.12$ to 0.90]) (Appendix Table 7) (19). Cases occurred almost exclusively among HCWs with close contact with patients with MERS. Always using an N95 respirator was associated with a non-statistically significant decreased risk compared with some or no use (adjusted RR, 0.44 $[\mathrm{Cl}, 0.15$ to 1.24$]$ ). Past or current smoking was associated with a nonstatistically increased risk for infection.

Another study evaluated risk factors for MERS-CoV seropositivity in $737 \mathrm{HCWs}$ who had direct contact with a patient with MERS in 31 hospitals in South Korea (37), but only reported 2 cases in HCWs (both of whom had not used appropriate PPE).

\section{Key Question 3: Risk Factors for Transmission of Coronavirus Infection From HCWs}

No study evaluated risk factors for transmission of coronavirus infections from $\mathrm{HCW}$ s to household or other close contacts. Four studies $(24,31,42,73)$ that did not evaluate risk factors for HCW transmission but compared SARS-CoV-1 transmission incidence from HCWs versus non-HCWs to household contacts are described in the full report (10).

\section{DiscUSSION}

This rapid, living review summarizes the evidence on the burden of and risk factors for HCW coronavirus infections. Health care workers account for a significant proportion of infections in these outbreaks. Exposed HCWs may experience a high incidence of infections, particularly for unprotected and repeated exposures, though they appear to experience less severe illness and mortality than non-HCWs, possibly related to younger age and fewer comorbid conditions. Evidence that depression, anxiety, and psychological distress are common in HCWs in the COVID-19 outbreak is consistent with findings from the SARS-1 outbreak (83-90). Evidence on risk factors for coronavirus infections in HCWs is primarily available for SARS-CoV-1, with the strongest evidence indicating an association between PPE use versus nonuse and decreased risk. The association was most consistent for masks but was also observed for gloves, gowns, and eye protection, as well as handwashing. There was evidence that more consistent and full use of recommended PPE measures was associated with decreased risk for infection, suggesting a dose-response relationship, and evidence that N95 respirators might be associated with decreased risk for infection versus surgical masks. Evidence also indicated an association between certain exposures (such as involvement in intubations, direct contact with infected 


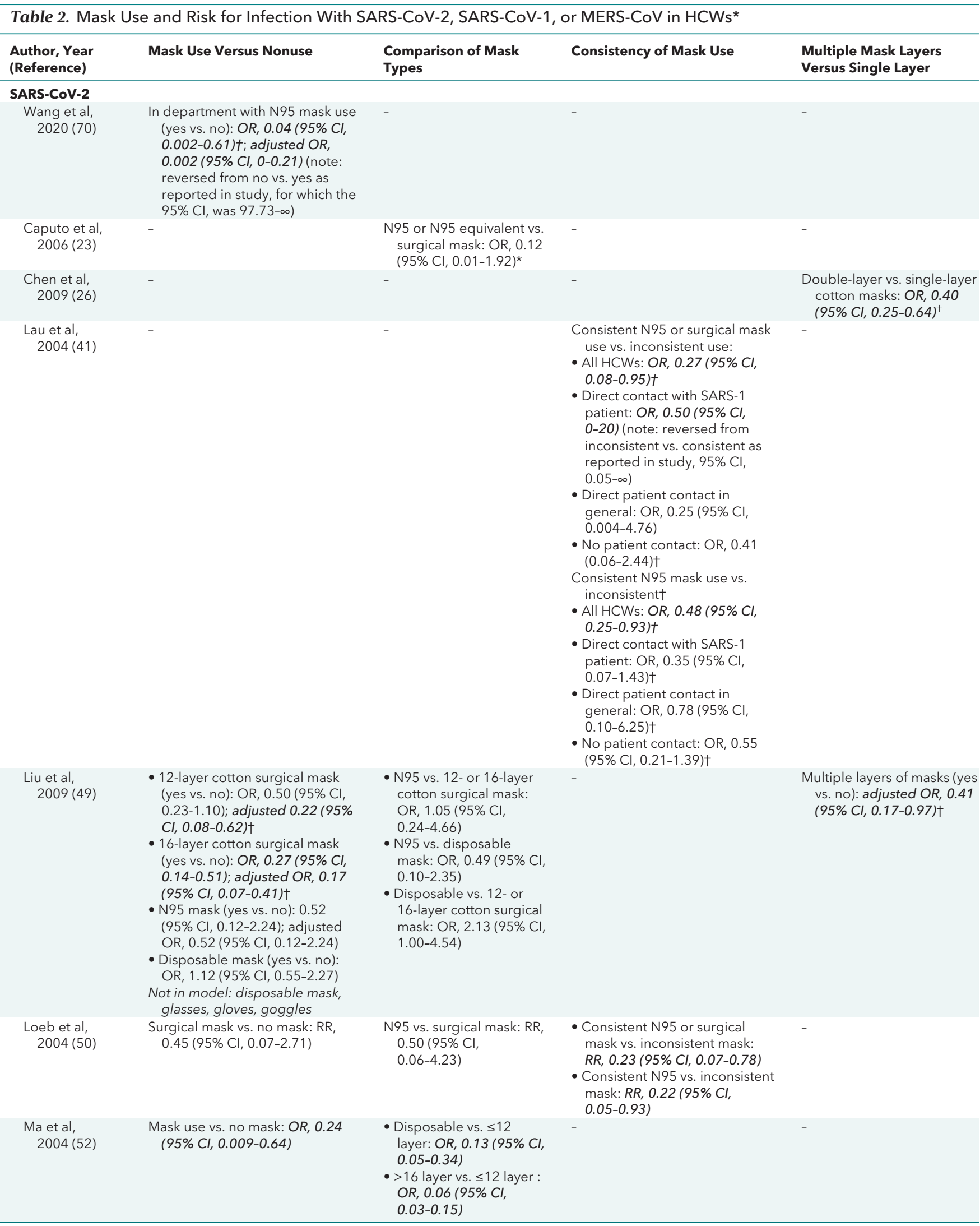




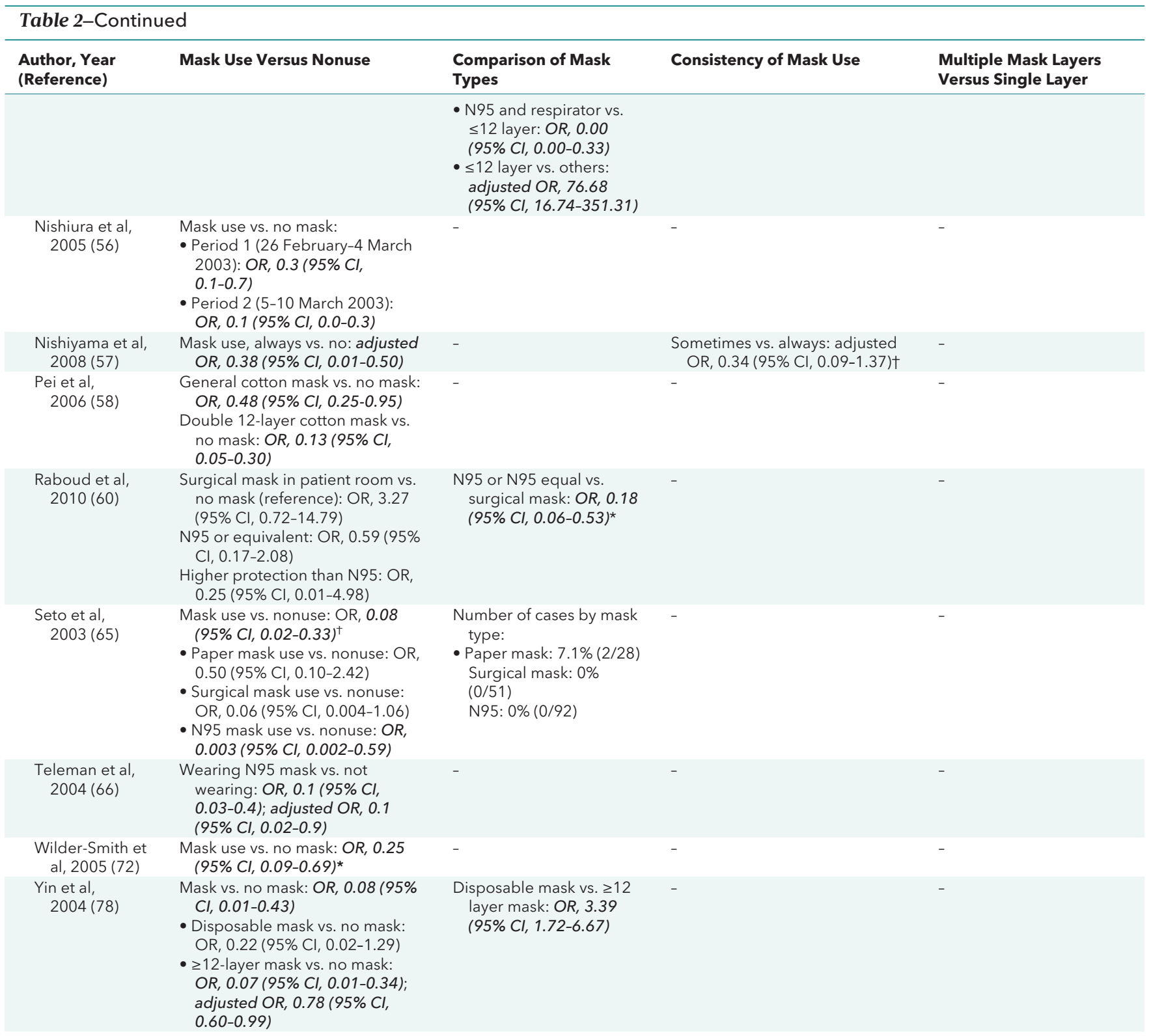

\section{MERS-CoV}

Alradaddi et al, 2016 (19)

Medical mask or N95 respirator, direct contact (use always vs. sometimes/never): RR, 0.69 (95\% Cl, 0.28-1.69)

- Medical mask: RR, 2.06 (95\% Cl, 0.86-4.95)

- N95: RR, $0.44(95 \% \mathrm{Cl}$, $0.17-1.12)$ 


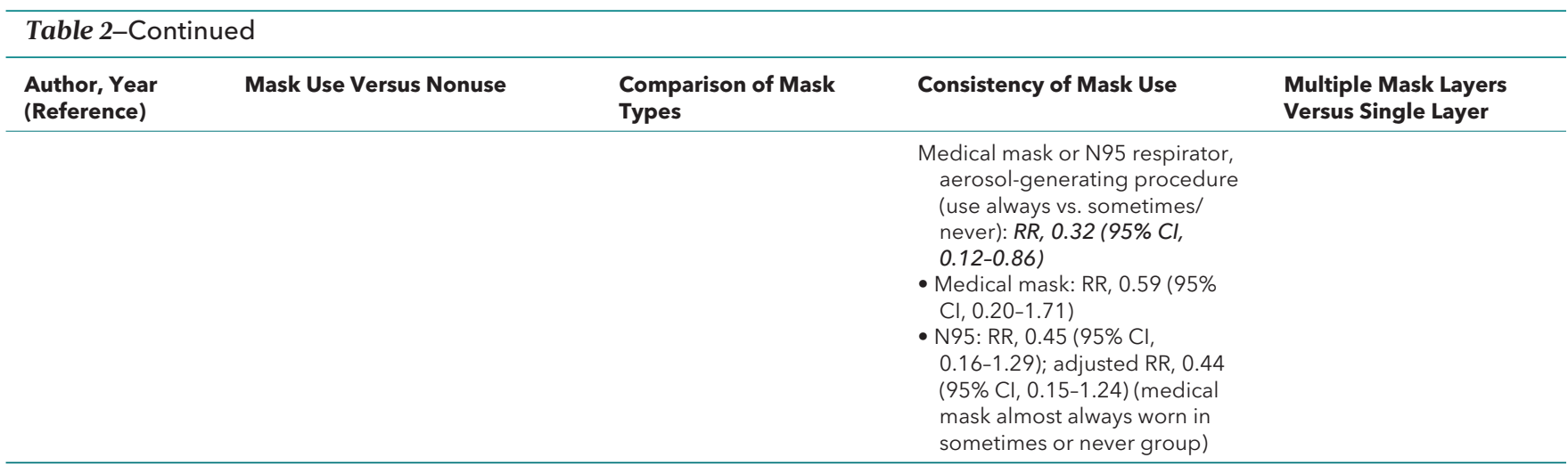

$\mathrm{CoV}=$ coronavirus; $\mathrm{HCW}=$ health care worker; $\mathrm{OR}=$ odds ratio; $\mathrm{RR}=$ relative risk; $\mathrm{MERS}=$ Middle East respiratory syndrome; $\mathrm{SARS}=$ severe acute respiratory syndrome.

* Values in boldface and italics indicate a statistically significant difference between groups.

† Comparison was reversed.

patients, or contact with bodily secretions) and increased infection risk. Education and training in infection control measures were consistently associated with decreased risk for HCW infections.

Our findings are generally consistent with prior reviews on risk factors for respiratory infections in $\mathrm{HCWs}$, including PPE use (91-96). It differs from prior reviews by including recent evidence on risk factors (including those related to SARS-CoV-2 infections), focusing on coronavirus infections, excluding surrogate markers for transmission risk, evaluating a broader array of potential risk factors, and including a more comprehensive set of relevant studies. In addition, we implemented living review processes to incorporate new evidence on an ongoing basis.

The evidence base has important limitations. The evidence on SARS-CoV-2 infections in HCWs is sparse and has methodological limitations. Many studies on the burden of SARS-CoV-2 infections are case series and epidemiologic evaluations; evaluations of clinical cohorts of exposed HCWs are lacking. Studies on SARS-CoV-2 infections in HCWs that reported mental health or sleep outcomes used a cross-sectional design, did not control for baseline status, and did not include a non-HCW comparison group. Almost all studies on risk factors were retrospective and susceptible to recall bias with regard to PPE use and other factors. Some risk factor studies did not control for confounders, and those that did had limited ability to control for exposure intensity and frequency. Few studies that analyzed risk factors in multivariate models addressed collinearity (97), complicating interpretation for potentially correlated risk factors (for example, use of different types of PPE). Case-control studies did not match cases and controls on such factors as age, sex, or HCW role. Applicability of evidence on SARS-CoV-1 and MERSCoV infections to SARS-CoV-2 is uncertain, owing to decreased transmission propensity, greater illness severity, or variability in affected populations. Most evidence on SARS-CoV-2 in HCWs is from China; studies from other settings, including those with de- creased availability or use of infection prevention and control measures, are needed.

The review process had limitations, in particular the use of streamlined rapid review methods for searching and selecting studies. We did not assess study quality by using a formal instrument, though key methodological limitations were highlighted. We included nonpeer-reviewed studies on SARS-CoV-2 infection in $\mathrm{HCWs}$, given the lack of peer-reviewed literature, which may reduce data quality. Meta-analysis was not attempted owing to study limitations and heterogeneity in study designs, comparisons, and analyses.

Studies are needed to better understand the proportion of exposed HCWs who are infected with SARS-CoV-2 and associated outcomes, including economic effects; ability to work; social effects (for example, need for child care); and effects on family members and other close contacts, including transmission. Studies evaluating mental health and other outcomes should control for baseline status, include non-HCW controls, and incorporate longitudinal follow-up. Recovered HCWs require evaluation to understand outcomes over time (such as after return to work). For assessing SARS-CoV-2 infection risk factors, studies that prospectively measure exposures, PPE use, and other factors would increase measurement accuracy, reduce recall bias, and enable analyses that minimize confounding. Multivariate analyses of risk factors should account for potential collinearity. Given current limitations related to PPE supply, research on effects of PPE reuse is a priority (98). Studies are needed on the association between administrative factors, environmental factors, and $\mathrm{HCW}$ health and risk for HCW infections.

In conclusion, HCWs experience significant burdens from coronavirus infections, including SARSCoV-2. Use of PPE and infection control training are associated with decreased infection risk and certain exposures are associated with increased risk. Research is urgently needed on optimal methods for reducing HCW risk for SARS-CoV-2 infections. 


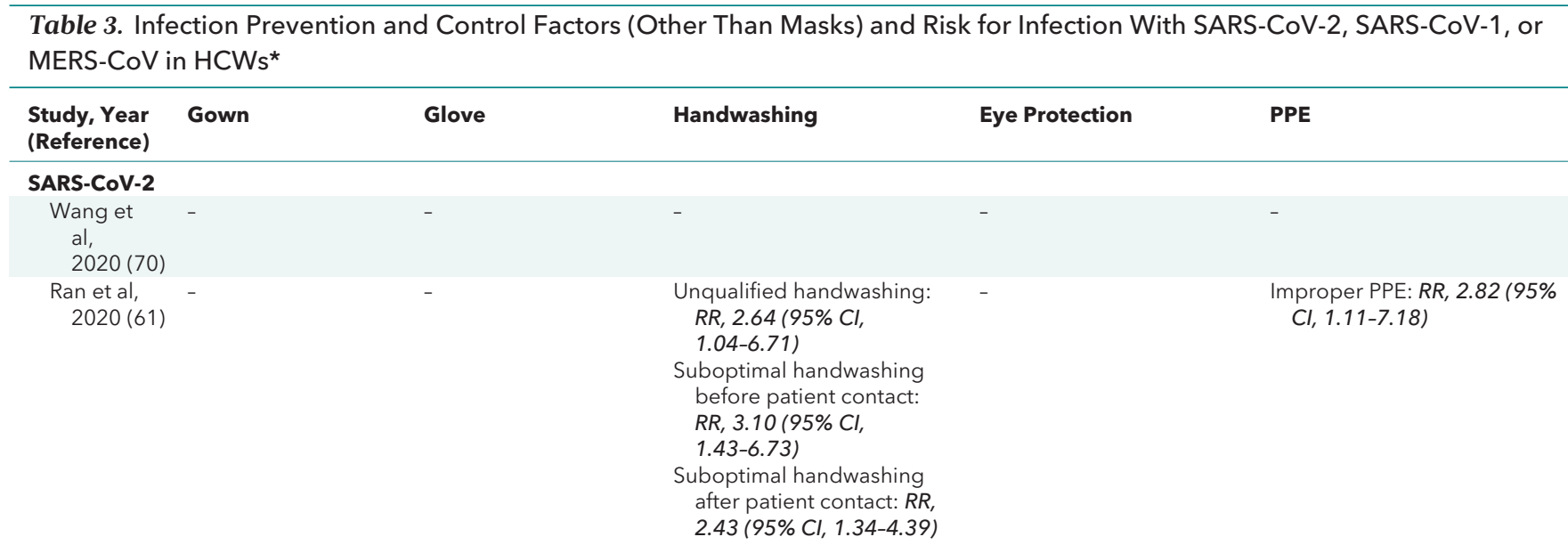

\section{SARS-CoV-1}

\begin{tabular}{|c|c|c|}
\hline $\begin{array}{l}\text { Caputo et } \\
\text { al, } \\
2006(23)\end{array}$ & - & $\begin{array}{l}\text { Double vs. single } \\
\text { layer gloves: OR, } \\
0.04(95 \% \mathrm{Cl} \text {, } \\
0.002-0.78)\end{array}$ \\
\hline $\begin{array}{l}\text { Chen et al, } \\
2009 \text { (26) }\end{array}$ & $\begin{array}{l}\text { Single vs. double } \\
\text { gowns: OR, } 2.12 \\
(95 \% \mathrm{Cl} \\
1.36-3.31)+\end{array}$ & $\begin{array}{l}\text { Single vs. double } \\
\text { gloves: adjusted } \\
\text { OR, } 4.13(95 \% \mathrm{Cl} \text {, } \\
1.99-8.55)\end{array}$ \\
\hline
\end{tabular}

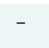

Face shield vs. no face shield: OR, $0.79(95 \%$ $\mathrm{Cl}, 0.07-9.50$ )

Wash hands after caring for SARS-1 patients:

- Never vs. every time: OR, 0.89 (95\% Cl, 0.52-1.51)†

- Sometimes vs. every time: OR, $1.03(95 \% \mathrm{Cl}$, 0.38-2.75)†

- Often vs. every time: OR, 1.14 (95\% Cl, 0.64-2.06)†
Face shield in SARS ward:

- Never vs. every time: OR, 4.05 (95\% Cl, 0.54-30.34)†

- Sometimes vs. every time: OR, $0.22(95 \% \mathrm{Cl}$ 0.01-3.56)†

Goggles while performing operation for SARS-1 patient:

- Never vs. every time: OR, $7.83(95 \% \mathrm{Cl}$ 1.07-57.63)†

- Sometimes vs. every time: OR, $0.84(95 \% \mathrm{Cl}$ 0.07-9.45)†
Powered air purifying respirator or Stryker suit vs. no personal protective system: OR, $0.02(95 \% \mathrm{Cl}$, 0.01-4.12)

Shoe cover use:

- Never vs. every time: OR, 3.80 (95\% Cl, 2.24-6.45)t

- Sometimes vs. every time: OR, 5.04 (2.04-12.48)t

- Often vs. every time: OR, 2.29 (95\% Cl, 0.96-5.67)†

Cap worn:

- Never vs. every time: OR, $1.79(95 \% \mathrm{Cl}, 1.03-3.10) \dagger$

- Sometimes vs. every time: OR 0.48 (0.14-1.67)†

- Often vs. every time: OR, 0.59 (95\% Cl, 0.13-2.65)† Wash uncovered skin after caring for SARS-1 patients:

- Never vs. every time: OR, 3.29 (95\% Cl, 1.29-8.43)t

- Sometimes vs. every time: OR, $2.16(95 \% \mathrm{Cl}$, 0.77-6.05)†

- Often vs. every time: OR, $1.47(0.45-4.79) \dagger$

Wash nasal cavity after caring for SARS-1 patients:

- Never vs. every time: OR 3.21 (95\% Cl, 0.98-10.53)†

- Sometimes vs. every time: OR, $2.51(95 \% \mathrm{Cl}$, 0.72-8.77)†

- Often vs. every time: OR 0.82 (95\% Cl, 0.13-5.13)†

Wash oral cavity after caring for SARS-1 patients:

- Never vs. every time: OR, 3.26 (95\% Cl, 1.15-9.21)†

- Sometimes vs. every time: OR, 2.05 (95\% Cl, 0.67-6.33)†

- Often vs. every time: OR 0.28 (95\% Cl, 0.03-2.59)†

Use of full PPE $100 \%$ of the time vs. $<100 \%$ : RR, 0.19 (95\% Cl, 0.02-1.49)

Protected direct contact vs. unprotected direct contact: RR, $0.16(95 \% \mathrm{Cl}, 0.03-1.02)$

Continued on following page 


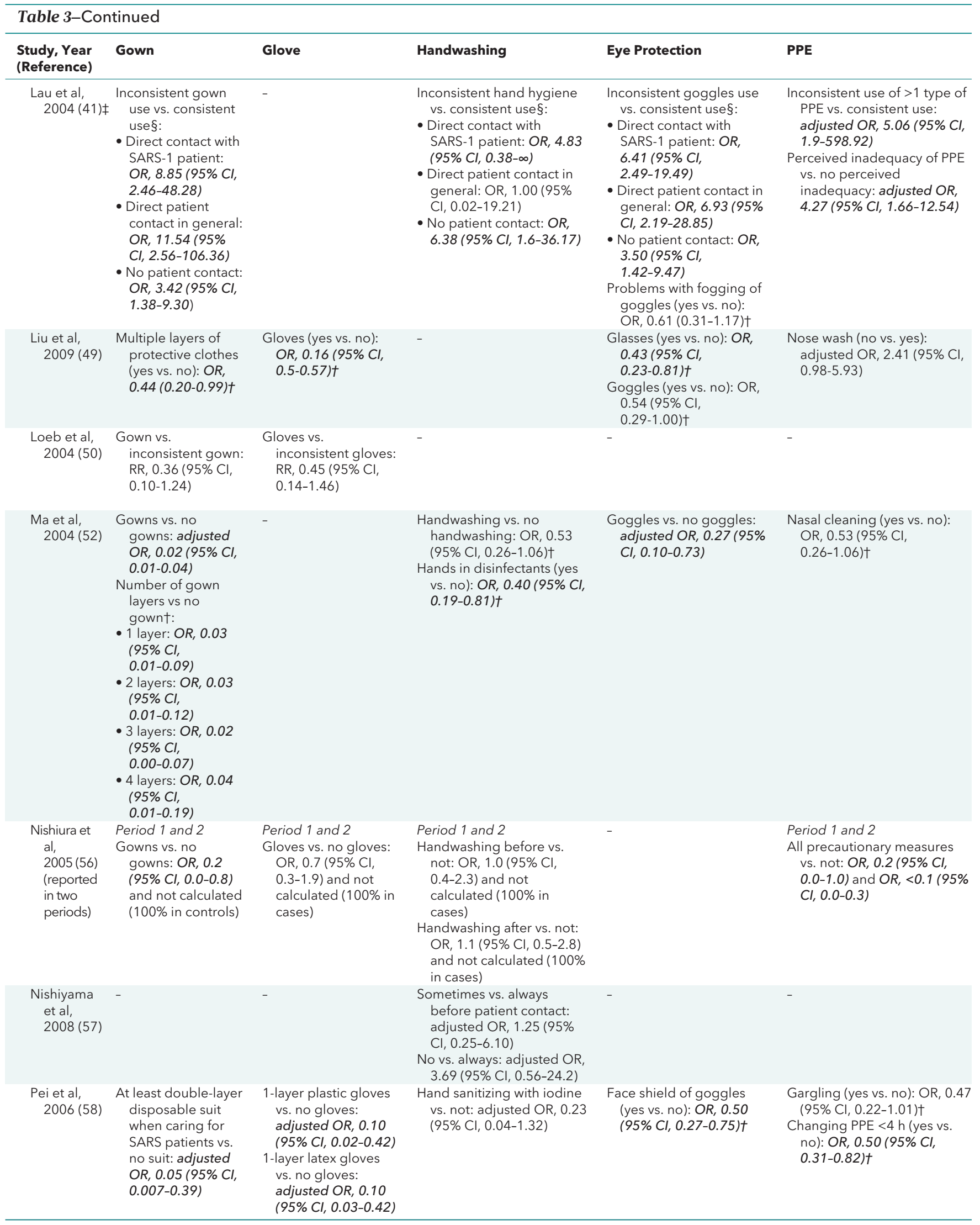




\begin{tabular}{|c|c|c|c|c|c|}
\hline \multicolumn{6}{|c|}{ Table 3-Continued } \\
\hline $\begin{array}{l}\text { Study, Year } \\
\text { (Reference) }\end{array}$ & Gown & Glove & Handwashing & Eye Protection & PPE \\
\hline $\begin{array}{l}\text { Wilder- } \\
\text { Smith et } \\
\text { al, } \\
2005 \text { (72) }\end{array}$ & - & $\begin{array}{l}\text { Glove use vs. no } \\
\text { glove use: OR, } 0.40 \\
(95 \% \mathrm{Cl}, 0.17-0.96)\end{array}$ & $\begin{array}{l}\text { Handwashing vs. no } \\
\text { handwashing: OR } 0.35 \\
\text { (95\% Cl, 0.11-1.12) }\end{array}$ & - & 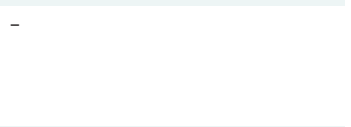 \\
\hline $\begin{array}{l}\text { Yin et al, } \\
2004 \text { (78) }\end{array}$ & $\begin{array}{l}\text { Gown vs. no gown: } \\
\text { OR, 0.22 (95\% Cl, } \\
0.12-0.39) \dagger\end{array}$ & $\begin{array}{l}\text { Gloves vs. no gloves: } \\
\text { OR, 0.30 (95\% Cl, } \\
0.17-0.53)+\end{array}$ & $\begin{array}{l}\text { Disinfect and wash hands } \\
\text { (yes vs. no): OR, 0.49 } \\
(95 \% \text { Cl, 0.2-0.85)† }\end{array}$ & $\begin{array}{l}\text { Use of goggles vs. no use: } \\
\text { adjusted OR, } 0.20(95 \% \\
C l, 0.10-0.41)\end{array}$ & $\begin{array}{l}\text { Mouth washing vs. no mouth } \\
\text { washing: OR, } 0.35 \text { ( } 95 \% \mathrm{Cl} \text {, } \\
0.13-0.93) \dagger \\
\text { Shower and change after } \\
\text { work (before going home) } \\
\text { vs. not: OR, 0.37 ( } 95 \% \mathrm{Cl} \text {, } \\
\text { 0.19-0.72)† } \\
\text { Nose clip vs. no nose clip: OR, } \\
0.70 \text { ( } 95 \% \mathrm{Cl}, 0.38-1.31) \dagger \\
\text { Protection of nasal and eye } \\
\text { mucosa: OR, } 0.13 \text { ( } 95 \% \mathrm{Cl} \text {, } \\
0.02-0.97) \dagger \\
\text { Shoe cover vs. no shoe cover: } \\
\text { adjusted OR, } 0.58(95 \% \mathrm{Cl} \text {, } \\
\text { 0.39-0.86) }\end{array}$ \\
\hline $\begin{array}{l}\text { Kim et al, } \\
2016 \text { (37) }\end{array}$ & - & - & - & - & $\begin{array}{l}\text { Exposure without appropriate } \\
\text { PPE vs. never: } 0.7 \%(2 / 294) \\
\text { vs. } 0 \%(0 / 443) ; P=0.16\end{array}$ \\
\hline
\end{tabular}

$\mathrm{CoV}=$ coronavirus $; \mathrm{HCW}=$ health care worker; $\mathrm{OR}=$ odds ratio; $\mathrm{RR}=$ relative risk; $\mathrm{MERS}=$ Middle East respiratory syndrome; $\mathrm{SARS}=$ severe acute respiratory syndrome.

* Values in boldface and italics indicate a statistically significant difference between groups.

† Variable not included in a multivariate model.

¥ Study reports ORs as matched ORs, except where indicated.

$\S$ Addressed in model as inconsistent use of $>1$ type of PPE item.

From Pacific Northwest Evidence-based Practice Center and Oregon Health \& Science University, Portland, Oregon (R.C., T.D., S.S., A.M.T.); and Pacific Northwest Evidence-based Practice Center and School of Public Health, Oregon Health \& Science University-Portland State University, Portland, Oregon (D.I.B., R.F.).

Disclaimer: This article is the work of the authors and does not represent the views or position of the World Health Organization.
Acknowledgment: The authors thanks Susan L. Norris, MD, $\mathrm{MPH}$, for her role in the development of the Key Questions and scope of this rapid review.

Funding: By the World Health Organization.

Disclosures: Drs. Chou, Buckley, Selph, and Totten and Ms. Dana report grants from the World Health Organization dur- 
ing the conduct of the study. Dr. Fu reports grants received by OHSU during the conduct of the study. Disclosures can also be viewed at www.acponline.org/authors/icmje/ConflictOflnterest Forms.do?msNum=M20-1632.

Corresponding Author: Roger Chou, MD, Oregon Health \& Science University, 3181 SW Sam Jackson Park Road, Mail Code BICC, Portland, OR 97239; e-mail, chour@ohsu.edu.

Current author addresses and author contributions are available at Annals.org.

\section{References}

1. World Health Organization. Novel coronavirus-China 2020. Accessed at www.who.int/csr/don/12-january-2020-novel-coronavirus -china/en/ on 30 March 2020.

2. Lu R, Zhao X, Li J, et al. Genomic characterisation and epidemiology of 2019 novel coronavirus: implications for virus origins and receptor binding. Lancet. 2020;395:565-4. [PMID: 32007145] doi:10 .1016/S0140-6736(20)30251-8

3. Zhou P, Yang XL, Wang XG, et al. A pneumonia outbreak associated with a new coronavirus of probable bat origin. Nature. 2020; 579:270-273. [PMID: 32015507] doi:10.1038/s41586-020-2012-7 4. Zhu N, Zhang D, Wang W, et al; China Novel Coronavirus Investigating and Research Team. A novel coronavirus from patients with pneumonia in China, 2019. N Engl J Med. 2020;382:727-3. [PMID: 31978945] doi:10.1056/NEJMoa2001017

5. World Health Organization. Novel coronavirus (2019-nCov)-Situation Report 22 2020. Accessed at www.who.int/docs/default-source /coronaviruse/situation-reports/20200211-sitrep-22-ncov.pdf?sfvrsn= fb6d49b1_2 on 30 March 2020.

6. Koh D. Occupational risks for COVID-19 infection [Editorial]. Occup Med (Lond). 2020;70:3-5. [PMID: 32107548] doi:10.1093 loccmed/kqaa036

7. Wang D, Hu B, Hu C, et al. Clinical characteristics of 138 hospitalized patients with 2019 novel coronavirus-infected pneumonia in Wuhan, China. JAMA. 2020. [PMID: 32031570] doi:10.1001/jama .2020 .1585

8. Adams JG, Walls RM. Supporting the health care workforce during the COVID-19 global epidemic. JAMA. 2020. [PMID: 32163102] doi:10.1001/jama.2020.3972

9. Perlis RH. Exercising heart and head in managing coronavirus disease 2019 in Wuhan. JAMA Netw Open. 2020;3:e204006. [PMID: 32202641] doi:10.1001/jamanetworkopen.2020.4006

10. Chou R, Dana T, Buckley D, et al. Healthcare workers and coronaviruses: epidemiology and risk factors for infection rapid review. World Health Organization. 2020. [Forthcoming].

11. Haby MM, Chapman E, Clark R, et al. What are the best methodologies for rapid reviews of the research evidence for evidenceinformed decision making in health policy and practice: a rapid review. Health Res Policy Syst. 2016;14:83. [PMID: 27884208]

12. Elliott JH, Synnot A, Turner T, et al; Living Systematic Review Network. Living systematic review: 1. Introduction-the why, what, when, and how. J Clin Epidemiol. 2017;91:23-30. [PMID: 28912002] doi:10.1016/j.jclinepi.2017.08.010

13. World Health Organization. Database of publications on coronavirus disease (COVID-19) 2020. Accessed at www.who .int/emergencies/diseases/novel-coronavirus-2019/global-researchon-novel-coronavirus-2019-ncov on 30 March 2020.

14. Cold Spring Harbor Laboratory. medRxiv: the preprint server of health sciences. Accessed at www.medrxiv.org/ on 30 March 2020. 15. University of Bristol Centre for Research Synthesis and Decision Analysis. The ROBINS-E tool (Risk Of Bias In Non-randomized Studies of Exposures). Accessed at www.bristol.ac.uk/population-health -sciences/centres/cresyda/barr/riskofbias/robins-e on 30 March 2020.
16. Wells GA, Shea B, O'Connell D, et al. The Newcastle-Ottawa Scale (NOS) for assessing the quality of nonrandomised studies in meta-analyses. Accessed at www.ohri.ca/programs/clinical_epidemiology/oxford.asp on 30 March 2020.

17. Adegboye O, Saffary T, Adegboye M, et al. Individual and network characteristic associated with hospital-acquired Middle East Respiratory Syndrome coronavirus. J Infect Public Health. 2019 May Jun;12:343-349. [PMID: 30578142] doi:10.1016/j.jiph.2018.12.002

18. Al-Abdallat MM, Payne DC, Alqasrawi S, et al; Jordan MERS-CoV Investigation Team. Hospital-associated outbreak of Middle East respiratory syndrome coronavirus: a serologic, epidemiologic, and clinical description. Clin Infect Dis. 2014;59:1225-33. [PMID: 24829216] doi:10.1093/cid/ciu359

19. Alraddadi BM, Al-Salmi HS, Jacobs-Slifka K, et al. Risk factors for Middle East respiratory syndrome coronavirus infection among healthcare personnel. Emerg Infect Dis. 2016;22:1915-1920. [PMID: 27767011] doi:10.3201/eid2211.160920

20. Al-Tawfiq JA, Memish ZA. Middle East respiratory syndrome coronavirus in the last two years: health care workers still at risk. Am J Infect Control. 2019;47:1167-1170. [PMID: 31128983] doi:10.1016/j .ajic.2019.04.007

21. Amer $\mathrm{H}$, Alqahtani AS, Alaklobi F, et al. Healthcare worker exposure to Middle East respiratory syndrome coronavirus (MERS-CoV): revision of screening strategies urgently needed. Int J Infect Dis. 2018;71:113-116. [PMID: 29649550] doi:10.1016/j.ijid.2018.04.001 22. Bernard-Stoecklin S, Nikolay B, Assiri A, et al. Comparative analysis of eleven healthcare-associated outbreaks of Middle East respiratory syndrome coronavirus (Mers-cov) from 2015 to 2017. Sci Rep. 2019;9:7385. [PMID: 31089148] doi:10.1038/s41598-019-43586-9

23. Caputo KM, Byrick R, Chapman MG, et al. Intubation of SARS patients: infection and perspectives of healthcare workers. Can J Anaesth. 2006;53:122-19. [PMID: 16434750]

24. Chan LY, Wong JT, Li PK, et al. Risk of transmission of severe acute respiratory syndrome to household contacts by infected health care workers and patients. Am J Med. 2004;116:559-60. [PMID: 15063819]

25. Chang WT, Kao CL, Chung MY, et al. SARS exposure and emergency department workers. Emerg Infect Dis. 2004;10:1117-9. [PMID: 15207066]

26. Chen WQ, Ling $\mathrm{WH}$, Lu CY, et al. Which preventive measures might protect health care workers from SARS? BMC Public Health. 2009;9:81. [PMID: 19284644] doi:10.1186/1471-2458-9-81

27. Chen WQ, Lu CY, Wong TW, et al. Anti-SARS-CoV immunoglobulin $G$ in healthcare workers, Guangzhou, China. Emerg Infect Dis. 2005;11:89-94. [PMID: 15705328]

28. Dai $Y, H u ~ G$, Xiong $H$, et al. Psychological impact of the coronavirus disease 2019 (COVID-19) outbreak on healthcare workers in China. medRxiv. 2020:2020.03.03.20030874. doi: 10.1101/2020.03 .03.20030874.

29. Elkholy AA, Grant R, Assiri A, et al. MERS-CoV infection among healthcare workers and risk factors for death: retrospective analysis of all laboratory-confirmed cases reported to WHO from 2012 to 2 June 2018. J Infect Public Health. 2020;13:418-422. [PMID: 31056437] doi:10.1016/j.jiph.2019.04.011

30. Fowler RA, Guest CB, Lapinsky SE, et al. Transmission of severe acute respiratory syndrome during intubation and mechanical ventilation. Am J Respir Crit Care Med. 2004;169:1198-202. [PMID: 14990393]

31. Goh DL, Lee BW, Chia KS, et al. Secondary household transmission of SARS, Singapore. Emerg Infect Dis. 2004;10:232-4. [PMID: 15030688]

32. Ho AS, Sung JJ, Chan-Yeung M. An outbreak of severe acute respiratory syndrome among hospital workers in a community hospital in Hong Kong. Ann Intern Med. 2003;139:564-7. [PMID: 14530227]

33. Ho KY, Singh KS, Habib AG, et al. Mild illness associated with severe acute respiratory syndrome coronavirus infection: lessons from a prospective seroepidemiologic study of health-care workers in a teaching hospital in Singapore. J Infect Dis. 2004;189:642-7. [PMID: 14767817] 
34. Ip M, Chan PK, Lee N, et al. Seroprevalence of antibody to severe acute respiratory syndrome (SARS)-associated coronavirus among health care workers in SARS and non-SARS medical wards. Clin Infect Dis. 2004;38:e116-8. [PMID: 15227633]

35. Jiang $S$, Huang L, Chen $X$, et al. Ventilation of wards and nosocomial outbreak of severe acute respiratory syndrome among healthcare workers. Chin Med J (Engl). 2003;116:1293-7. [PMID: 14527351]

36. Kang L, Ma S, Chen M, et al. Impact on mental health and perceptions of psychological care among medical and nursing staff in Wuhan during the 2019 novel coronavirus disease outbreak: a crosssectional study. Brain Behav Immun. 2020. [PMID: 32240764] doi:10 .1016/j.bbi.2020.03.028

37. Kim CJ, Choi WS, Jung Y, et al. Surveillance of the Middle East respiratory syndrome (MERS) coronavirus (CoV) infection in healthcare workers after contact with confirmed MERS patients: incidence and risk factors of MERS-CoV seropositivity. Clin Microbiol Infect. 2016;22:880-886. [PMID: 27475739] doi:10.1016/j.cmi.2016.07.017 38. Kim T, Jung J, Kim SM, et al. Transmission among healthcare worker contacts with a Middle East respiratory syndrome patient in a single Korean centre [Letter]. Clin Microbiol Infect. 2016;22:e11-e13. [PMID: 26384679] doi:10.1016/j.cmi.2015.09.007

39. Kluytmans $M$, Buiting $A$, Pas $S$, et al. SARS-CoV-2 infection in 86 healthcare workers in two Dutch hospitals in March 2020. medRxiv. 2020:2020.03.23.20041913. doi: 10.1101/2020.03.23.20041913

40. Lai J, Ma S, Wang Y, et al. Factors associated with mental health outcomes among health care workers exposed to coronavirus disease 2019. JAMA Netw Open. 2020;3:e203976. [PMID: 32202646] doi:10.1001/jamanetworkopen.2020.3976

41. Lau JT, Fung KS, Wong TW, et al. SARS transmission among hospital workers in Hong Kong. Emerg Infect Dis. 2004;10:280-6. [PMID: 15030698]

42. Lau JT, Lau M, Kim JH, et al. Probable secondary infections in households of SARS patients in Hong Kong. Emerg Infect Dis. 2004; 10:235-43. [PMID: 15030689]

43. Lau JT, Yang $X$, Leung PC, et al. SARS in three categories of hospital workers, Hong Kong. Emerg Infect Dis. 2004;10:1399-404. [PMID: 15496240]

44. Leung GM, Hedley AJ, Ho LM, et al. The epidemiology of severe acute respiratory syndrome in the 2003 Hong Kong epidemic: an analysis of all 1755 patients. Ann Intern Med. 2004;141:662-73. [PMID: 15520422]

45. Li L, Cheng S, Gu J. SARS infection among health care workers in Beijing, China [Letter]. JAMA. 2003;290:2662-3. [PMID: 14645305] 46. Liu C, Yang YZ, Zhang XM, et al. The prevalence and influencing factors for anxiety in medical workers fighting COVID-19 in China: a cross-sectional survey. medRxiv. 2020:2020.03.05.20032003. doi: 10 $.1101 / 2020.03 .05 .20032003$

47. Liu J, Ouyang L, Guo P, et al. Epidemiological, clinical characteristics and outcome of medical staff infected with COVID-19 in Wuhan, China: a retrospective case series analysis. medRxiv. 2020: 2020.03.09.20033118. doi: 10.1101/2020.03.09.20033118

48. Liu M, He P, Liu HG, et al. [Clinical characteristics of 30 medical workers infected with new coronavirus pneumonia]. Zhonghua Jie $\mathrm{He} \mathrm{He} \mathrm{Hu} \mathrm{Xi} \mathrm{Za} \mathrm{Zhi.} \mathrm{2020;43:209-214.} \mathrm{[PMID:} \mathrm{32164090]} \mathrm{doi:10}$ .3760/cma.j.issn.1001-0939.2020.03.014

49. Liu W, Tang F, Fang LQ, et al. Risk factors for SARS infection among hospital healthcare workers in Beijing: a case control study. Trop Med Int Health. 2009;14(SUPPL. 1):52-9. doi: 10.1111/j.13653156.2009.02255.x

50. Loeb M, McGeer A, Henry B, et al. SARS among critical care nurses, Toronto. Emerg Infect Dis. 2004;10:251-5. [PMID: 15030692] 51. Lu W, Wang $H$, Lin $Y$, et al. Psychological status of medical workforce during the COVID-19 pandemic: a cross-sectional study. Psychiatry Res. 2020;288:112936. [PMID: 32276196] doi:10.1016/j.psychres .2020 .112936

52. Ma HJ, Wang HW, Fang LQ, et al. [A case-control study on the risk factors of severe acute respiratory syndromes among health care workers]. Zhonghua Liu Xing Bing Xue Za Zhi. 2004;25:741-4. [PMID: 15555351]
53. McMichael TM, Currie DW, Clark S, et al. Epidemiology of Covid-19 in a long-term care facility in King County, Washington. N Engl J Med. 2020. [PMID: 32220208] doi:10.1056/NEJMoa2005412 54. Memish ZA, Al-Tawfiq JA, Makhdoom HQ, et al. Screening for Middle East respiratory syndrome coronavirus infection in hospital patients and their healthcare worker and family contacts: a prospective descriptive study. Clin Microbiol Infect. 2014;20:469-74. [PMID: 24460984] doi:10.1111/1469-0691.12562

55. Ng K, Poon BH, Kiat Puar TH, et al. COVID-19 and the risk to health care workers: a case report. Ann Intern Med. 2020. [PMID: 32176257] doi:10.7326/L20-0175

56. Nishiura H, Kuratsuji T, Quy T, et al. Rapid awareness and transmission of severe acute respiratory syndrome in Hano French Hospital, Vietnam. Am J Trop Med Hyg. 2005;73:17-25. [PMID: 16014825]

57. Nishiyama A, Wakasugi N, Kirikae T, et al. Risk factors for SARS infection within hospitals in Hanoi, Vietnam. Jpn J Infect Dis. 2008; 61:388-90. [PMID: 18806349]

58. Pei LY, Gao ZC, Yang Z, et al. Investigation of the influencing factors on severe acute respiratory syndrome among health care workers. Beijing Da Xue Xue Bao Yi Xue Ban. 2006;38:271-5. [PMID: 16778970]

59. Qi J, Xu J, Li B, et al. The evaluation of sleep disturbances for Chinese frontline medical workers under the outbreak of COVID-19. medRxiv. 2020:2020.03.06.20031278. doi: 10.1101/2020.03.06 .20031278

60. Raboud J, Shigayeva A, McGeer A, et al. Risk factors for SARS transmission from patients requiring intubation: a multicentre investigation in Toronto, Canada. PLoS One. 2010;5:e10717. [PMID: 20502660] doi:10.1371/journal.pone.0010717

61. Ran L, Chen X, Wang Y, et al. Risk factors of healthcare workers with corona virus disease 2019: a retrospective cohort study in a designated hospital of Wuhan in China. Clin Infect Dis. 2020. [PMID: 32179890] doi:10.1093/cid/ciaa287

62. Reynolds MG, Anh BH, Thu VH, et al. Factors associated with nosocomial SARS-CoV transmission among healthcare workers in Hanoi, Vietnam, 2003. BMC Public Health. 2006;6:207. [PMID: 16907978]

63. Ryu B, Cho SI, Oh MD, et al. Seroprevalence of Middle East respiratory syndrome coronavirus (MERS-CoV) in public health workers responding to a MERS outbreak in Seoul, Republic of Korea, in 2015. Western Pac Surveill Response J. 2019 Apr-Jun;10:46-48. [PMID: 31720054] doi:10.5365/wpsar.2018.9.3.002

64. Scales DC, Green K, Chan AK, et al. Illness in intensive care staff after brief exposure to severe acute respiratory syndrome. Emerg Infect Dis. 2003;9:1205-10. [PMID: 14609453]

65. Seto WH, Tsang D, Yung RW, et al; Advisors of Expert SARS group of Hospital Authority. Effectiveness of precautions against droplets and contact in prevention of nosocomial transmission of severe acute respiratory syndrome (SARS). Lancet. 2003;361:151920. [PMID: 12737864]

66. Teleman MD, Boudville IC, Heng BH, et al. Factors associated with transmission of severe acute respiratory syndrome among health-care workers in Singapore. Epidemiol Infect. 2004;132:797803. [PMID: 15473141]

67. Novel Coronavirus Pneumonia Emergency Response Epidemiology Team. [The epidemiological characteristics of an outbreak of 2019 novel coronavirus diseases (COVID-19) in China]. Zhonghua Liu Xing Bing Xue Za Zhi. 2020;41:145-151. [PMID: 32064853] doi: 10.3760/cma.j.issn.0254-6450.2020.02.003

68. Wang C, Liu L, Hao X, et al. Evolving epidemiology and impact of non-pharmaceutical interventions on the outbreak of coronavirus disease 2019 in Wuhan, China. medRxiv. 2020:2020.03.03.20030593. doi: 10.1101/2020.03.03.20030593

69. Wang FD, Chen YY, Lee YM, et al. Positive rate of serum SARSCoV immunoglobulin $\mathrm{G}$ antibody among healthcare workers. Scand J Infect Dis. 2007;39:152-6. [PMID: 17366033]

70. Wang X, Pan Z, Cheng Z. Association between 2019-nCoV transmission and N95 respirator use [Letter]. J Hosp Infect. 2020. [PMID: 32142885] doi:10.1016/j.jhin.2020.02.021 
71. Wiboonchutikul S, Manosuthi W, Likanonsakul S, et al. Lack of transmission among healthcare workers in contact with a case of Middle East respiratory syndrome coronavirus infection in Thailand. Antimicrob Resist Infect Control. 2016;5:21. [PMID: 27222710] doi: 10.1186/s13756-016-0120-9

72. Wilder-Smith A, Teleman MD, Heng BH, et al. Asymptomatic SARS coronavirus infection among healthcare workers, Singapore. Emerg Infect Dis. 2005;11:1142-5. [PMID: 16022801]

73. Wilson-Clark SD, Deeks SL, Gournis E, et al. Household transmission of SARS, 2003. CMAJ. 2006;175:1219-23. [PMID: 17098951]

74. Wong SF, Chow KM, Shek CC, et al. Measures to prevent healtcare workers from contracting severe acute respiratory syndrome during high-risk surgical procedures. Eur J Clin Microbiol Infect Dis. 2004;23:131-3. [PMID: 14712366]

75. Wong TW, Lee CK, Tam W, et al; Outbreak Study Group. Cluster of SARS among medical students exposed to single patient, Hong Kong. Emerg Infect Dis. 2004;10:269-76. [PMID: 15030696]

76. Yen MY, Lin YE, Lee $\mathrm{CH}$, et al. Taiwan's traffic control bundle and the elimination of nosocomial severe acute respiratory syndrome among healthcare workers. J Hosp Infect. 2011;77:332-7. [PMID: 21316802] doi:10.1016/j.jhin.2010.12.002

77. Yen MY, Lin YE, Su IJ, et al. Using an integrated infection control strategy during outbreak control to minimize nosocomial infection of severe acute respiratory syndrome among healthcare workers. J Hosp Infect. 2006;62:195-9. [PMID: 16153744]

78. Yin WW, Gao LD, Lin WS, et al. [Effectiveness of personal protective measures in prevention of nosocomial transmission of severe acute respiratory syndrome]. Zhonghua Liu Xing Bing Xue Za Zhi. 2004;25:18-22. [PMID: 15061941]

79. Ying Y, Kong F, Zhu B, et al. Mental health status among family members of health care workers in Ningbo, China during the coronavirus disease 2019 (COVID-19) outbreak: a cross-sectional study. medRxiv. 2020:2020.03.13.20033290. doi: 10.1101/2020.03.13 .20033290

80. Zhu Z, Xu S, Wang H, et al. COVID-19 in Wuhan: immediate psychological impact on 5062 health workers. medRxiv. 2020: 2020.02.20.20025338. doi: 10.1101/2020.02.20.20025338.

81. World Health Organization. Emergency preparedness responsesummary of probable SARS cases with onset of illness from 1 November 2002 to 31 July 2003. Accessed at www.who.int/csr/sars/country/ table2004_04_21/en on 30 March 2020.

82. World Health Organization Regional Office for the Eastern Mediterranean. MERS situation update 2019. Accessed at http://applications .emro.who.int/docs/EMCSR246E.pdf?ua=1 on 30 March 2020.

83. Bai $Y$, Lin CC, Lin CY, et al. Survey of stress reactions among health care workers involved with the SARS outbreak. Psychiatr Serv. 2004;55:1055-7. [PMID: 15345768]

84. McAlonan GM, Lee AM, Cheung V, et al. Immediate and sustained psychological impact of an emerging infectious disease outbreak on health care workers. Can J Psychiatry. 2007;52:241-7. [PMID: 17500305]
85. Chua SE, Cheung V, Cheung C, et al. Psychological effects of the SARS outbreak in Hong Kong on high-risk health care workers. Can J Psychiatry. 2004;49:391-3. [PMID: 15283534]

86. Lin CY, Peng YC, Wu YH, et al. The psychological effect of severe acute respiratory syndrome on emergency department staff. Emerg Med J. 2007;24:12-7. [PMID: 17183035]

87. Maunder RG, Lancee WJ, Balderson KE, et al. Long-term psychological and occupational effects of providing hospital healthcare during SARS outbreak. Emerg Infect Dis. 2006;12:1924-32. [PMID: 17326946]

88. Nickell LA, Crighton EJ, Tracy CS, et al. Psychosocial effects of SARS on hospital staff: survey of a large tertiary care institution. CMAJ. 2004;170:793-8. [PMID: 14993174]

89. Wu P, Fang Y, Guan Z, et al. The psychological impact of the SARS epidemic on hospital employees in China: exposure, risk perception, and altruistic acceptance of risk. Can J Psychiatry. 2009;54: 302-11. [PMID: 19497162]

90. Koh D, Lim MK, Chia SE, et al. Risk perception and impact of Severe Acute Respiratory Syndrome (SARS) on work and personal lives of healthcare workers in Singapore: what can we learn? Med Care. 2005;43:676-82. [PMID: 15970782]

91. Bartoszko JJ, Farooqi MAM, Alhazzani W, et al. Medical masks vs N95 respirators for preventing COVID-19 in healthcare workers: a systematic review and meta-analysis of randomized trials. Influenza Other Respir Viruses. 2020. [PMID: 32246890] doi:10.1111/irv .12745

92. Jefferson T, Foxlee R, Del Mar C, et al. Physical interventions to interrupt or reduce the spread of respiratory viruses: systematic review. BMJ. 2008;336:77-80. [PMID: 18042961]

93. Maclntyre CR, Chughtai AA. Facemasks for the prevention of infection in healthcare and community settings. BMJ. 2015;350: h694. [PMID: 25858901] doi:10.1136/bmj.h694

94. Offeddu V, Yung CF, Low MSF, et al. Effectiveness of masks and respirators against respiratory infections in healthcare workers: a systematic review and meta-analysis. Clin Infect Dis. 2017;65:19341942. [PMID: 29140516] doi:10.1093/cid/cix681

95. Tran K, Cimon K, Severn M, et al. Aerosol generating procedures and risk of transmission of acute respiratory infections to healthcare workers: a systematic review. PLoS One. 2012;7:e35797. [PMID: 22563403] doi:10.1371/journal.pone.0035797

96. Verbeek JH, Rajamaki B, ljaz S, et al. Personal protective equipment for preventing highly infectious diseases due to exposure to contaminated body fluids in healthcare staff. Cochrane Database Syst Rev. 2020;4:CD011621. [PMID: 32293717] doi:10.1002/14651858.CD011621.pub4

97. Mela CF, Kopalle PK. The impact of collinearity on regression analysis: the asymmetric effect of negative and positive correlations. Applied Economics. 2002;34:667-77. doi: 10 1080/00036840110058482

98. Ranney ML, Griffeth V, Jha AK. Critical supply shortages - the need for ventilators and personal protective equipment during the Covid-19 pandemic. N Engl J Med. 2020;382:e41. [PMID: 32212516] doi:10.1056/NEJMp2006141 
Current Author Addresses: Drs. Chou, Buckley, Selph, Fu, and Totten and Ms. Dana: Oregon Health \& Science University, 3181 SW Sam Jackson Park Road, Mail Code BICC, Portland, OR 97239.
Author Contributions: Conception and design; R. Chou, T. Dana, D.I. Buckley.

Analysis and interpretation of the data: R. Chou, T. Dana, D.I. Buckley, R.W. Fu, A.M. Totten.

Drafting of the article: R. Chou, T. Dana, A.M. Totten.

Critical revision for important intellectual content: R. Chou, D.I. Buckley, A.M. Totten.

Final approval of the article: R. Chou, T. Dana, D.I. Buckley, S.S. Selph, R.W. Fu, A.M. Totten.

Statistical expertise: R. Chou, R.W. Fu.

Obtaining of funding: R. Chou.

Administrative, technical, or logistic support: R. Chou, T. Dana.

Collection and assembly of data: R. Chou, T. Dana, D.I. Buckley, S.S. Selph, R.W. Fu, A.M. Totten.

\begin{tabular}{|c|c|}
\hline \multicolumn{2}{|c|}{ Appendix Table 1. Search Strategies } \\
\hline Database & Search Strategy \\
\hline MEDLINE (PubMed) & $\begin{array}{l}\text { ((((((((COVID } 19 \text { OR "sars cov" OR "nCOV" OR "coronavirus 2") OR ("novel coronavirus" AND (2019: 2020[pdat]))) } \\
\text { OR ("Severe Acute Respiratory Syndrome"[Mesh])) OR ("SARS")) OR ("Middle East Respiratory Syndrome } \\
\text { Coronavirus"[Mesh])) OR (MERS)) OR ("severe acute respiratory syndrome coronavirus 2"[Supplementary } \\
\text { Concept])) OR ("COVID-19"[Supplementary Concept])) AND ((("Health Personnel"[Mesh]) OR (clinician OR } \\
\text { clinicians OR doctor OR doctors OR physician OR physician OR nurse OR nurses OR midwife OR midwives OR } \\
\text { ambulance OR "first responder" OR "first responders" OR "EMT" OR "EMTs")) OR ((health OR healthcare OR } \\
\text { "health care" OR clinic* OR medical OR laboratory) AND (work OR worker* OR personnel OR practitioner* OR } \\
\text { staff OR employee*))) }\end{array}$ \\
\hline Embase (Elsevier) & $\begin{array}{l}\text { ('covid 19' OR (covid AND 19) OR `sars cov' OR ncov OR 'coronavirus 2' OR 'novel coronavirus' OR 'middle east } \\
\text { respiratory syndrome coronavirus' OR 'mers' OR 'severe acute respiratory syndrome' OR 'sars') AND ('health } \\
\text { care personnel' OR 'health workforce' OR clinician OR clinicians OR doctor OR doctors OR physician OR } \\
\text { physician OR nurse OR nurses OR midwife OR midwives OR ambulance OR`first responder' OR`first } \\
\text { responders' OR 'EMT' OR 'EMTs') AND [embase]/lim NOT ([embase]/lim AND [medline]/lim) }\end{array}$ \\
\hline
\end{tabular}




\begin{tabular}{|c|c|c|}
\hline \multicolumn{3}{|c|}{ Appendix Table 2. Inclusion Criteria } \\
\hline Study Aspect & Inclusion & Exclusion \\
\hline Population & $\begin{array}{l}\text { KQ 1: HCW at risk for or with SARS-CoV-2, SARS-CoV-1, or MERS-CoV infection } \\
\text { KQ 2: HCW at risk for SARS-CoV-2, SARS-CoV-1, or MERS-CoV infection } \\
\text { KO 3: Household contacts of HCW infected with SARS-CoV-2, SARS-CoV-1, or } \\
\text { MERS-CoV }\end{array}$ & $\begin{array}{l}\text { KO 1, 2: Non-HCW } \\
\text { KO 3: Nonhousehold HCW } \\
\text { contacts }\end{array}$ \\
\hline Exposures/risk factors & $\begin{array}{l}\text { KQ 1: SARS-CoV-2, SARS-CoV-1, or MERS-CoV infection } \\
\text { KQ 2: } \\
\text { Demographic characteristics: age, sex } \\
\text { Exposure history: in workplace, home, or community } \\
\text { Professional role/position } \\
\text { Administrative factors: policies; point of care assessment; patient flow/triage; } \\
\text { use, training, adherence, availability of personal protective equipment; hours } \\
\text { worked, shifts; contact hours } \\
\text { Health care setting and environment: unit worked (high-risk department e.g. } \\
\text { ICU; lower risk, e.g. triage; etc.); institutional characteristics; use of negative } \\
\text { pressure rooms; availability of hand hygiene stations } \\
\text { HCW health (e.g., premorbid conditions/comorbidities) } \\
\text { Infection prevention and control factors: policies, use (including reuse), } \\
\text { training, adherence, availability, and type of personal protective equipment } \\
\text { or hand washing } \\
\text { KQ 3: Demographic characteristics, presence of symptoms, use of and type of } \\
\text { PPE, living circumstances (e.g. crowded housing, lack of separate rooms), } \\
\text { self-quarantine methods }\end{array}$ & Other exposures/risk factors \\
\hline Outcomes & $\begin{array}{l}\text { KQ 1: } \\
\text { SARS-CoV-2 infection: Incidence, morbidity and mortality, social and } \\
\text { economic effects of infection; and effects on family in exposed HCWs and } \\
\text { infected HCWs } \\
\text { SARS-CoV-1 and MERS-CoV infection: Infection and mortality in exposed } \\
\text { and infected HCWs } \\
\text { KQ 2: Risk estimates (relative risk, odds ratio, or hazard ratio) for incidence or } \\
\text { prevalence for risk factors; or incidence or prevalence reported by risk factor } \\
\text { KQ 3: Risk estimates and incidence of infections in household contacts of } \\
\text { infected HCWs }\end{array}$ & Other outcomes \\
\hline Study design & $\begin{array}{l}\text { Randomized, nonrandomized, and controlled clinical trials } \\
\text { Cohort studies } \\
\text { Case-control studies } \\
\text { Cross-sectional studies } \\
\text { Case series (KQ 1). }\end{array}$ & $\begin{array}{l}\text { Systematic reviews } \\
\text { (reference lists of relevant } \\
\text { reviews checked for } \\
\text { primary studies) } \\
\text { Case reports } \\
\text { Anecdotal reports } \\
\text { Modeling studies }\end{array}$ \\
\hline
\end{tabular}

$\mathrm{COV}=$ coronavirus; $\mathrm{HCW}=$ health care worker; ICU = intensive care unit; $\mathrm{KQ}=$ key question; $\mathrm{MERS}=$ Middle East respiratory syndrome; SARS = severe acute respiratory syndrome. 
Appendix Figure. Literature search and selection.

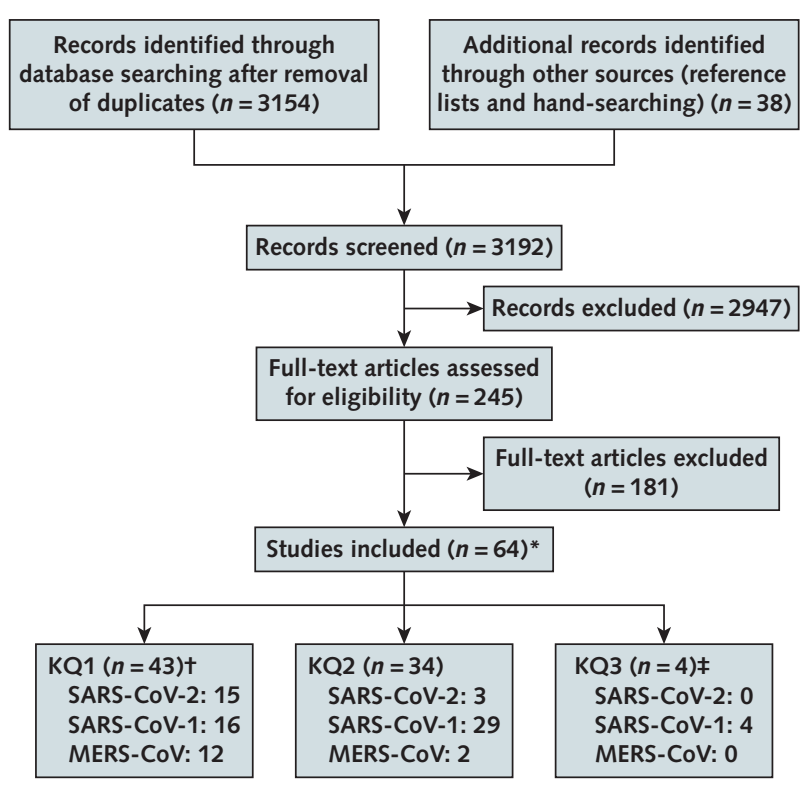

$\mathrm{CoV}$ = coronavirus; $\mathrm{KQ}=$ key question; MERS = Middle East respiratory syndrome; SARS = severe acute respiratory syndrome.

* Some studies were included for multiple KQs; includes 6 studies that were not peer-reviewed $(28,39,46,47,59,79)$ and 3 Chinese-language studies translated into English $(48,52,78)$.

† Data from 2 World Health Organization websites on the incidence of SARS-1 (81) and MERS (82) were also included.

$\ddagger$ Included in the full evidence review (10). 


\begin{tabular}{|c|c|c|c|c|c|}
\hline $\begin{array}{l}\text { Study, Year } \\
\text { (Reference) }\end{array}$ & Study Design & $\begin{array}{l}\text { Setting and Study } \\
\text { Dates }\end{array}$ & Population Characteristics & Outcomes & Limitations \\
\hline $\begin{array}{l}\text { Ran et al, } \\
2020(61)\end{array}$ & $\begin{array}{l}\text { Retrospective } \\
\text { cohort }\end{array}$ & $\begin{array}{l}\text { China (Wuhan); } 1 \\
\text { hospital serving } \\
\text { outbreak; follow-up } \\
\text { through } 28 \text { January } \\
2020\end{array}$ & $\begin{array}{l}72 \mathrm{HCWs} \text { with acute symptoms } \\
\text { - Median age, } 31 \text { y } \\
\text { - } 69 \% \text { female } \\
\text {-53\% clinicians and } 47 \% \\
\text { nurses }\end{array}$ & $\begin{array}{l}\text { Incidence of COVID-19: } 38.9 \% \\
(28 / 72)\end{array}$ & $\begin{array}{l}\text { No information on } \\
\text { clinical } \\
\text { outcomes of } \\
\text { COVID-19; } \\
\text { selection of } \\
\text { HCWs for } \\
\text { testing unclear }\end{array}$ \\
\hline $\begin{array}{l}\text { Dai et al, } \\
2020(28)\end{array}$ & Cross-sectional & $\begin{array}{l}\text { China (Hubei province); } \\
\text { HCWs from } \\
\text { throughout province; } \\
\text { 3-11 February } 2020\end{array}$ & $\begin{array}{l}4357 \mathrm{HCWs} \\
\text { - Mean age, } 35 \text { y } \\
\text { - } 76.5 \% \text { female } \\
\text { - } 32.6 \% \text { physicians, } 53.8 \% \\
\text { nurses, } 10.0 \% \text { technicians, } \\
3.6 \% \text { support staff } \\
\text { - } 0.9 \% \text { diagnosed with } \\
\text { COVID-19 }\end{array}$ & $\begin{array}{l}\text { GHQ-12 score } \geq 3: 39.1 \% \\
\text { (1704/4357) } \\
\text { Adjusted OR (95\% CI) for } \\
\text { GHQ-12 score } \geq 3 \\
\text { - Female vs. male: } 1.53 \\
\text { (1.26-1.85) } \\
\text { - Nurse vs. doctor: } 0.97 \\
\text { (0.81-1.15) } \\
\text { - Technician vs. doctor: } 0.73 \\
\text { (0.57-0.94) } \\
\text { - Support staff vs. doctor: } 0.80 \\
\text { (0.55-1.18) } \\
\text { - Hospital type (reference } \\
\text { ministerial/provincial) } \\
\text { O Municipal: } 1.45 \\
\text { (1.17-1.81) } \\
\text { O Country: } 1.71(1.30-2.23) \\
\text { O Township/community: } \\
\text { 1.46 (1.08-1.98) }\end{array}$ & $\begin{array}{l}\text { Not peer reviewed } \\
\text { No control for } \\
\text { baseline } \\
\text { symptoms; no } \\
\text { non-HCW } \\
\text { controls; no } \\
\text { control for work } \\
\text { exposures }\end{array}$ \\
\hline Kang, $2020(36)$ & Cross-sectional & $\begin{array}{l}\text { China (Wuhan); HCWs } \\
\text { from hospitals in } \\
\text { Wuhan; } 29 \text { January to } \\
4 \text { February } 2020\end{array}$ & $\begin{array}{l}\text { 994 HCWs } \\
\cdot 63.4 \% \text { aged } 25-40 \text { y } \\
\cdot 85 \% \text { female } \\
-31.1 \% \text { high-risk department } \\
\cdot 18.4 \% \text { physicians; } 81.6 \% \\
\text { nurses } \\
-1.9 \%(19 / 994) \text { positive for } \\
\text { SARS-CoV-2 infection }\end{array}$ & $\begin{array}{l}\text { Proportion classified into } \\
\text { moderate or severe mental } \\
\text { health disturbance clusters: } \\
\text { - Moderate: } 22.4 \% \text { (223/994) } \\
\text { o Mean depression (PHQ-9) } \\
\text { score: } 9.0 \text { (SD, 3.9) } \\
\text { o Mean anxiety (GAD-7) } \\
\text { score: } 8.2 \text { (SD, 3.6) } \\
\text { o Mean insomnia (ISI) score: } \\
\text { 10.4 (SD, 4.8) } \\
\text { o Mean distress (IES-R) } \\
\text { score: } 39.9 \text { (SD, 5.4) } \\
\text { - Severe: 6.2\% (62/994) } \\
\text { o Mean depression (PHQ-9) } \\
\text { score: } 15.1 \text { (SD, 5.2) } \\
\text { o Mean anxiety (GAD-7) } \\
\text { score: } 15.1 \text { (SD, 4.3) } \\
\text { o Mean insomnia (ISI) score: } \\
15.6 \text { (SD, } 5.2 \text { ) } \\
\text { o Mean distress (IES-R) } \\
\text { score: } 60.0 \text { (SD, 9.8) } \\
\text { No association between } \\
\text { increased risk for moderate } \\
\text { or severe mental health } \\
\text { disturbance and age, sex, } \\
\text { type of HCW or department }\end{array}$ & $\begin{array}{l}\text { Participation rate } \\
\text { not reported; } \\
\text { no control for } \\
\text { baseline } \\
\text { symptoms; no } \\
\text { non-HCW } \\
\text { controls }\end{array}$ \\
\hline $\begin{array}{l}\text { Kluytmans-van } \\
\text { den Berg et } \\
\text { al, } 2020 \text { (39) }\end{array}$ & Cross-sectional & $\begin{array}{l}\text { The Netherlands; } 2 \\
\text { hospitals; 7-12 March } \\
2020\end{array}$ & $\begin{array}{l}1853 \mathrm{HCWs} \text { with fever or mild } \\
\text { respiratory symptoms in past } \\
10 \mathrm{~d} \\
\text { - Median age, } 49 \text { y (cases) } \\
\text { - } 83 \% \text { female (cases) } \\
\text { - HCW role/position not } \\
\text { reported } \\
\text { - } 6.4 \%(86 / 1353) \text { positive for } \\
\text { SARS-CoV-2 infection }\end{array}$ & $\begin{array}{l}\text { Prevalence of SARS-CoV-2 } \\
\text { infection (PCR): } 6.4 \% \\
\text { ( } 86 / 1353 \text { ) } \\
\text { - Met case definition (fever } \\
\text { and/or coughing and/or } \\
\text { shortness of breath): } 91.9 \% \\
\text { ( } 79 / 86 \text { ) } \\
\text { - Recovery (by day of } \\
\text { interview): } 23.3 \% \text { (20/86), } \\
\text { median duration of illness } 8 \\
\text { days } \\
\text { - Admitted to hospital (not } \\
\text { critical): } 3.7 \%(2 / 86)\end{array}$ & $\begin{array}{l}\text { Not peer reviewed } \\
77 \% \text { not } \\
\text { recovered at } \\
\text { time of } \\
\text { interview }\end{array}$ \\
\hline
\end{tabular}

Continued on following page 


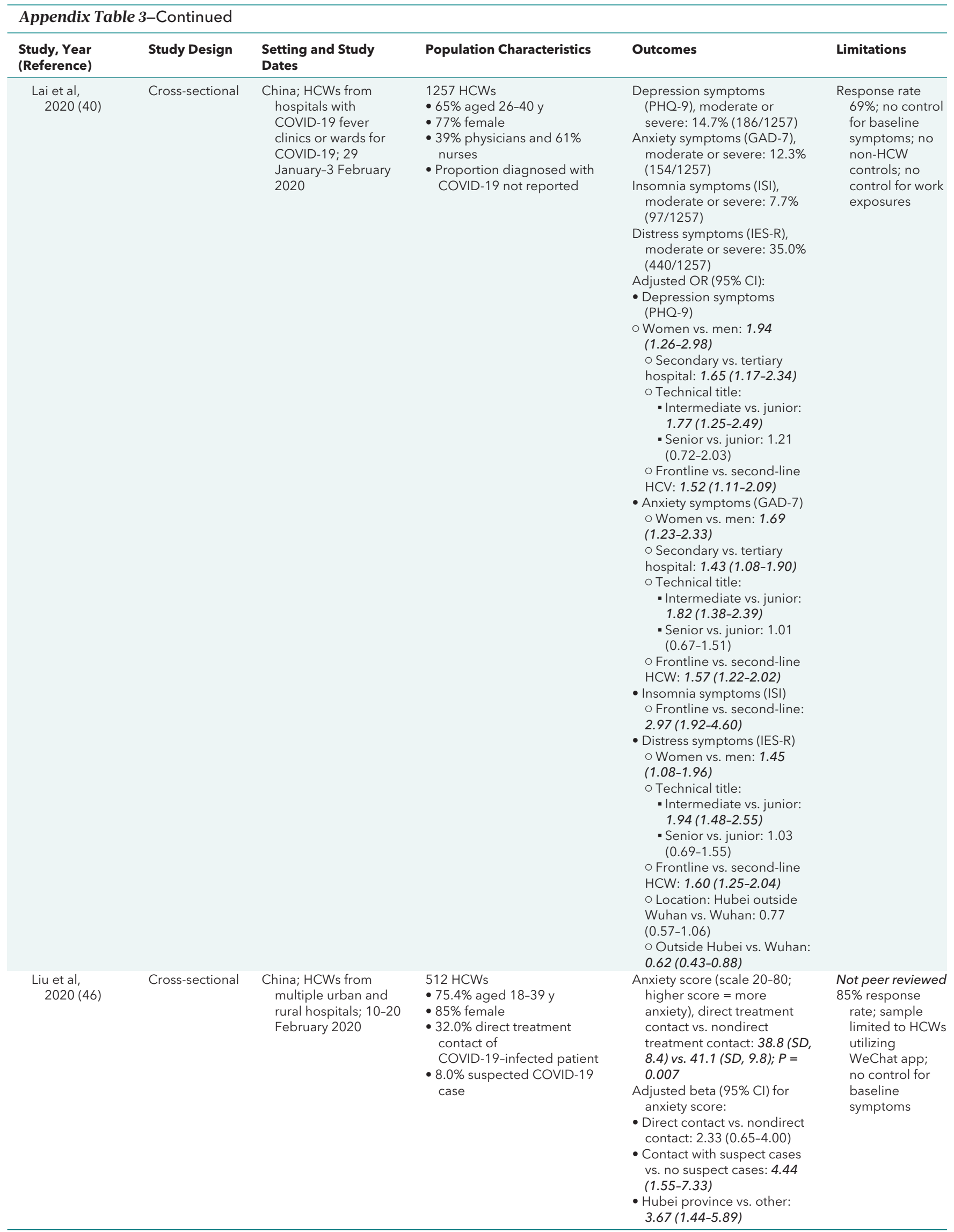




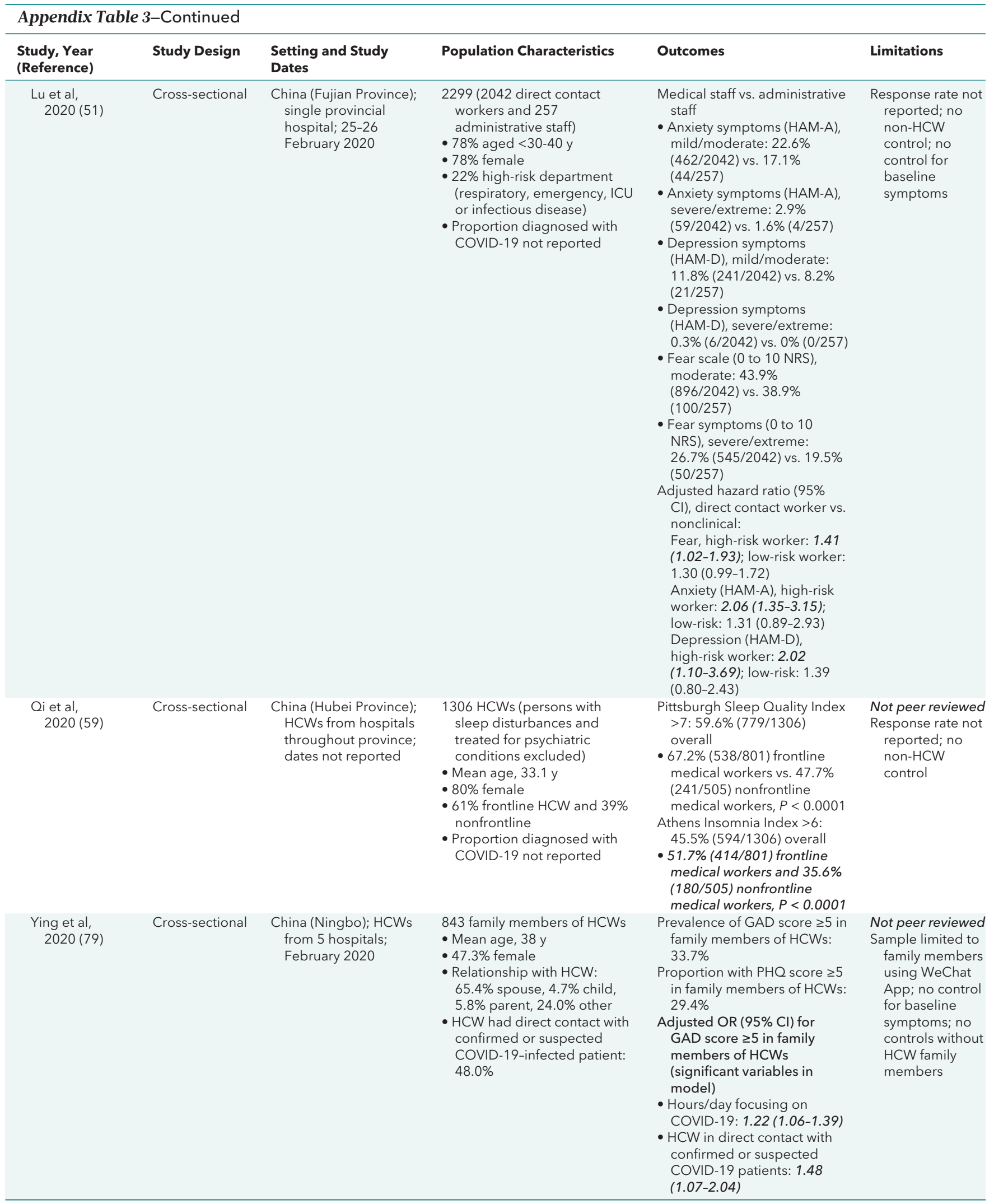




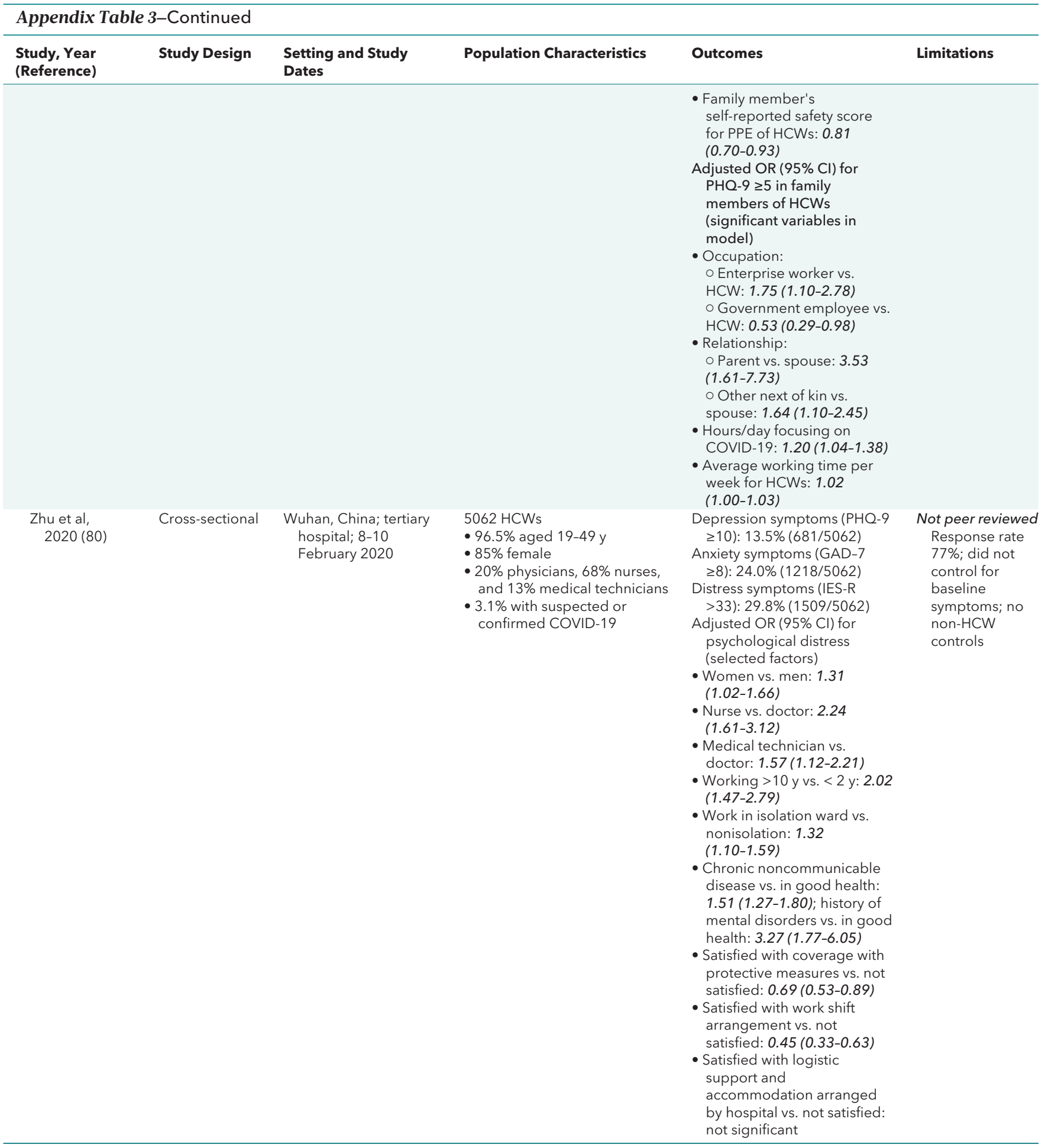

Continued on following page 


\begin{tabular}{|c|c|c|c|c|c|}
\hline \multicolumn{6}{|c|}{ Appendix Table 3-Continued } \\
\hline $\begin{array}{l}\text { Study, Year } \\
\text { (Reference) }\end{array}$ & Study Design & $\begin{array}{l}\text { Setting and Study } \\
\text { Dates }\end{array}$ & Population Characteristics & Outcomes & Limitations \\
\hline $\begin{array}{l}\text { McMichael et } \\
\text { al, } 2020 \text { (53) }\end{array}$ & Case series & $\begin{array}{l}\text { United States } \\
\text { (Washington); } 1 \\
\text { long-term care } \\
\text { facility; initial resident } \\
\text { case diagnosed } 28 \\
\text { February } 2020\end{array}$ & $\begin{array}{l}50 \text { HCWs with COVID-19 } \\
\text { (PCR-positive) } \\
\text { - Median age, } 43.5 \text { y } \\
\text { - } 76 \% \text { female } \\
\text { - Various (numbers not } \\
\text { reported) }\end{array}$ & $\begin{array}{l}29.9 \%(50 / 167) \text { of cases were } \\
\text { in HCWs } \\
\text { - Hospitalized: } 6.0 \%(3 / 50) \\
\text { - Mortality: } 0 \%(0 / 50)\end{array}$ & $\begin{array}{l}\text { No denominator } \\
\text { for the total } \\
\text { number of } \\
\text { exposed HCWs; } \\
\text { proportion } \\
\text { recovered at } \\
\text { time of study } \\
\text { not reported }\end{array}$ \\
\hline
\end{tabular}




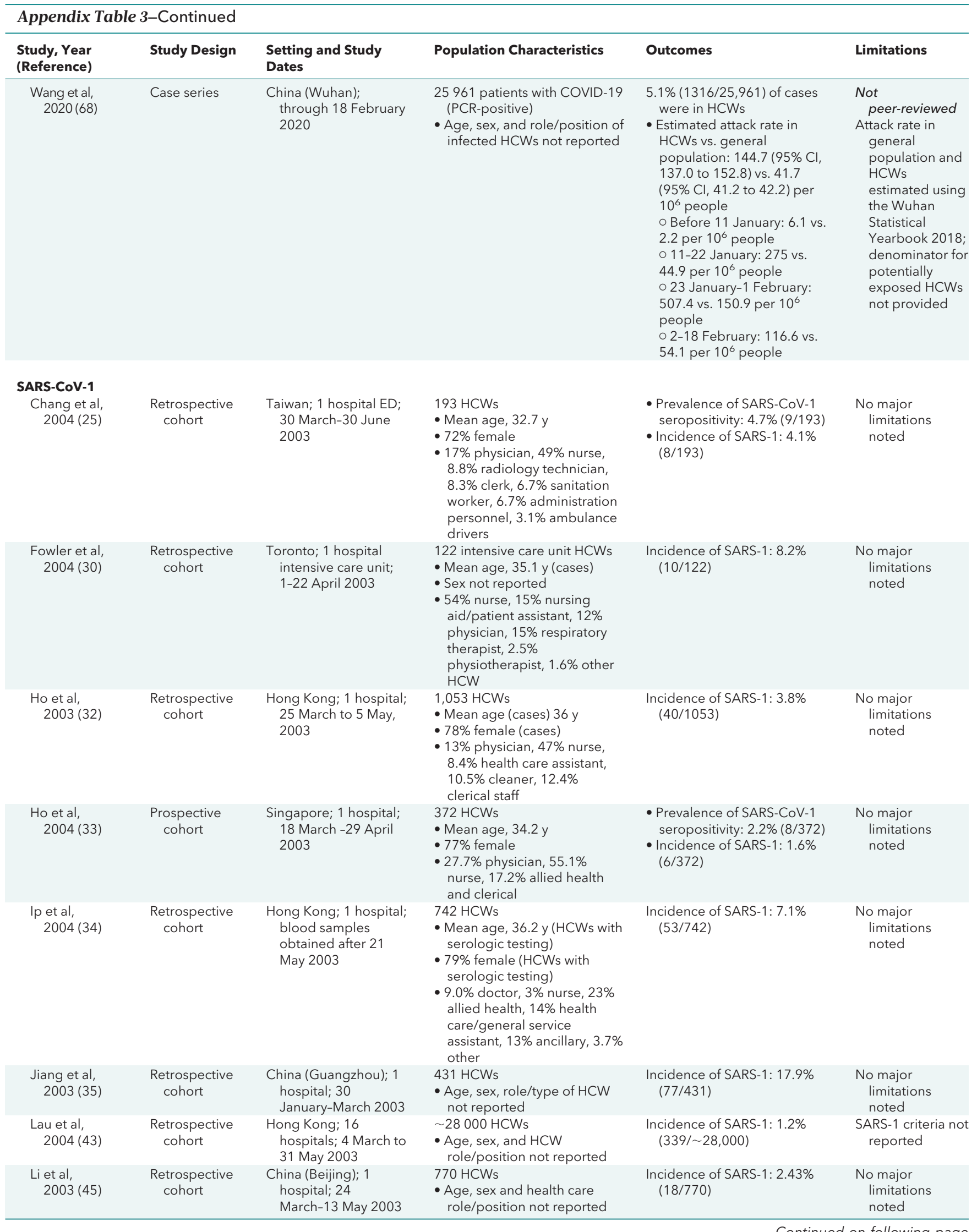




\begin{tabular}{|c|c|c|c|c|c|}
\hline \multicolumn{6}{|c|}{ Appendix Table 3-Continued } \\
\hline $\begin{array}{l}\text { Study, Year } \\
\text { (Reference) }\end{array}$ & Study Design & $\begin{array}{l}\text { Setting and Study } \\
\text { Dates }\end{array}$ & Population Characteristics & Outcomes & Limitations \\
\hline $\begin{array}{l}\text { Nishiyama et al, } \\
2008 \text { (57) }\end{array}$ & $\begin{array}{l}\text { Retrospective } \\
\text { cohort }\end{array}$ & $\begin{array}{l}\text { Vietnam (Hanoi); two } \\
\text { hospitals; exposure } \\
\text { 3-17 March } 2003\end{array}$ & $\begin{array}{l}146 \mathrm{HCWs} \\
\text { - Age, sex, and HCW } \\
\text { role/position not reported }\end{array}$ & $\begin{array}{l}\text { Prevalence of SARS-CoV-1 } \\
\text { seropositivity: } 40.4 \% \\
(59 / 146) \\
\text { Incidence of SARS-1: } 29.4 \% \\
(43 / 146)\end{array}$ & $\begin{array}{l}\text { No major } \\
\text { limitations } \\
\text { noted }\end{array}$ \\
\hline $\begin{array}{l}\text { Raboud et al, } \\
2010(60)\end{array}$ & $\begin{array}{l}\text { Retrospective } \\
\text { cohort }\end{array}$ & $\begin{array}{l}\text { Canada (Toronto); } 20 \\
\text { hospitals; } 5 \text { March-12 } \\
\text { June } 2003\end{array}$ & $\begin{array}{l}624 \mathrm{HCW} \text { provided care to } \\
\text { intubated SARS-1 patients } \\
\text { - Mean age } 38.5 \text { y (cases) } \\
\text { - } 75.2 \% \text { female } \\
\text { - } 12.3 \% \text { staff physician, } 2.6 \% \\
\text { medical resident/intern, } \\
45.4 \% \text { registered nurse, } \\
14.3 \% \text { respiratory therapist, } \\
10.7 \% \text { radiology } \\
\text { technologist, } 6.1 \% \\
\text { housekeeper, } 4.2 \% \text { personal } \\
\text { service assistant, } 2.2 \% \\
\text { laboratory } \\
\text { technician/technologist, } \\
\text { 0.5\% EMT; } 1.8 \% \text { other }\end{array}$ & $\begin{array}{l}\text { Prevalence of SARS-CoV-1 } \\
\text { seropositivity: } 4.2 \%(26 / 624)\end{array}$ & $\begin{array}{l}\text { SARS-1 diagnosis } \\
\text { did not require } \\
\text { laboratory } \\
\text { confirmation }\end{array}$ \\
\hline $\begin{array}{l}\text { Scales et al, } \\
2003(64)\end{array}$ & $\begin{array}{l}\text { Retrospective } \\
\text { cohort }\end{array}$ & $\begin{array}{l}\text { Canada (Toronto); } \\
\text { single hospital } \\
\text { intensive care unit; } \\
\text { exposure occurred } \\
23 \text { March } 2003\end{array}$ & $\begin{array}{l}69 \mathrm{HCW} \text { with brief, } \\
\text { unexpected exposure to } \\
\text { SARS-1-infected patient } \\
\text { - Age, sex, HCW role/position } \\
\text { not reported }\end{array}$ & $\begin{array}{l}\text { Incidence of SARS-1: } 10.1 \% \\
(7 / 69)\end{array}$ & $\begin{array}{l}\text { No major } \\
\text { limitations } \\
\text { noted }\end{array}$ \\
\hline $\begin{array}{l}\text { Wang et al, } \\
2007 \text { (69) }\end{array}$ & $\begin{array}{l}\text { Retrospective } \\
\text { cohort }\end{array}$ & $\begin{array}{l}\text { Taiwan; } 4 \text { hospitals; } \\
\text { study began } 1 \text { July } \\
2003\end{array}$ & $\begin{array}{l}2512 \mathrm{HCWs} \\
\text { - Mean age, } 33.4 \text { y } \\
\text { - } 88 \% \text { female } \\
\text { - } 13 \% \text { physician, } 83 \% \text { nurse } \\
\text { - } 0.36 \%(9 / 2512) \text { seropositive } \\
\text { for SARS-CoV- } 1 ; 1.0 \% \\
\text { ( } 9 / 882 \text { ) among those } \\
\text { reporting contact with } \\
\text { SARS-1 patients }\end{array}$ & $\begin{array}{l}\text { Prevalence of seropositivity to } \\
\text { SARS-CoV-1: } 0.3 \%(9 / 2512) \\
1.0 \%(9 / 882) \text { among those } \\
\text { reporting contact with } \\
\text { SARS-1 patients }\end{array}$ & $\begin{array}{l}\text { No major } \\
\text { limitations } \\
\text { noted }\end{array}$ \\
\hline $\begin{array}{l}\text { Chen et al, } \\
2005 \text { (27) }\end{array}$ & Cross-sectional & $\begin{array}{r}\text { China (Guangzhou); } 3 \\
\text { hospitals; May } 2003\end{array}$ & $\begin{array}{l}\text { 1856 HCWs ( } 1135 \text { worked with } \\
\text { SARS patients) } \\
\text { - Mean age, } 30.8 \text { y } \\
\text { - } 71.6 \% \text { female } \\
\text { - } 30.7 \% \text { doctor, } 48.3 \% \text { nurse, } \\
5.5 \% \text { health attendant, } 4.0 \% \\
\text { laboratory technician, } 11.5 \% \\
\text { other }\end{array}$ & $\begin{array}{l}\text { - Prevalence of SARS-CoV-1 } \\
\text { seropositivity among HCWs } \\
\text { who worked with SARS } \\
\text { patients: } 8.3 \% \text { (95/1147) } \\
\text { - Incidence of SARS-1: } 7.8 \% \\
\text { (90/1147) }\end{array}$ & $\begin{array}{l}10 \text { patients with } \\
\text { SARS-1 were } \\
\text { SARS-CoV-1 } \\
\text { seronegative }\end{array}$ \\
\hline $\begin{array}{l}\text { Leung et al, } \\
2004(44)\end{array}$ & Case series & $\begin{array}{l}\text { Hong Kong; All cases } \\
2003 \text { outbreak }\end{array}$ & $\begin{array}{l}1755 \text { SARS- } 1 \text { cases ( } 405 \\
\text { HCWs) } \\
\text {-48\% aged } \leq 39 \text { y of age, 30\% } \\
\text { aged } 40-59 \text { y (all cases) } \\
-55.7 \% \text { female (all cases) } \\
15.8 \% \text { physician, } 51.9 \% \\
\text { nurse, } 28.4 \% \text { other, } 4.0 \% \\
\text { medical students }\end{array}$ & $\begin{array}{l}\text { 23.1\% ( } 405 / 1755) \text { of cases } \\
\text { were in HCWs } \\
\text { Mortality: } 2.0 \%(8 / 405) \\
\text { - Physician: } 6.2 \%(4 / 64) \\
\text { - Nurse: } 0.5 \%(1 / 210) \\
\text { - Medical student: } 0 \%(0 / 16) \\
\text { - Other HCW: } 2.6 \%(3 / 115) \\
\text { Adjusted OR }(95 \% \mathrm{Cl}) \text { for } \\
\text { mortality } \\
\text { - HCW vs. non-HCW: } 0.30 \\
\text { (0.1-0.7) }\end{array}$ & $\begin{array}{l}288 \text { cases without } \\
\text { laboratory } \\
\text { confirmation; } \\
\text { based on } \\
\text { studies with } \\
\text { laboratory } \\
\text { confirmation, } \\
\text { adjusted OR for } \\
\text { mortality for } \\
\text { HCW vs. } \\
\text { non-HCW } 0.6 \\
(95 \% \mathrm{Cl}, \\
0.2-1.3)\end{array}$ \\
\hline
\end{tabular}

Continued on following page 


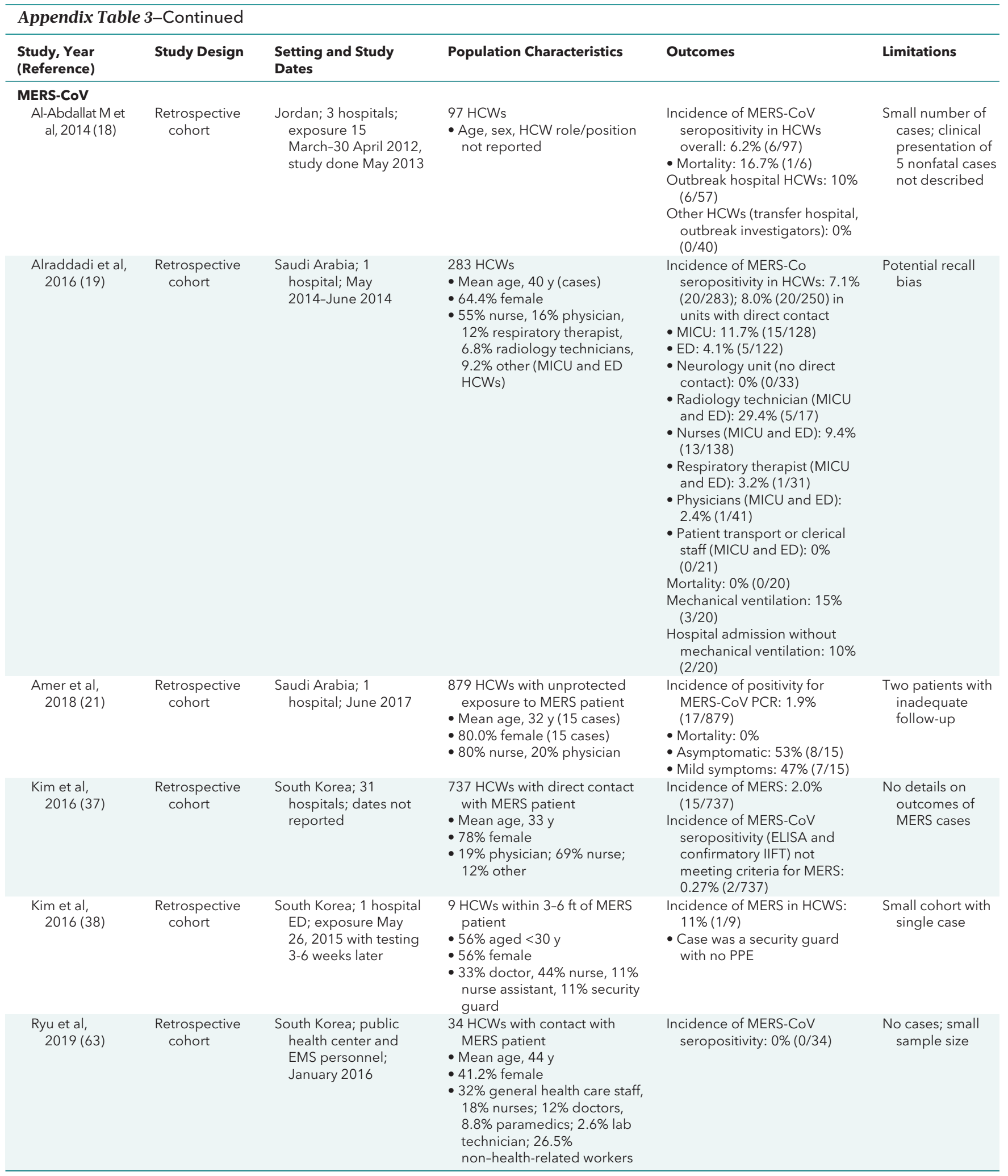




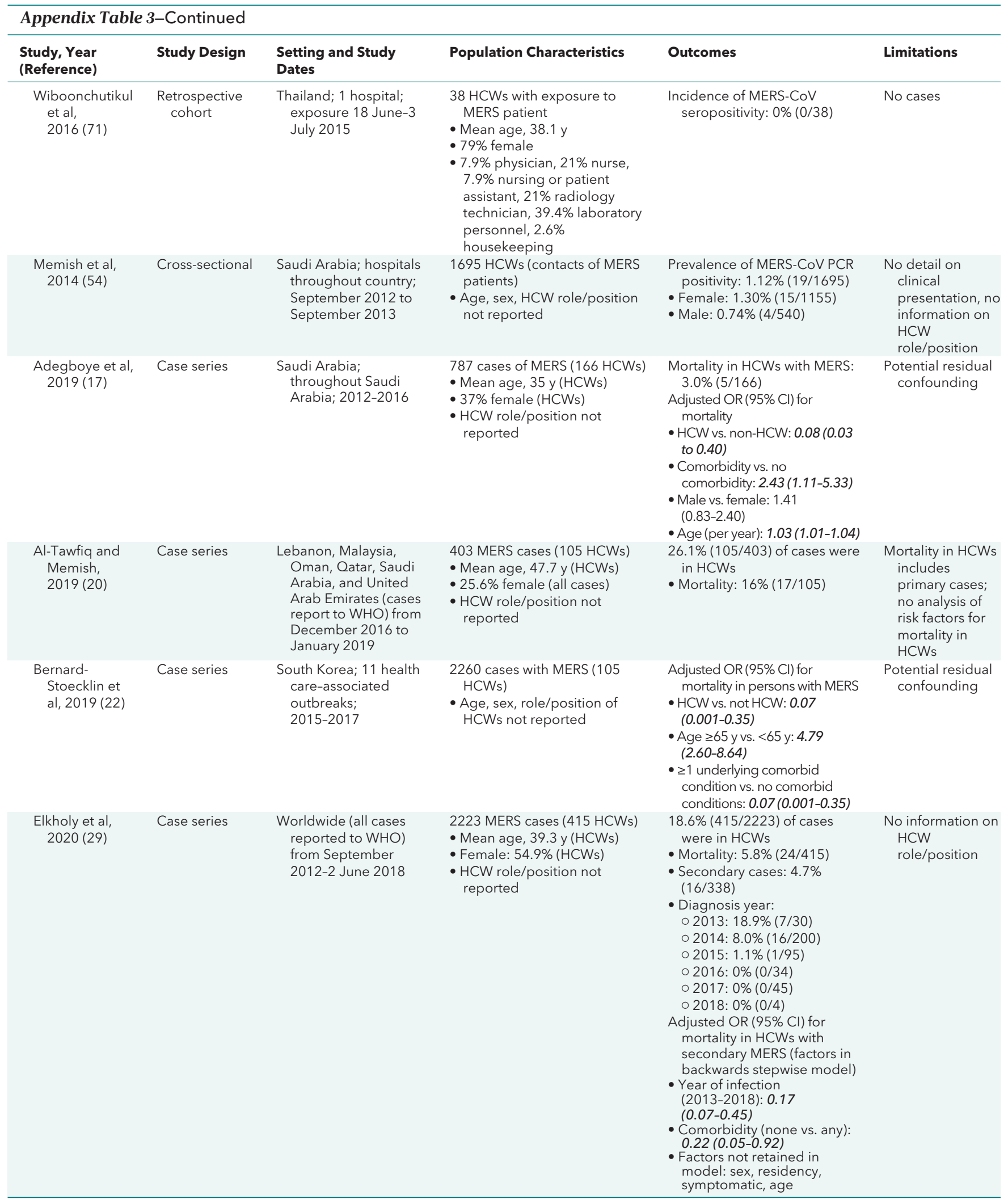

$\mathrm{BMI}=$ body mass index; CoV = coronavirus; COVID-19 = coronavirus disease 2019; ED = emergency department; EMT = emergency medical technician; $\mathrm{GAD}=$ generalized anxiety disorder; $\mathrm{GHQ}=$ General Health Questionnaire; HAM-A = Hamilton Anxiety Scale; HAM-D = Hamilton Depression Scale; HCW = health care worker; IES-R = Impact of Event Scale-Revised; IL = interleukin; ISI = Insomnia Severity Index; MERS = Middle East respiratory syndrome; $\mathrm{MICU}=$ medical intensive care unit; $\mathrm{NRS}=$ numeric rating scale; $\mathrm{PCR}=$ polymerase chain reaction; $\mathrm{PHQ}=\mathrm{Patient} \mathrm{Health}$ Questionnaire; PPE = personal protective equipment; SARS = severe acute respiratory syndrome; WHO = World Health Organization.

* Values in boldface and italics indicate a statistically significant difference between groups. 


\begin{tabular}{|c|c|c|}
\hline \multicolumn{3}{|c|}{ SARS-1, 1 November 2002-31 July 2003 (81) } \\
\hline China & 5327 & $1002(19)$ \\
\hline China, Hong Kong & 1755 & $386(22)$ \\
\hline China, Taiwan & 346 & $68(20)$ \\
\hline Singapore & 238 & $97(41)$ \\
\hline \multicolumn{3}{|l|}{ MERS (82) } \\
\hline Saudi Arabia, 2012-2019 & 2106 & 402 (19) \\
\hline Globally, July-December 2014 & 100 & $14(14)$ \\
\hline Globally, July-December 2015 & 257 & $46(18)$ \\
\hline Globally, July-December 2016 & 99 & $6(6)$ \\
\hline Globally, July-December 2017 & 94 & $9(8)$ \\
\hline
\end{tabular}

$\mathrm{HCW}=$ health care worker; MRS = Middle East respiratory syndrome; SARS = severe acute respiratory syndrome.

* Includes countries with <50 cases not shown in table. 


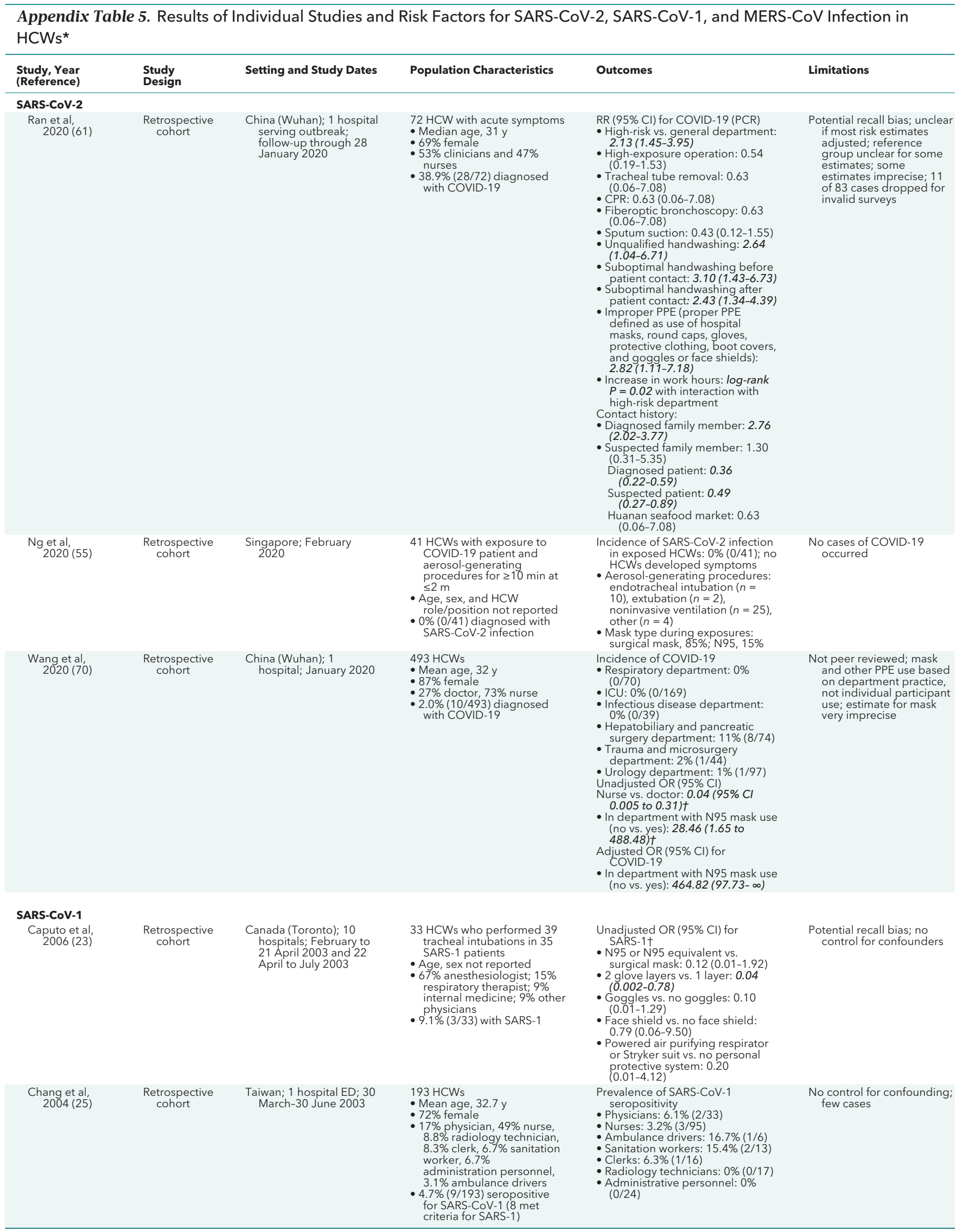




\begin{tabular}{|c|c|c|c|c|c|}
\hline \multicolumn{6}{|c|}{ Appendix Table 5-Continued } \\
\hline $\begin{array}{l}\text { Study, Year } \\
\text { (Reference) }\end{array}$ & $\begin{array}{l}\text { Study } \\
\text { Design }\end{array}$ & Setting and Study Dates & Population Characteristics & Outcomes & Limitations \\
\hline $\begin{array}{l}\text { Fowler et al, } \\
2004(30)\end{array}$ & $\begin{array}{l}\text { Retrospective } \\
\text { cohort }\end{array}$ & $\begin{array}{l}\text { Toronto; } 1 \text { hospital } \\
\text { intensive care unit; } \\
\text { 1-22 April } 2003\end{array}$ & $\begin{array}{l}122 \text { intensive care unit HCWs } \\
\text { - Mean age, } 35.1 \text { y y (cases) } \\
\text { Sex not reported } \\
\text { - } 54 \% \text { nurse, } 15 \% \text { nursing } \\
\text { aid/patient assistant, } 12 \% \\
\text { physician, } 15 \% \text { respiratory } \\
\text { therapist, } 2.5 \% \\
\text { physiotherapist, } 1.6 \% \text { other } \\
\text { HCW } \\
\text { - } 8.2 \% \text { (10/122) diagnosed } \\
\text { with SARS-1 }\end{array}$ & $\begin{array}{l}\text { Incidence of SARS-1 } \\
\text { - Physicians: } 16.7 \% \text { ( } 3 / 18) \\
\text { - Nurses: } 7.6 \% \text { (5/66) } \\
\text { - Respiratory therapist: } 11.1 \% \\
\text { ( } 2 / 18) \\
\text { Unadjusted RR ( } 95 \% \text { CI) for SARS-1 } \\
\text { - Any involvement in intubation vs. } \\
\text { no involvememt, physician or } \\
\text { nurse: } 13.29 \text { (2.99-59.04) } \\
\text { o Nurse: } 21.38 \text { ( } 4.89 .93 .37) \\
\text { O Physician: } 3.82(0.23-62.24) \\
\text { - Cared for patient treated with } \\
\text { noninvasive positive pressure vs. } \\
\text { conventiona ventilation } \\
\text { (restricted to nurses): } 2.33 \\
\text { (0.25-21.76) } \\
\text { - Cared for patient treated with } \\
\text { high frequency oscillatory vs. } \\
\text { conventional ventilation } \\
\text { (restricted to nurses): } 0.74 \\
\text { (0.11-4.92) }\end{array}$ & $\begin{array}{l}\text { No control for confounding; } \\
\text { some estimates } \\
\text { imprecise }\end{array}$ \\
\hline $\begin{array}{l}\text { Ho et al, } \\
2004 \text { (33) }\end{array}$ & $\begin{array}{l}\text { Prospective } \\
\text { cohort }\end{array}$ & $\begin{array}{l}\text { Singapore; } 1 \text { hospital; } 18 \\
\text { March-29 April } 2003\end{array}$ & $\begin{array}{l}372 \text { HCWs } \\
\text {. Mean age, } 34.2 \text { y } \\
777 \% \text { female } \\
27.7 \% \text { physician, } 55.1 \% \\
\text { nurse, } 17.2 \% \text { allied health } \\
\text { and clerical } \\
-2.2 \% \text { ( } 8 / 372 \text { ) seropositive } \\
\text { for SARS-CoV-1.6 met } \\
\text { criteria for SARS- } 1\end{array}$ & $\begin{array}{l}\text { RR ( } 95 \% \text { CI) for SARS-CoV-1 } \\
\text { seropositivity } \\
\text { - Exposure only vs. direct contact: } \\
2.40 \text { ( } 0.64-9.00 \text { ) } \\
\text { - Protected direct contact vs. } \\
\text { unprotected direct contact: } 0.16 \\
\text { ( } 0.03-1.02) \\
\text { - Use of full PPE } 100 \% \text { of the time } \\
\text { vs. }<100 \% \text { of the time: } 0.19 \\
(0.02-1.49)\end{array}$ & $\begin{array}{l}\text { No control for confounding; } \\
\text { few cases with imprecise } \\
\text { estimates }\end{array}$ \\
\hline $\begin{array}{l}\text { Ip et al, } \\
2004 \text { (34) }\end{array}$ & $\begin{array}{l}\text { Retrospective } \\
\text { cohort }\end{array}$ & $\begin{array}{l}\text { Hong Kong; } 1 \text { hospital; } \\
\text { blood samples } \\
\text { obtained after } 21 \text { May } \\
2003\end{array}$ & $\begin{array}{l}742 \mathrm{HCWs} \\
\text { - Mean age, } 36.2 \text { y (HCWs } \\
\text { with serologic testing) } \\
\text { - } 79 \% \text { female ( } \mathrm{HCW} \text { s with } \\
\text { serologic testing) } \\
\text { - } 9.0 \% \text { doctor, } 3 \% \text { nurse, } 23 \% \\
\text { allied health, } 14 \% \text { health } \\
\text { care/general service } \\
\text { assistant, } 13 \% \text { ancillary, } \\
3.7 \% \text { other } \\
\text { - } 7.1 \% \text { (53/742) diagnosed } \\
\text { with SARS-1 }\end{array}$ & $\begin{array}{l}\text { Incidence of SARS-1 } \\
\text { - Doctors: } 2.4 \%(2 / 85) \\
\text { - Nurses: } 11.6 \%(38 / 328) \\
\text { - Allied health: } 0.9 \%(1 / 114) \\
\text { - Health care/general service } \\
\text { assistants: } 11.8 \%(12 / 102) \\
\text { - Ancillary: } 0 \%(0 / 113) \\
\text { - Other: } 0 \%(0 / 12)\end{array}$ & No control for confounding \\
\hline $\begin{array}{l}\text { Lau et al, } \\
2004(43)\end{array}$ & $\begin{array}{l}\text { Retrospective } \\
\text { cohort }\end{array}$ & $\begin{array}{l}\text { Hong Kong; } 16 \text { hospitals; } \\
4 \text { March-31 May } 2003\end{array}$ & $\begin{array}{l}\sim 28000 \mathrm{HCWs} \\
\text { Age, sex, and HCW } \\
\text { role/position not reported } \\
1.2 \% \text { ( } 339 \text { ) diagnosed with } \\
\text { SARS- } 1\end{array}$ & $\begin{array}{l}\text { Mean attack rate (SD) for SARS-1 } \\
\text { across } 16 \text { hospitals: overall: } \\
1.06 \% \text { (SD } 1.31 \text { ) } \\
\text { - Nurse: } 1.07 \% \text { (SD } 1.38 \text { ) } \\
\text { Nonmedical support staff: } 2.34 \% \\
\text { (SD 3.43) } \\
\text { Other technical and medical staff: } \\
\text { 0.32\% (SD 0.49); } P=0.035 \text { for } \\
\text { job category }\end{array}$ & $\begin{array}{l}\text { No control for confounding; } \\
\text { SARS-1 criteria not } \\
\text { reported }\end{array}$ \\
\hline $\begin{array}{l}\text { Li et al, } \\
\quad 2003 \text { (45) }\end{array}$ & $\begin{array}{l}\text { Retrospective } \\
\text { cohort }\end{array}$ & $\begin{array}{l}\text { China (Beijing); } 1 \\
\text { hospital; } 24 \text { March-13 } \\
\text { May } 2003\end{array}$ & $\begin{array}{l}770 \mathrm{HCWs} \\
\text { - Age, sex and HCW } \\
\text { role/position not reported } \\
\text {-2.43\% (18/770) diagnosed } \\
\text { with SARS-1 }\end{array}$ & $\begin{array}{l}\text { Incidence of SARS-1 } \\
\text { - Doctor: } 2.88 \% \\
\text { - Nurse: } 4.78 \% \\
\text { - Nursing assistant: } 6.67 \% \\
\text { - Other hospital staff: } 0 \%\end{array}$ & $\begin{array}{l}\text { No control for confounding; } \\
\text { few SARS-1 cases; } \\
\text { number of HCWs in } \\
\text { different roles/positions } \\
\text { not reported }\end{array}$ \\
\hline
\end{tabular}

Continued on following page 


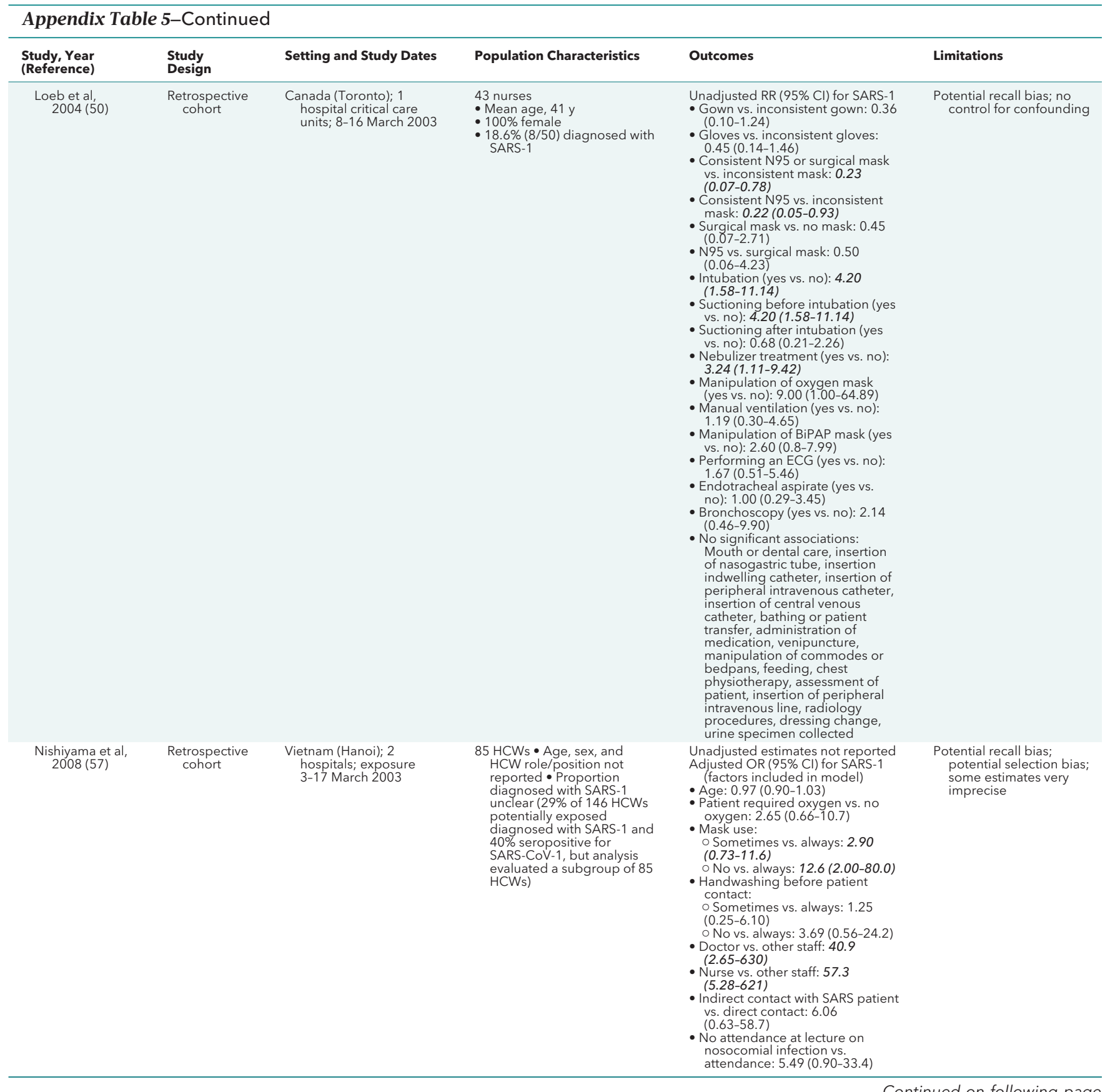

Continued on following page 


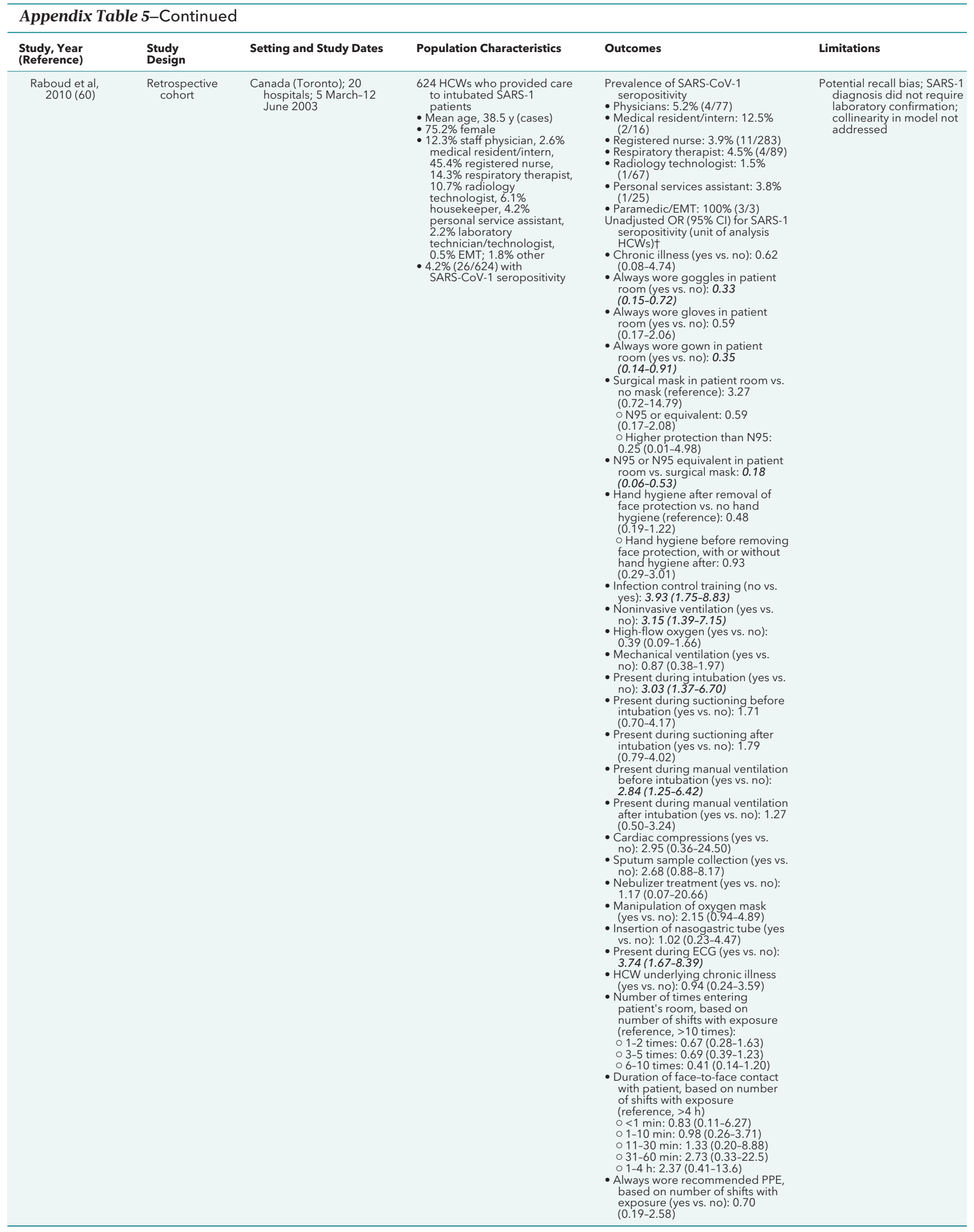

Continued on following page 


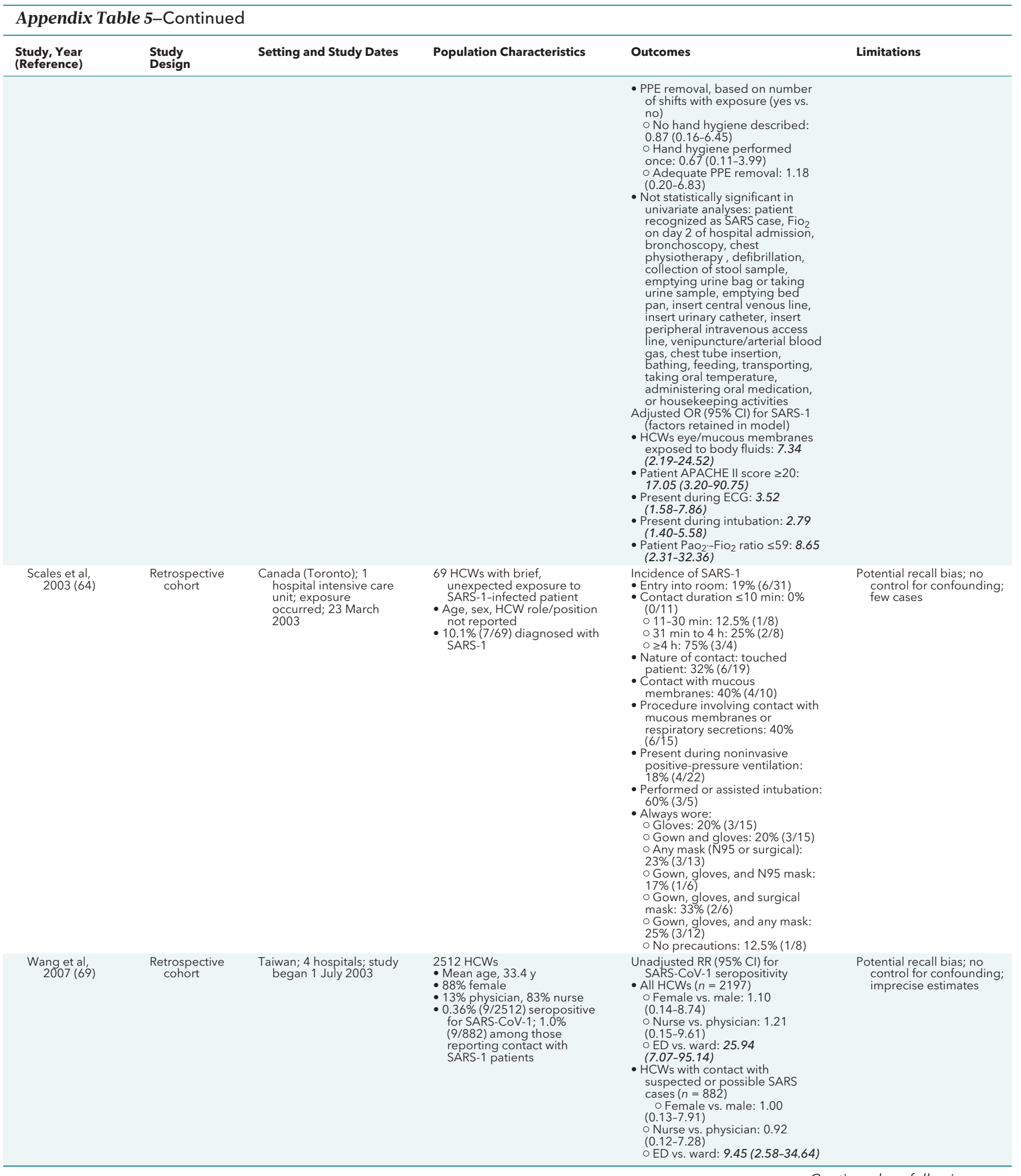

Continued on following page 


\begin{tabular}{|c|c|c|c|c|c|}
\hline \multicolumn{6}{|c|}{ Appendix Table 5-Continued } \\
\hline $\begin{array}{l}\text { Study, Year } \\
\text { (Reference) }\end{array}$ & $\begin{array}{l}\text { Study } \\
\text { Design }\end{array}$ & Setting and Study Dates & Population Characteristics & Outcomes & Limitations \\
\hline $\begin{array}{l}\text { Wilder-Smith et } \\
\text { al, } 2005 \text { (72) }\end{array}$ & $\begin{array}{l}\text { Retrospective } \\
\text { cohort }\end{array}$ & $\begin{array}{l}\text { Singapore; } 1 \text { hospital; } \\
\text { March } 2003\end{array}$ & $\begin{array}{l}98 \text { HCWs ( } 80 \text { with serologic } \\
\text { testing) } \\
\text { - Median age, } 28 \text { y } \\
\text { - } 91 \% \text { female } \\
\text { - } 10 \% \text { doctor, } 77.5 \%, 12.5 \% \\
\text { other } \\
\text { - } 45.9 \% \text { ( } 45 / 98 \text { ) with } \\
\text { SARS-CoV- } 1 \text { infection ( } 37 \\
\text { cases pneumonia, } 2 \text { cases } \\
\text { subclinical, and } 6 \text { cases } \\
\text { asymptomatic) }\end{array}$ & $\begin{array}{l}\text { Unadjusted OR ( } 95 \% \text { Cl) for } \\
\text { SARS-CoV- } 1 \text { infectiont } \\
\text { - Female vs. male: } 0.47(0.10-2.07) \\
\text { - Mask use vs. no mask use: } 0.25 \\
\text { ( } 0.09-0.69) \\
\text { - Glove use vs. no glove use: } 0.40 \\
\text { ( } 0.17-0.96) \\
\text { - Handwashing vs. no } \\
\text { handwashing: } 0.35 \text { ( } 0.11-1.12) \\
\text { - Close contact with SARS-1 } \\
\text { patient (yes vs. no): } 1.11 \\
\text { (0.23-5.26) } \\
\text { Mean age: } 29.2 \text { y in cases vs. } 33.7 \\
\text { in controls; } P=0.04\end{array}$ & $\begin{array}{l}\text { Potential recall bias, no } \\
\text { control for confounders; } \\
\text { analyses appear to } \\
\text { exclude } 2 \text { patients with } \\
\text { subclinical SARS-1 }\end{array}$ \\
\hline $\begin{array}{l}\text { Wong et al, } \\
2004 \text { (75) }\end{array}$ & $\begin{array}{l}\text { Retrospective } \\
\text { cohort }\end{array}$ & $\begin{array}{l}\text { Hong Kong; } 1 \text { hospital; } \\
\text { 4-10 March } 2003\end{array}$ & $\begin{array}{l}66 \text { medical students } \\
\text { - Mean age, } 22.3 \text { y (cases) } \\
\cdot 50 \% \text { female (cases) } \\
\text { - } 24 \% \text { (16/66) diagnosed with } \\
\text { SARS-1 }\end{array}$ & $\begin{array}{l}\text { Unadjusted RR (95\% CI) for SARS-1 } \\
\text { - Definitely visited patient's cubicle } \\
\text { vs. did not: } 7.4(1.0-53.5) \\
\text { - Association between distance } \\
\text { from patient and likelihood of } \\
\text { infection being present }\end{array}$ & $\begin{array}{l}\text { Potential recall bias; no } \\
\text { control for confounding }\end{array}$ \\
\hline $\begin{array}{l}\text { Chen et al, } \\
2009(26)\end{array}$ & Case-control & $\begin{array}{l}\text { China (Guangzhou); } 2 \\
\text { hospitals; dates not } \\
\text { reported }\end{array}$ & $\begin{array}{l}\text { 91 HCW cases with } \\
\text { SARS-CoV- } 1 \text { seropositivity } \\
\text { (80 SARS- } 1 \text { ) and } 657 \\
\text { controls } \\
-34.9 \% \text { aged }<26 \text { y, } 54.2 \% \\
26-40 \text { y, } 10.8 \%>50 \text { y } \\
\text { - } 76.0 \% \text { emale } \\
-31.5 \% \text { doctor, } 49.2 \% \text { nurse, } \\
7.3 \% \text { health attendant, } \\
5.0 \% \text { laboratory technician, } \\
7.0 \% \text { other }\end{array}$ & 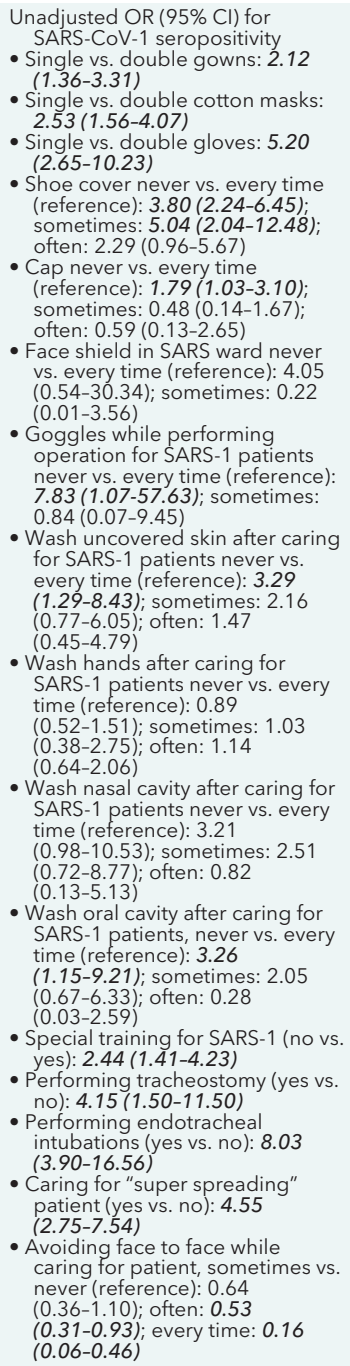 & $\begin{array}{l}\text { Potential recall bias; } \\
\text { methods for selecting } \\
\text { controls unclear; } \\
\text { collinearity in model not } \\
\text { addressed }\end{array}$ \\
\hline
\end{tabular}




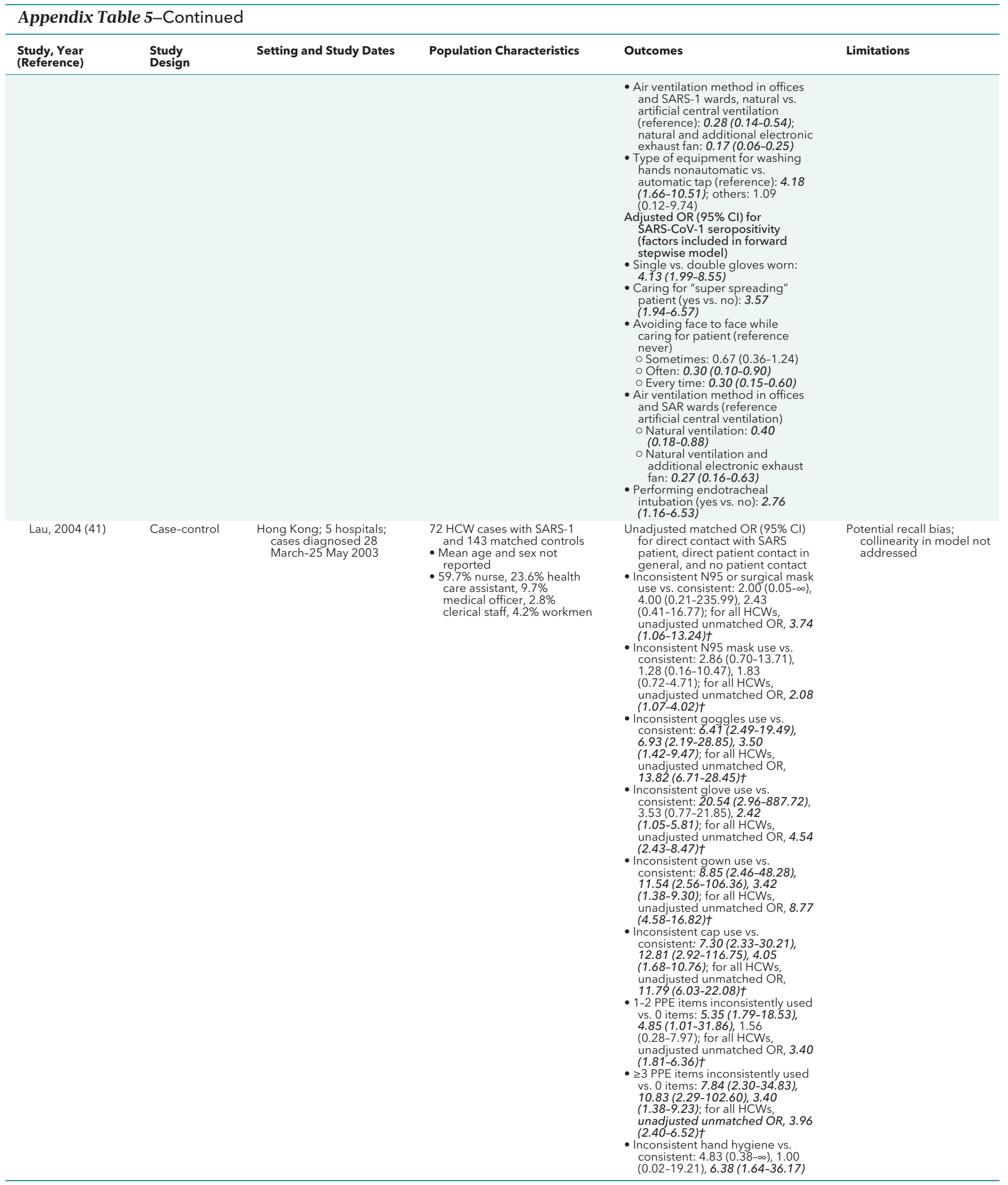

Continued on following page 


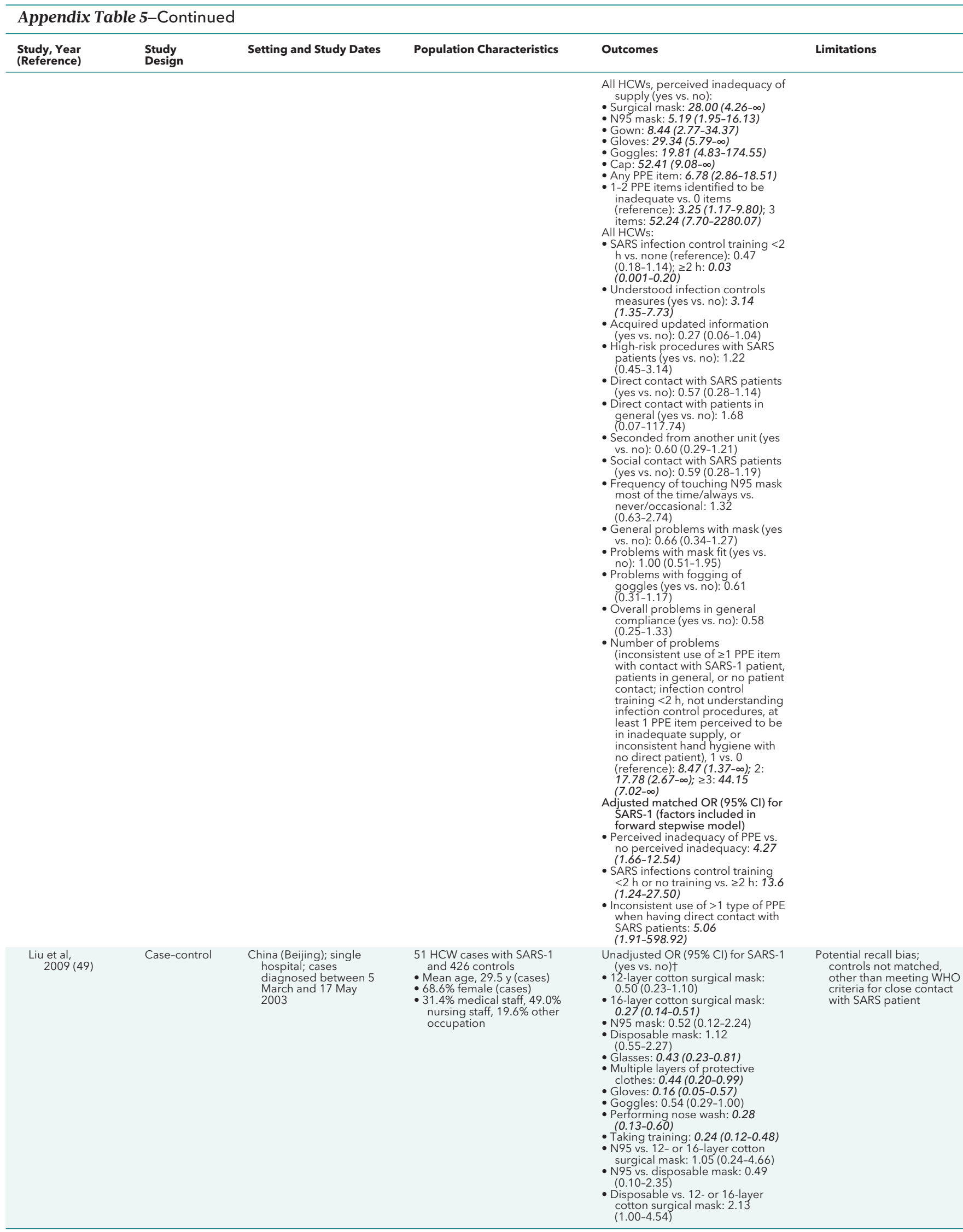

Continued on following page 


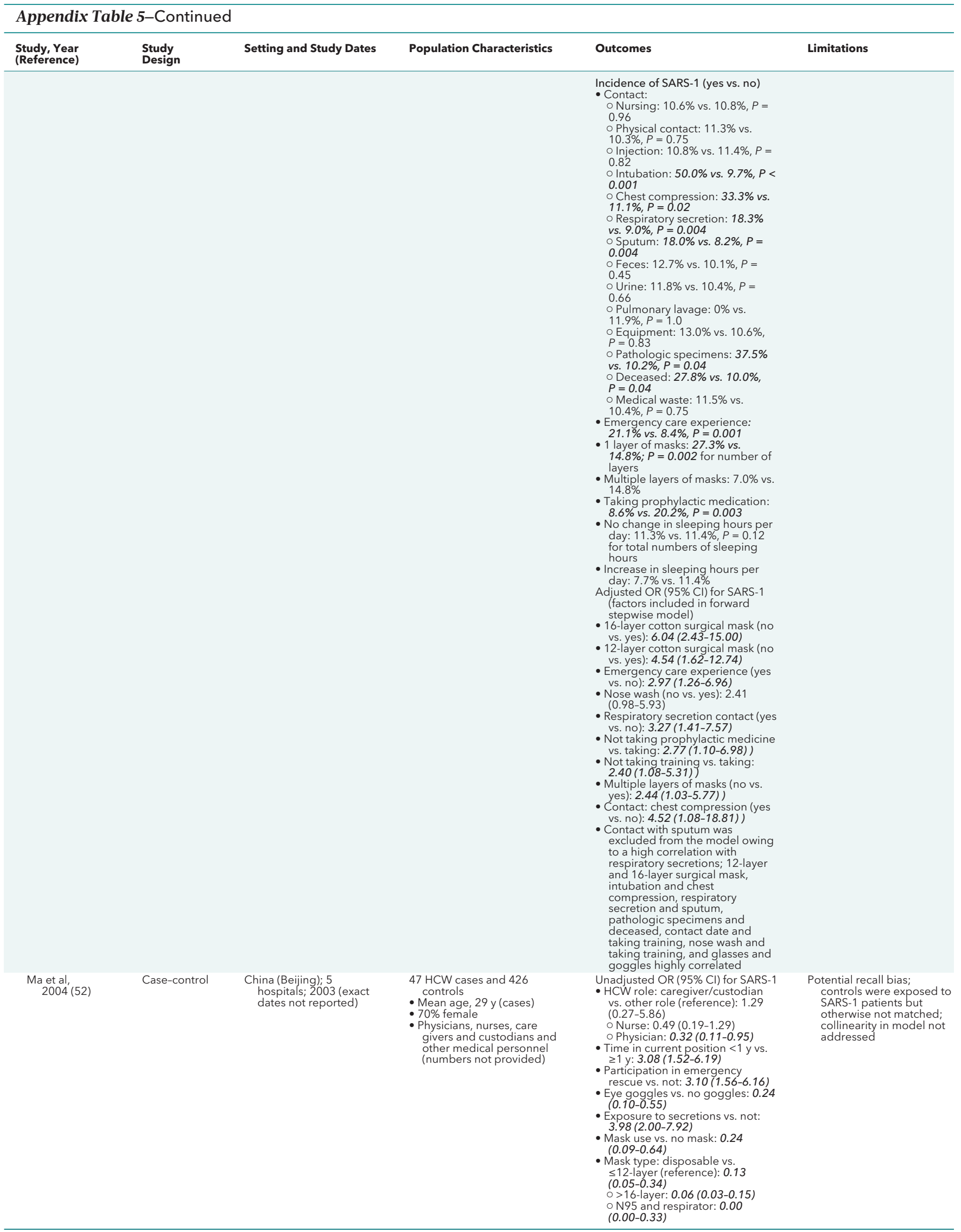

Continued on following page 


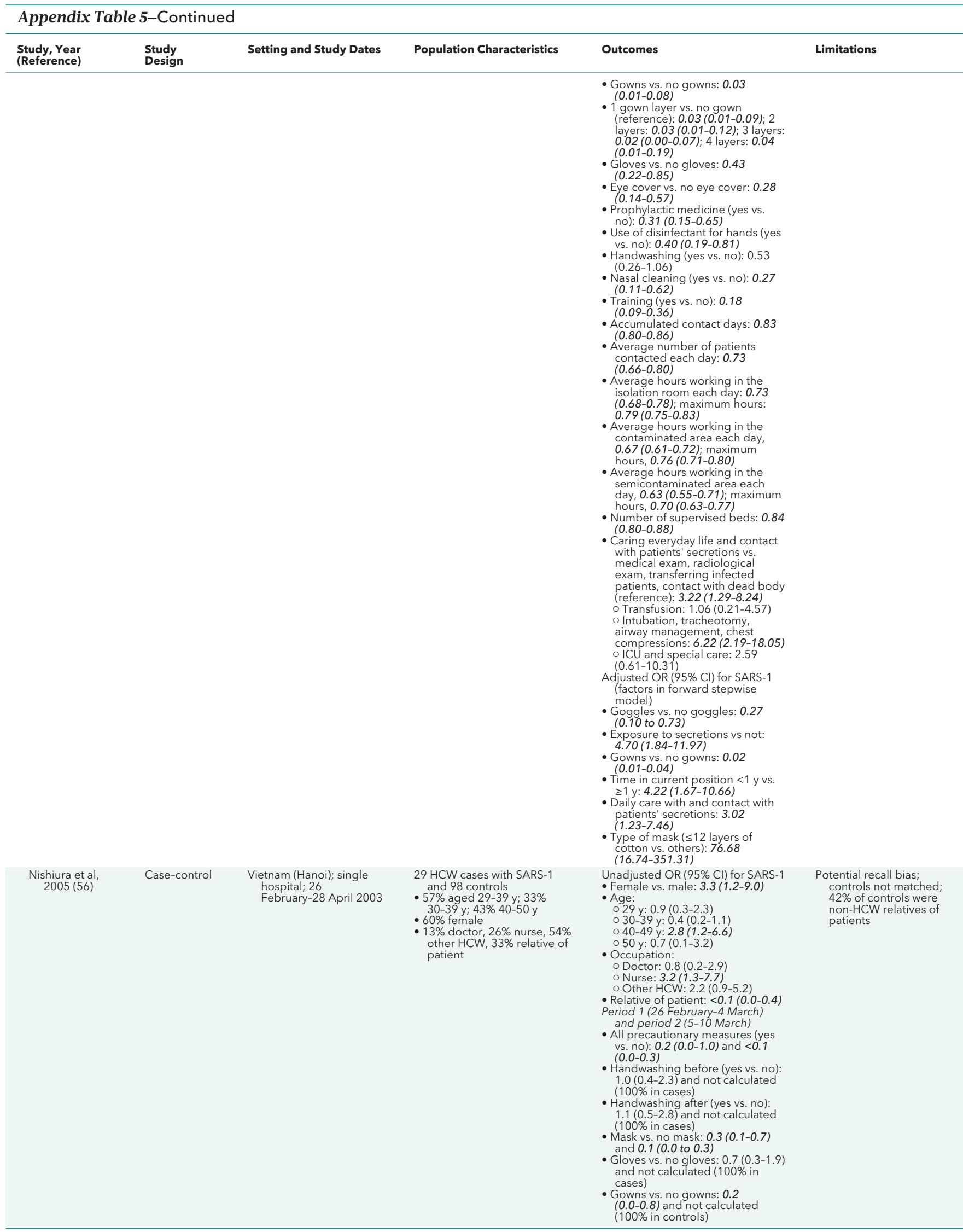

Continued on following page 


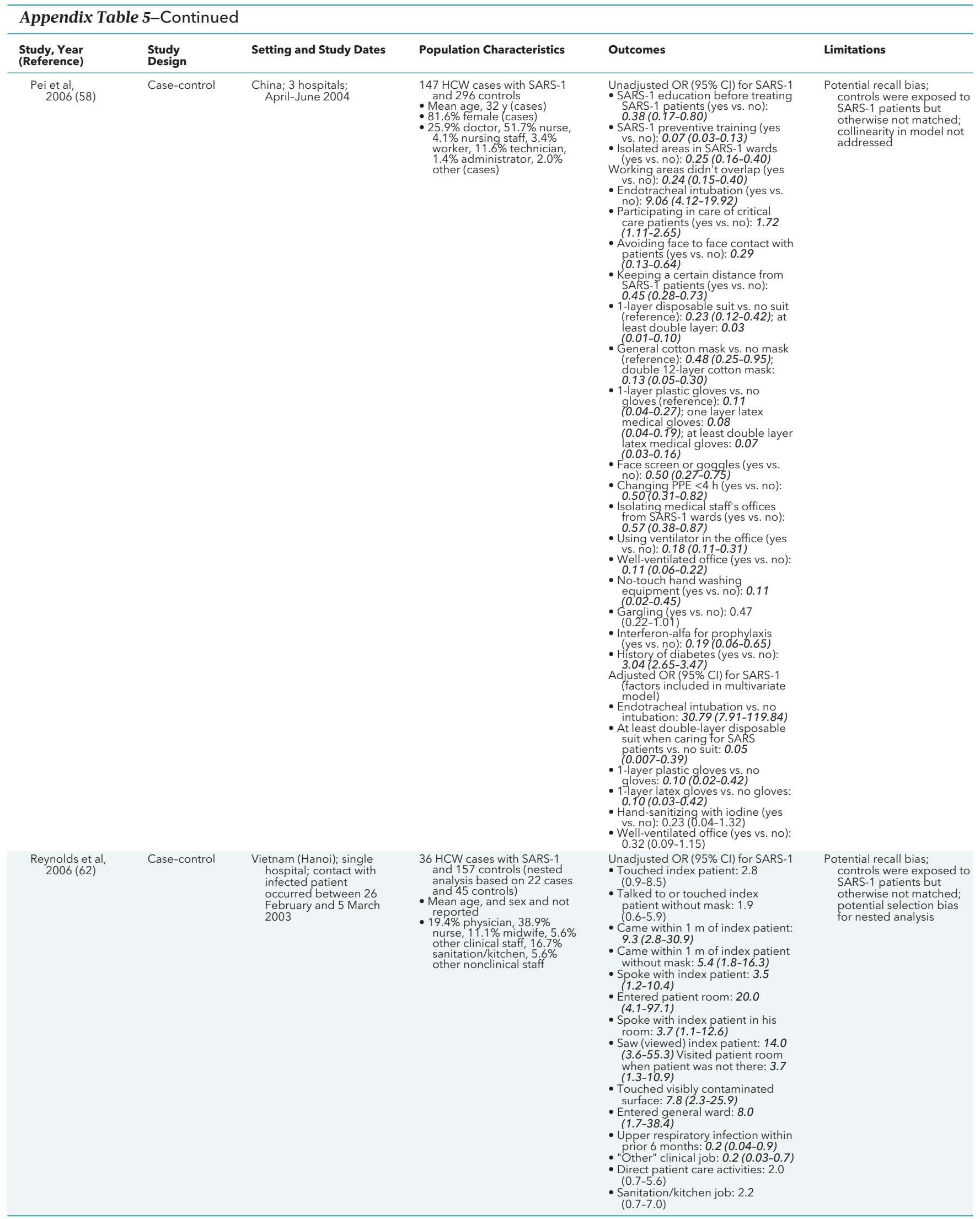

Continued on following page 


\begin{tabular}{|c|c|c|c|c|c|}
\hline \multicolumn{6}{|c|}{ Appendix Table 5-Continued } \\
\hline $\begin{array}{l}\text { Study, Year } \\
\text { (Reference) }\end{array}$ & $\begin{array}{l}\text { Study } \\
\text { Design }\end{array}$ & Setting and Study Dates & Population Characteristics & Outcomes & Limitations \\
\hline $\begin{array}{l}\text { Seto et al, } \\
2003(65)\end{array}$ & Case-control & $\begin{array}{l}\text { Hong Kong; } 5 \text { hospitals; } \\
\text { dates not reported }\end{array}$ & $\begin{array}{l}13 \text { HCW cases and } 241 \\
\text { controls } \\
\text { Age not reported } \\
\text { - } 69 \% \text { female (cases) } \\
\text { 15\% doctor, } 46 \% \text { nurse, 31\% } \\
\text { health care assistant, } 8 \% \\
\text { domestic staff (cases) }\end{array}$ & 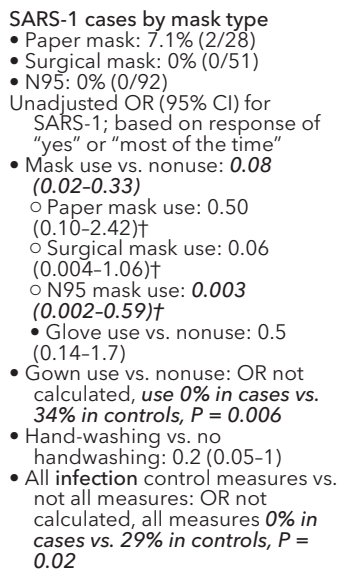 & $\begin{array}{l}\text { Potential recall bias; no } \\
\text { control for confounding; } \\
\text { controls not matched } \\
\text { other than exposure to } \\
\text { patients with SARS; } \\
\text { laboratory confirmation } \\
\text { of cases not reported }\end{array}$ \\
\hline $\begin{array}{l}\text { Teleman et al, } \\
2004(66)\end{array}$ & Case-control & $\begin{array}{l}\text { Singapore; } 1 \text { hospital; } \\
\text { 1-22 March } 2003\end{array}$ & $\begin{array}{l}36 \text { HCW cases with SARS-1 } \\
\text { and } 50 \text { controls } \\
\text { 63.9\% aged < } 30 \text { y (cases) } \\
\text { 8 } 88.9 \% \text { female (cases) } \\
\text { 72\% doctor or nurse; } 28 \% \\
\text { other HCW }\end{array}$ & 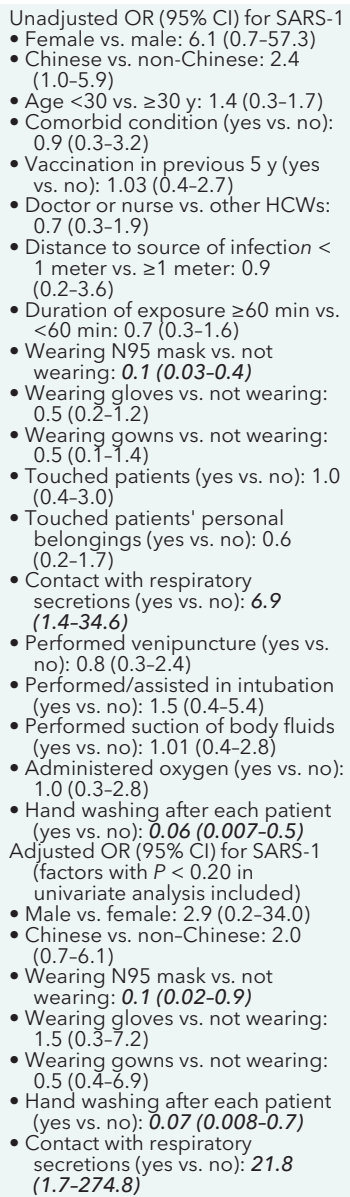 & $\begin{array}{l}\text { Potential recall bias; } \\
\text { controls not matched } \\
\text { other than exposure to } \\
\text { patients with probable } \\
\text { SARS; collinearity in } \\
\text { model not addressed }\end{array}$ \\
\hline
\end{tabular}




\begin{tabular}{|c|c|c|c|c|c|}
\hline \multicolumn{6}{|c|}{ Appendix Table 5-Continued } \\
\hline $\begin{array}{l}\text { Yen et al, } \\
\quad 2011(76)\end{array}$ & Case-control & $\begin{array}{l}\text { Taiwan; } 50 \text { hospitals; } 25 \\
\text { February-5 July } 2003\end{array}$ & $\begin{array}{l}50 \text { hospitals } \\
\text { - Cases: } 19 \text { hospitals with at } \\
\text { least } 1 \text { case of SARS-1 in } \\
\text { HCWs } \\
\text { - Controls: } 31 \text { hospitals with } \\
\text { no cases }\end{array}$ & 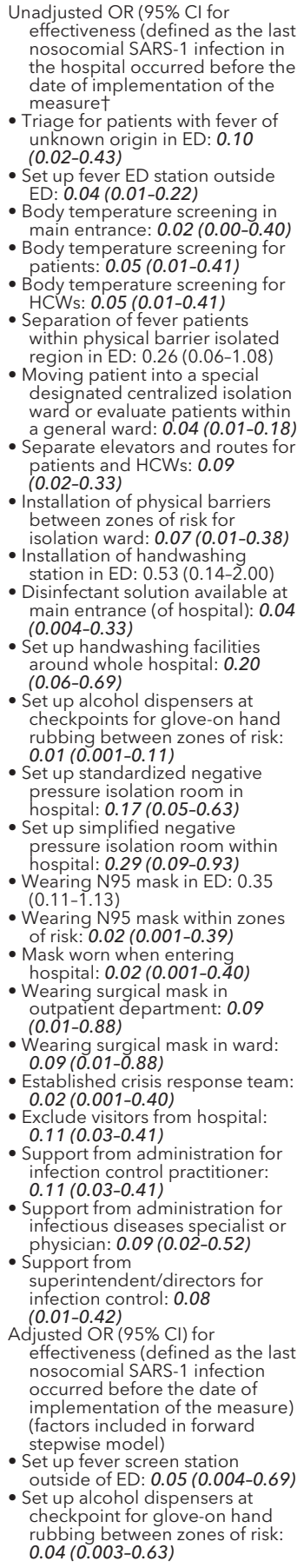 & $\begin{array}{l}\text { No control for severity of } \\
\text { outbreak across hospital; } \\
\text { unit of analysis is } \\
\text { hospitals rather than } \\
\text { HCWs; highly correlated } \\
\text { risk factors dropped from } \\
\text { model but correlated risk } \\
\text { factors not reported }\end{array}$ \\
\hline
\end{tabular}

Continued on following page 


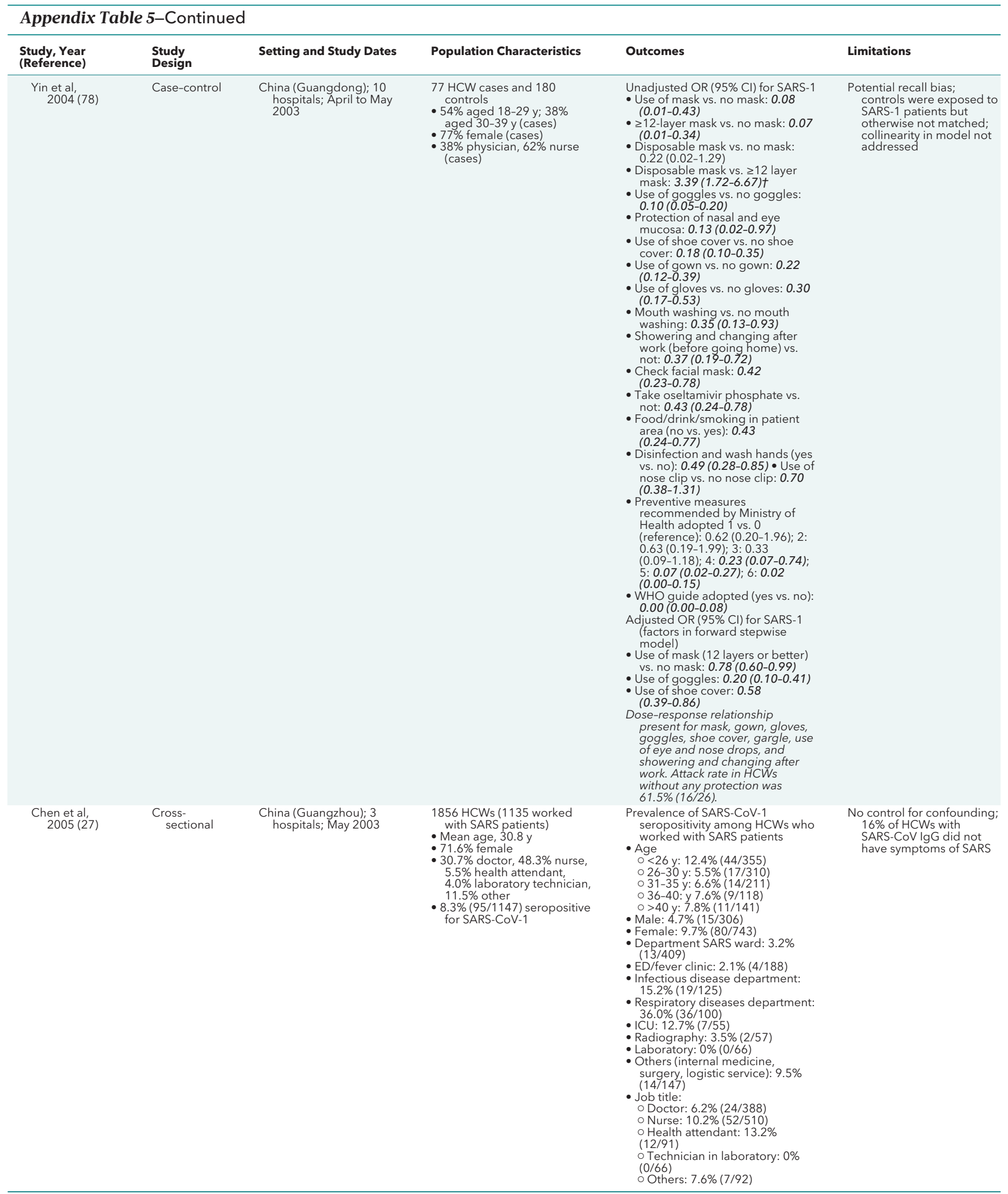

Continued on following page 


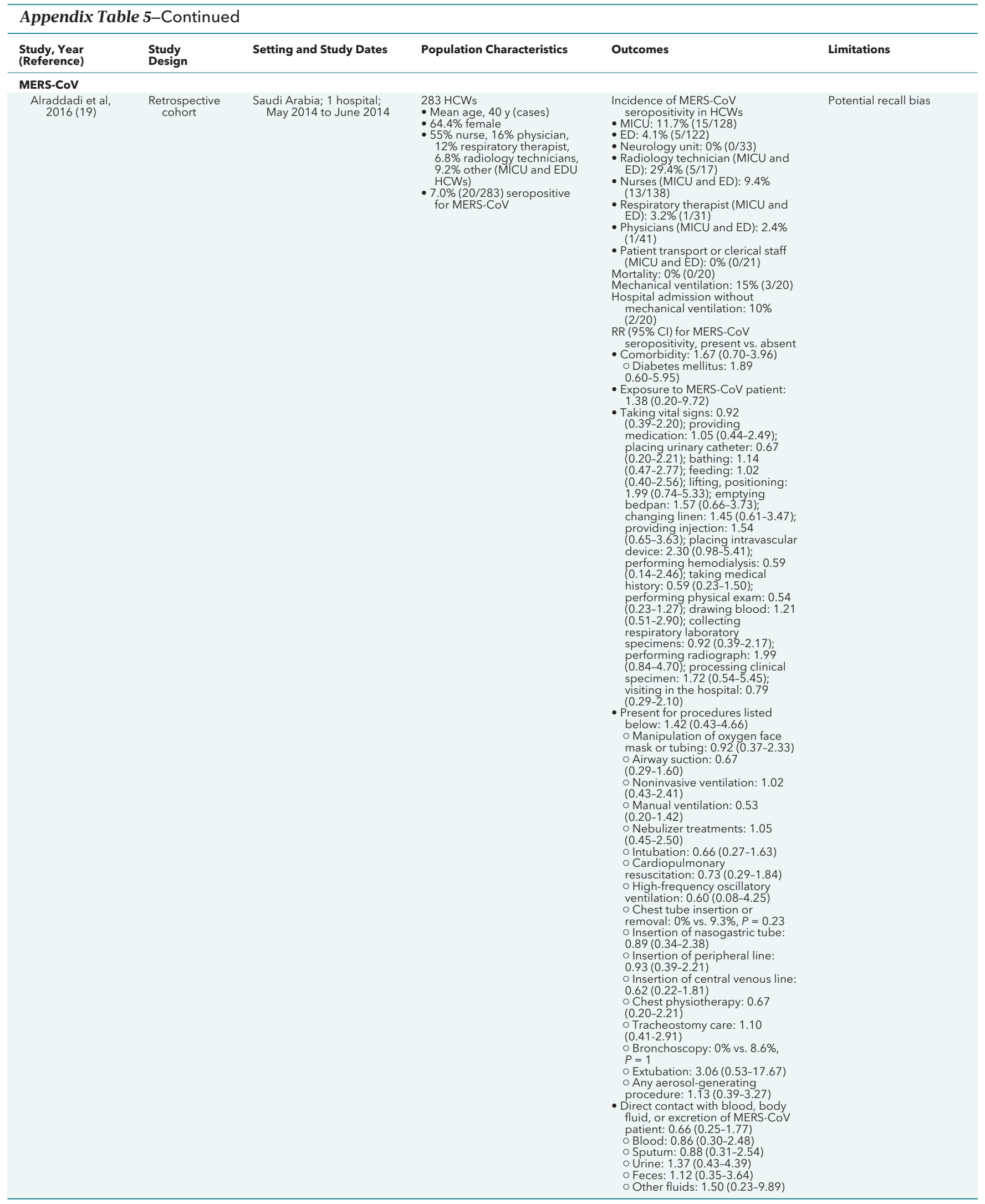

Continued on following page 


\begin{tabular}{|c|c|c|c|c|c|}
\hline \multicolumn{6}{|c|}{ Appendix Table 5-Continued } \\
\hline $\begin{array}{l}\text { Study, Year } \\
\text { (Reference) }\end{array}$ & $\begin{array}{l}\text { Study } \\
\text { Design }\end{array}$ & Setting and Study Dates & Population Characteristics & Outcomes & Limitations \\
\hline & & & & 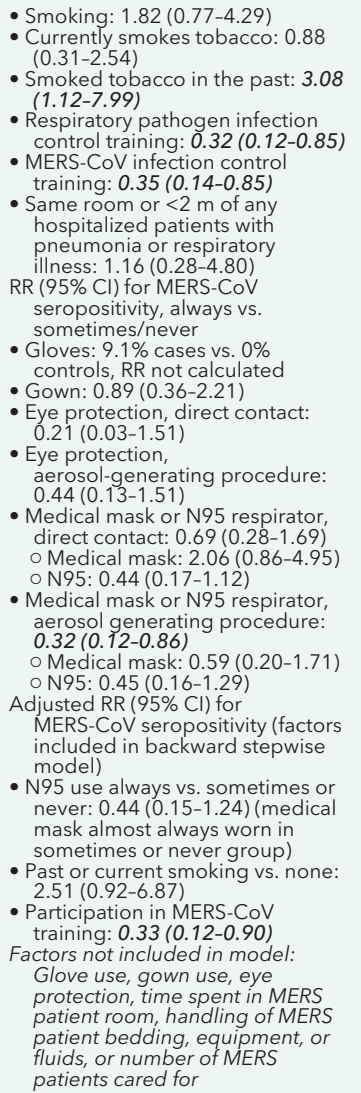 & \\
\hline
\end{tabular}

$\mathrm{APACHE}=$ Acute Physiology and Chronic Health Evaluation; CoV = coronavirus; COVID-19 = coronavirus disease 2019; CPR = cardiopulmonary resuscitation; $E C G$ = electrocardiogram; $E D=$ emergency department; ELISA = enzyme-linked immunosorbent assay; HCW = health care worker; $\| \mathrm{IFT}=$ indirect immunofluorescence test; $\mathrm{MERS}=$ Middle East respiratory syndrome; MICU = medical intensive care unit; OR = odds ratio; RR = relative risk; $P C R=$ polymerase chain reaction; PPE = personal protective equipment; SARS = severe acute respiratory syndrome; $W H O=$ World Health Organization.

* Values in boldface and italics indicate a statistically significant difference between groups.

† Unadjusted OR calculated on the basis of available data. 


\begin{tabular}{|c|c|c|c|c|c|}
\hline $\begin{array}{l}\text { Study, Year } \\
\text { (Reference) }\end{array}$ & Age & Sex & Physician & Nurse & Other HCW Role \\
\hline \multicolumn{6}{|l|}{ SARS-CoV-2 } \\
\hline $\begin{array}{l}\text { Wang et al, } \\
2020(70)\end{array}$ & - & - & - & $\begin{array}{l}\text { Nurse vs. doctor: } \\
\text { OR, } 0.04(95 \% \mathrm{Cl} \text {, } \\
0.005-0.31) \dagger\end{array}$ & $\begin{array}{l}\text { Respiratory } \\
\text { department: } 0 \% \\
\text { (0/70) } \\
\text { ICU: 0\% (0/169) } \\
\text { Infectious disease } \\
\text { department: 0\% } \\
\text { (0/39) } \\
\text { Hepatobiliary and } \\
\text { pancreatic surgery } \\
\text { department: 11\% } \\
\text { (8/74) } \\
\text { Trauma and } \\
\text { microsurgery } \\
\text { department: } 2 \% \\
(1 / 44) \\
\text { Urology } \\
\text { department: } 1 \% \\
(1 / 97)\end{array}$ \\
\hline \multicolumn{6}{|l|}{ SARS-CoV-1 } \\
\hline $\begin{array}{r}\text { Chang et al, } \\
2004(25)\end{array}$ & $\begin{array}{c}\text { Adjusted OR, } 0.97 \\
(95 \% \mathrm{Cl} \\
0.90-1.03)\end{array}$ & - & $6.1 \%(2 / 33)$ & $3.2 \%(3 / 95)$ & $\begin{array}{l}\text { Ambulance drivers: } \\
\text { 16.7\% (1/6) } \\
\text { Sanitation workers: } \\
\text { 15.4\% }(2 / 13) \\
\text { Clerks: } 6.3 \%(1 / 16) \\
\text { Administrative } \\
\text { personnel: } 0 \% \\
\text { (0/24) } \\
\text { Radiology } \\
\text { technician: } 0 \% \\
(0 / 17)\end{array}$ \\
\hline $\begin{array}{l}\text { Fowler et al, } \\
2004 \text { (30) }\end{array}$ & - & - & $16.7 \%(3 / 18)$ & $7.6 \%(5 / 66)$ & $\begin{array}{l}\text { Respiratory } \\
\text { therapist: } 11.1 \% \\
(2 / 18)\end{array}$ \\
\hline $\begin{array}{l}\text { Ho et al, } \\
2003 \text { (32) }\end{array}$ & - & - & $5.1 \%(7 / 138)$ & $3.8 \%(19 / 500)$ & $\begin{array}{l}\text { Health care } \\
\text { assistant: } 7.9 \% \\
(10 / 126) \\
\text { Cleaner: } 1.9 \% \\
(3 / 158) \\
\text { Clerical staff: } 0.8 \% \\
(1 / 131)\end{array}$ \\
\hline Ip et al, 2004 (34) & - & - & $2.4 \%(2 / 85)$ & $11.6 \%(38 / 328)$ & $\begin{array}{l}\text { Allied health: } 0.9 \% \\
(1 / 114) \\
\text { Health care/general } \\
\text { service assistants: } \\
11.8 \%(12 / 102) \\
\text { Ancillary: } 0 \%(0 / 113) \\
\text { Other: } 0 \%(0 / 12)\end{array}$ \\
\hline $\begin{array}{l}\text { Lau et al, } \\
2004 \text { (43) }\end{array}$ & - & - & - & $1.07 \%$ (SD 1.38) & $\begin{array}{l}\text { Nonmedical support } \\
\text { staff: } 2.34 \% \text { (SD } \\
3.43 \text { ) } \\
\text { Other technical and } \\
\text { medical staff: } \\
0.32 \% \text { (SD 0.49); }\end{array}$ \\
\hline Li et al, 2003 (45) & - & - & $2.88 \%$ & $4.78 \%$ & $\begin{array}{l}\text { Nursing assistant: } \\
6.67 \% \\
\text { Other hospital staff: } \\
0 \%\end{array}$ \\
\hline
\end{tabular}




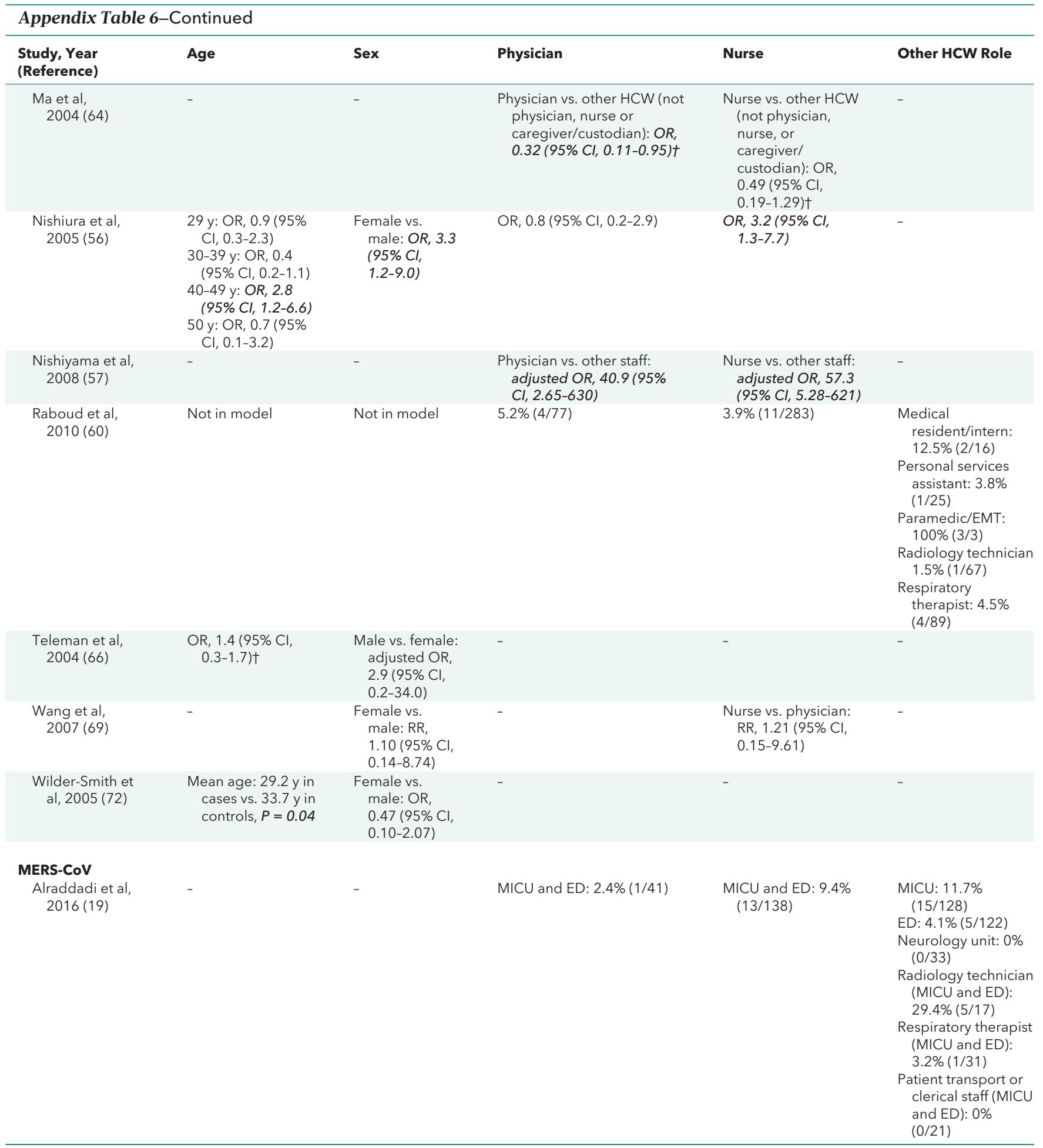

$\mathrm{ED}=$ emergency department; $\mathrm{EMT}=$ emergency medical technician; ICU = intensive care unit; $\mathrm{HCW}=$ health care worker; $\mathrm{MICU}=$ medical intensive care unit; $\mathrm{OR}=$ odds ratio; $\mathrm{RR}=$ relative risk.

* Values in boldface and italics indicate a statistically significant difference between groups.

† Variable not included in a multivariate model. 


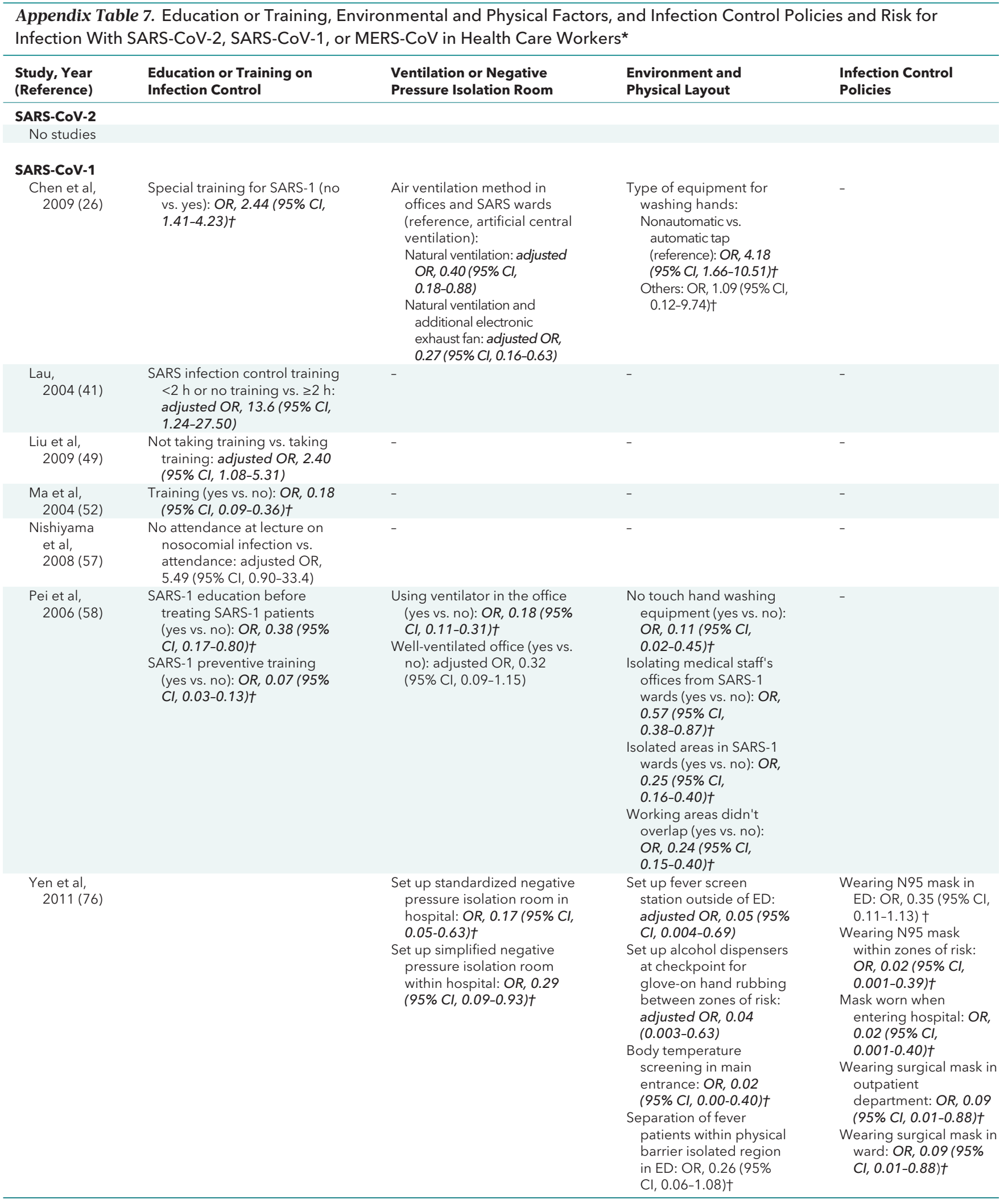




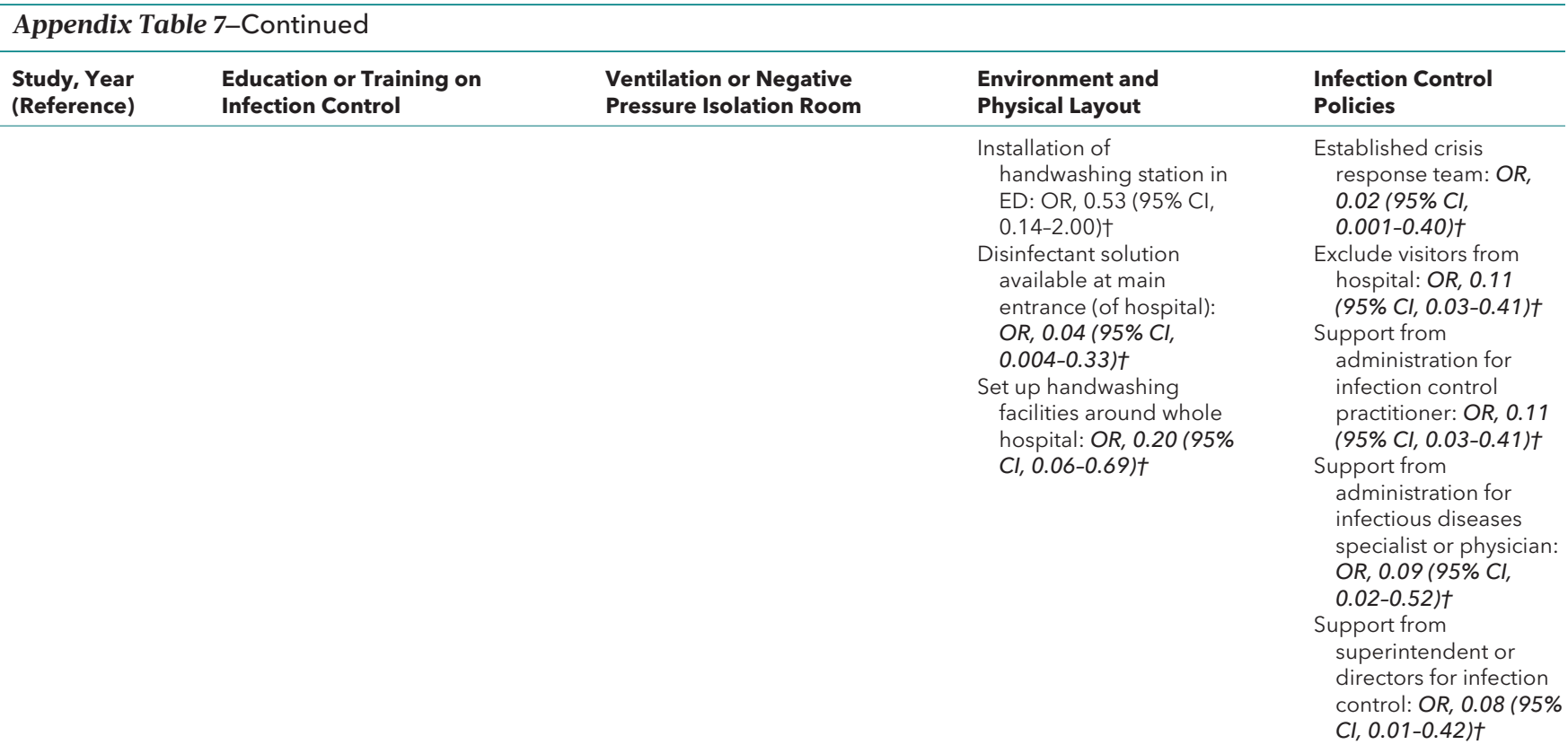

\section{MERS-CoV}

Alraddadi Participation in MERS-CoV

et al, training: $R R, 0.33(95 \% \mathrm{Cl}$

2016 (19) $0.12-0.90)$

$\mathrm{AOR}=$ adjusted odds ratio; $\mathrm{CoV}=$ coronavirus; $\mathrm{ED}=$ emergency department; $\mathrm{MERS}=$ Middle East respiratory syndrome; OR = odds ratio; $\mathrm{RR}=$ relative risk; SARS = severe acute respiratory syndrome.

* Values in boldface and italics indicate a statistically significant difference between groups.

† Variable not included in a multivariate model. 